UNIVERSIDADE DE BRASÍLIA

INSTITUTO DE GEOCIÊNCIAS

PROGRAMA DE PESQUISA E PÓS-GRADUAÇÃO EM GEOLOGIA UnB

MODELO DE VELOCIDADE SÍSMICA DE ONDAS P DA CROSTA E MANTO SUPERIOR AO LONGO DO PERFIL PABBRISE, ESTADO DE SÃO PAULO

\author{
Renato Borges Bernardes \\ DISSERTAÇÃO DE MESTRADO \\ $\mathrm{N}^{\mathrm{o}} 357$
}

Reinhardt A. Fuck

Orientador

José Eduardo P. Soares

Coorientador

Brasília - DF

2015 
UNIVERSIDADE DE BRASÍLIA

INSTITUTO DE GEOCIÊNCIAS

PROGRAMA DE PESQUISA E PÓS-GRADUAÇÃO EM GEOLOGIA UnB

\section{MODELO DE VELOCIDADE SÍSMICA DE ONDAS P DA CROSTA E MANTO SUPERIOR AO LONGO DO PERFIL PABBRISE, ESTADO DE SÃO PAULO}

\section{Renato Borges Bernardes}

Dissertação de Mestrado

$\mathrm{N}^{\mathrm{o}} 357$

Área de concentração: Geologia Regional

Orientador: Prof. Dr. Reinhardt Adolfo Fuck - UnB

Coorientador: Prof. Dr. José Eduardo Pereira Soares - UnB

Banca Examinadora:

Prof $^{\mathrm{a}}$. Dr ${ }^{\mathrm{a}}$. Adalene Moreira Silva - UnB

Prof. Dr. Miguel Antônio Tupinambá Araújo Souza - UERJ

Prof. Dr. Reinhardt Adolfo Fuck - UnB 
"Do not go where the path may lead, go instead where there is no path and leave a trail." - Ralph Waldo Emerson

"No unhallowed breath shall seal a fate before me."

- Agalloch 


\section{AGRADECIMENTOS}

Aos meus pais, Carlos Alberto e Cleony, e a meu irmão, Eduardo, pela compreensão e apoio incondicionais desde o início de tudo, em especial, de minha jornada geológica em 2007. Muito obrigado!

À Cássia pela (extrema) paciência e pela partilha, tanto dos momentos alegres, quanto dos de provação ao longo de nossa caminhada.

Aos meus tios, Gaspar e Cleópatra, e primos, Ana Flávia, Luiz Roberto e Luís Felipe, por terem sido minha segunda família em Brasília.

Aos meus orientadores, professores Reinhardt A. Fuck e José Eduardo P. Soares, pela prontidão, ensinamentos, correções, discussões e descobertas sísmicas e geológicas no decorrer destes anos.

Ao professor Marcus Vinícius A. G. de Lima (UNIPAMPA) por parte do processamento dos dados adquiridos em campo e suporte na utilização de programas complementares.

À professora Adriana C. Carmelo, e aos alunos Darbý e Elianara, pelo processamento e disponibilização dos perfis de métodos potenciais aqui utilizados.

Aos professores Adriana C. Carmelo, Ícaro Vitorello, José Oswaldo de Araújo Filho, Miguel Tupinambá, Mônica Heilbron, Peter C. Hackspacher e Randell Stephenson pelas discussões em campo e/ou laboratório.

Ao professor Carlos Jorge de Abreu pelo suporte com a impressão das seções sísmicas.

Aos colegas do LabLitos/UnB e da pós-graduação pelas discussões geológicas e momentos de descontração.

A todos os participantes do trabalho de campo para a realização do perfil sísmico PABBRISE. Em especial ao corpo técnico-científico do IG/UnB (Marcos Marcilo e Péricles), do IAG/USP (Irfan Ullah, Cristóvão, Luiz Galhardo e Sérgio 'Bob’), do INPE ('Lilico' e Isac) e do IGCE/UNESP-Rio Claro.

Aos proprietários de terra que permitiram que as explosões controladas e estações triaxiais fossem, respectivamente, realizadas e instaladas em suas propriedades.

À Petrobras pelo financiamento do projeto de pesquisa intitulado "Estudo da Transição da Crosta Continental-Crosta Oceânica na Região Sudeste do Brasil: Experimentos de Refração Sísmica Profunda e Magnetotelúrico e Estudos Geológicos na Faixa Ribeira e Bacia do Paraná - Transecta Refração (PETROBRAS/UnB - 2012/05132)", e cuja presente dissertação representa uma pequena parte. 


\section{SUMÁRIO}

Lista de figuras .i

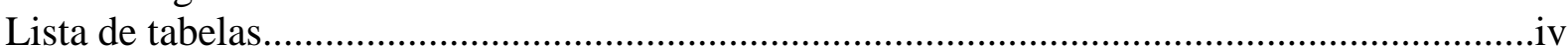

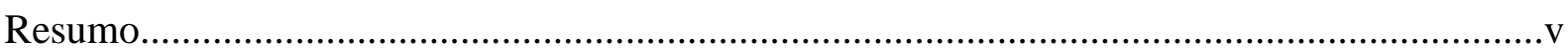

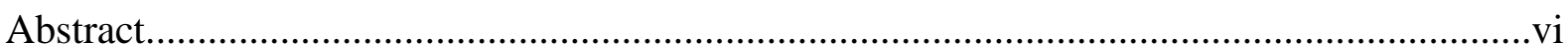

1. INTRODUÇÃ̃____

2. CONTEXTO TECTÔNICO DA REGIÃO EM ESTUDO__

2.1. Faixa Brasília meridional: Nappe Socorro-Guaxupé......................................4



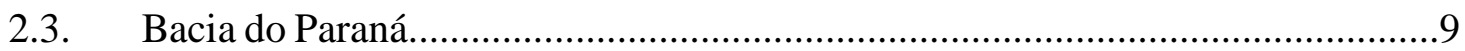

2.4. Sistema de Riftes Cenozóicos do Sudeste do Brasil...........................................16

2.4.1. Origem e evolução estrutural................................................................16

2.4.2. Graben de Taubaté.............................................................................20

3. FUNDAMENTAÇÃO TEÓRICA DOS MÉTODOS UTILIZADOS _ 22

3.1. O método sísmico de refração/reflexão de ângulo amplo (WARR)..................22

3.2. O traçado de raios por meio do pacote de programas RAYINVR .......................27

4. AQUISIÇÃO E PROCESSAMENTO DOS DADOS_ 31

4.1. Aquisição dos dados: o experimento sísmico...................................................31

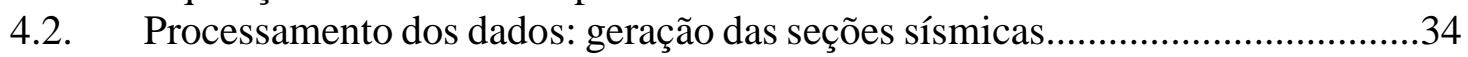

5. ANÁLISE DAS SEÇÕES SÍSMICAS E MODELAGEM DIRETA__ 40

5.1. Identificação e leitura dos alinhamentos de fases sísmicas...............................40

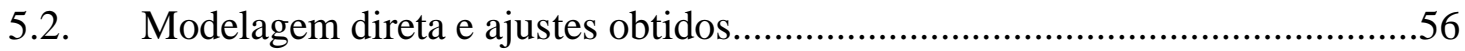

6. O MODELO SÍSMICO: RESULTADOS E DISCUSSÕES___

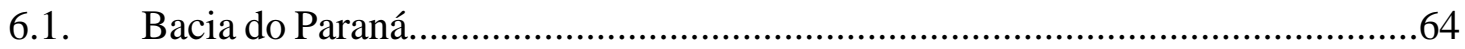

6.2. Estrutura de velocidade da crosta continental.................................................65

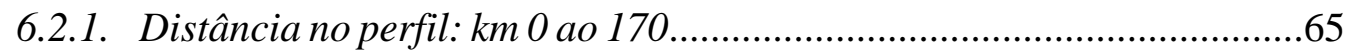

6.2.2. Distância no perfil: $\mathrm{km} 170$ ao 525 ......................................................66

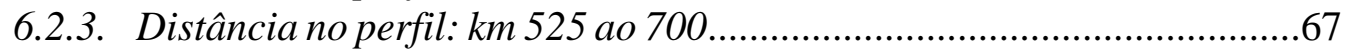

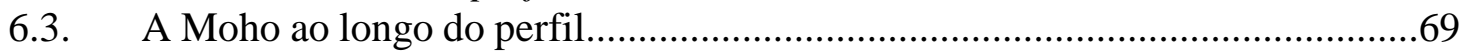

6.4. Estrutura de velocidade do manto superior......................................................74

6.5. Considerações sobre a evolução da Bacia do Paraná e da margem continental

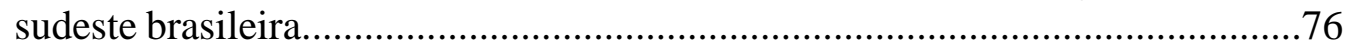

7. CONCLUSÕES _ 82

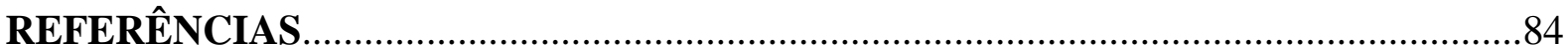




\section{LISTA DE FIGURAS}

Figura 1.1 Mapa de relevo com a localização do perfil sísmico PABBRISE

Figura 2.1 Mapa tectônico simplificado da região em estudo (modificado de Heilbron et al., 2004; Perrotta et al., 2005; Peternel et al., 2005 e Trouw et al., 2013).

Figura 2.2 Curvas de subsidências total e backstripped para o poço 3-CB-3-SP e que retratam os três principais estágios de subsidência identificados por Oliveira (1987) (adaptado de Zalán et al., 1990).

Figura 2.3 Propostas de arcabouço tectônico para o embasamento da Bacia do Paraná na região em estudo. Adaptado de: a) Cordani et al. (1984), b) Milani \& Ramos (1998) e, c) Mantovani et al. (2005)

Figura 2.4 O Sistema de Riftes Cenozóicos do Sudeste do Brasil como interpretado por Zalán \& Oliveira (2005).

Figura 3.1 Sismograma hipotético mostrando as relações das curvas tempo-distância entre as ondas direta, refratada e refletida para um modelo de uma interface.

Figura 3.2 A distribuição de velocidade $v(x, z)$, dada pela equação (3.8) dentro de um trapezoide de modelo hipotético parametrizado (adaptado de Zelt \& Smith, 1992). 28

Figura 4.1 Ilustração dos alinhamentos de fases das ondas direta, refratada e refletida antes e após a aplicação da velocidade de redução, $v_{R}$ (adaptado de Shearer, 2009) .36

Figura 4.2 Seções sísmicas finais dos componentes verticais para ondas P dos pontos de tiro PT-01-07 geradas após todos os procedimentos de processamento.

Figura 4.3 Seções sísmicas finais dos componentes verticais para ondas P dos pontos de tiro PT-08-11, 13 e 15, geradas após todos os procedimentos de processamento......

Figura 5.1 Representação esquemático-teórica de curvas distância-tempo (alinhamentos de fases sísmicas) Psed, Pg, PiP, Pi, PmP, Pn geradas pelo RAYINVR.

Figura 5.2 Seção sísmica traço-normalizada dos componentes verticais para ondas P do ponto de tiro PT01 e os ajustes obtidos na modelagem. A seção sísmica foi filtrada na banda passante 1-10 Hz. A velocidade de redução é $\mathrm{km} / \mathrm{s}$. 43

Figura 5.3 Seção sísmica traço-normalizada dos componentes verticais para ondas P do ponto de tiro PT02 e os ajustes obtidos na modelagem. A seção sísmica foi filtrada na banda passante 1-10 Hz. A velocidade de redução $\quad$ é de $\quad 8,0$

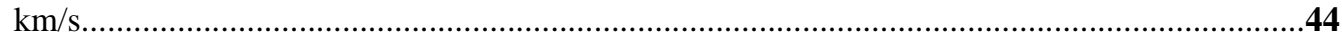

Figura 5.4 Seção sísmica traço-normalizada dos componentes verticais para ondas P do ponto de tiro PT03 e os ajustes obtidos na modelagem. A seção sísmica foi filtrada na banda passante 1-10 Hz. A velocidade de redução $\quad$ é de $\quad 8,0$

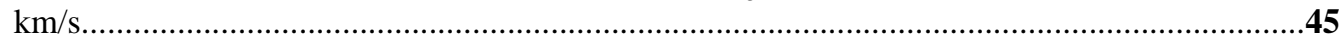

Figura 5.5 Seção sísmica traço-normalizada dos componentes verticais para ondas P do ponto de tiro PT04 e os ajustes obtidos na modelagem. A seção sísmica foi filtrada na banda passante 1-10 Hz.

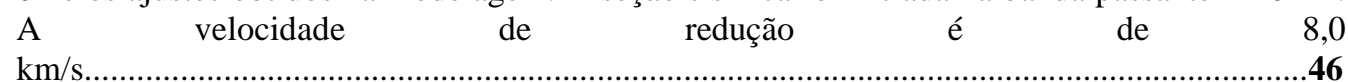


Figura 5.6 Seção sísmica traço-normalizada dos componentes verticais para ondas P do ponto de tiro PT05 e os ajustes obtidos na modelagem. A seção sísmica foi filtrada na banda passante 1-10 Hz. A velocidade de redução é de $\mathrm{km} / \mathrm{s}$. 47

Figura 5.7 Seção sísmica traço-normalizada dos componentes verticais para ondas P do ponto de tiro PT06 e os ajustes obtidos na modelagem. A seção sísmica foi filtrada na banda passante 1-10 Hz. A velocidade de redução é

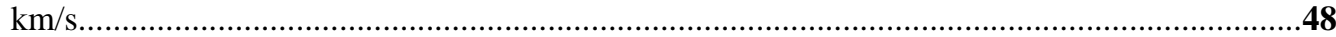

Figura 5.8 Seção sísmica traço-normalizada dos componentes verticais para ondas P do ponto de tiro PT07 e os ajustes obtidos na modelagem. A seção sísmica foi filtrada na banda passante 1-10 Hz.
A velocidade
de redução
é de
de 8,0

$\mathrm{km} / \mathrm{s}$.

49

Figura 5.9 Seção sísmica traço-normalizada dos componentes verticais para ondas P do ponto de tiro PT08 e os ajustes obtidos na modelagem. A seção sísmica foi filtrada na banda passante 1-10 Hz.

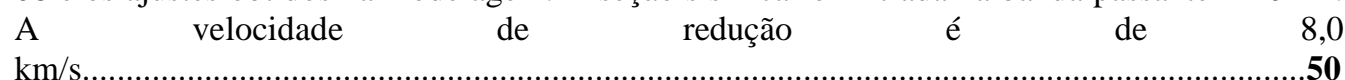

Figura 5.10 Seção sísmica traço-normalizada dos componentes verticais para ondas $\mathrm{P}$ do ponto de tiro PT09 e os ajustes obtidos na modelagem. A seção sísmica foi filtrada na banda passante 1-10 Hz. A velocidade de redução é $\mathrm{km} / \mathrm{s}$. 51

Figura 5.11 Seção sísmica traço-normalizada dos componentes verticais para ondas P do ponto de tiro PT10 e os ajustes obtidos na modelagem. A seção sísmica foi filtrada na banda passante 1-10 Hz. A velocidade de redução $\quad$ é de $\quad 8,0$

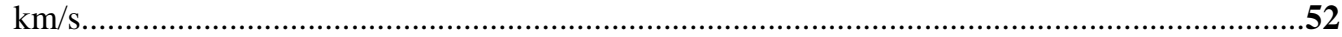

Figura 5.12 Seção sísmica traço-normalizada dos componentes verticais para ondas P do ponto de tiro PT11 e os ajustes obtidos na modelagem. A seção sísmica foi filtrada na banda passante 1-10 Hz. A velocidade de redução é

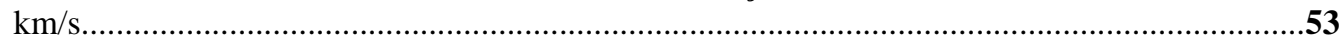

Figura 5.13 Seção sísmica traço-normalizada dos componentes verticais para ondas P do ponto de tiro PT13 e os ajustes obtidos na modelagem. A seção sísmica foi filtrada na banda passante 1-10 Hz.

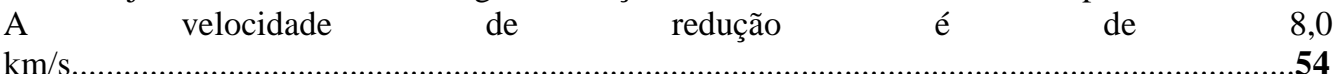

Figura 5.14 Seção sísmica traço-normalizada dos componentes verticais para ondas P do ponto de tiro PT15 e os ajustes obtidos na modelagem. A seção sísmica foi filtrada na banda passante 1-10 Hz. A velocidade de redução é $\mathrm{km} / \mathrm{s}$ 55

Figura 5.15 Detalhe dos ajustes obtidos para todos os alinhamentos de fase Psed nas camadas da Bacia do Paraná: derrames basálticos e rochas sedimentares pré-vulcânicas...........................................57

Figura 5.16 Detalhe dos ajustes obtidos para os alinhamentos de fase Pg (crosta superior)........................58

Figura 5.17 Detalhe dos ajustes obtidos para os alinhamentos de fase Pi lidos (topo da crosta inferior)

Figura 6.1 Modelo bidimensional de velocidade sísmica de ondas P para a crosta e manto superior derivado por modelagem direta do traçado de raios por meio do pacote de programas RAYINVR/vmed (Zelt \& Smith, 1992) ao longo do perfil PABBRISE. a) Enfoque na porção superior do modelo. Exagero vertical (e.v.) de $\sim 20: 1$. b) O modelo completo. Exagero vertical (e.v.) de $\sim 2,5: 1$ 
Figura 6.2 Modelo sísmico apresentado em linhas de isovelocidade (diagrama inferior) acompanhado de topografia (ETOPO1 - Amante \& Eakins, 2009) (diagrama intermediário), e anomalia Bouguer (WGM2012 - Bonvalot et al., 2012) e campo magnético anômalo - CMA (EMAG2 - Maus, 2009) (diagrama superior) obtidos, principalmente, a partir de sensores orbitais... 63

Figura 6.3 Detalhe da seção sísmica PT-01 equivalente ao espaço entre o topo (reflexão PiP) e a base (reflexão PmP) da crosta inferior.

Figura 6.4 Detalhe da seção sísmica PT-04 (para noroeste) equivalente ao espaço entre a base da crosta (Moho, reflexão PmP) e o topo do manto litosférico (pelo menos três reverberações coerentes pós-PmP).

Figura 6.5 Detalhe da seção sísmica PT-07 (para noroeste) equivalente à região do limite crosta-manto sísmico (a Moho, fases PmP)...

Figura 6.6 Heterogeneidade e complexidade do limite crosta-manto sísmico como observado e modelado por Enderle et al. (1997)

Figura 6.7 Detalhe da seção sísmica PT-11 (para sudeste) equivalente à região do limite crosta-manto sísmico (a Moho, fases PmP). A Moho se mostra como "clássica" descontinuidade de primeira ordem, não havendo reverberações significativas antes nem depois do alinhamento de fases PmP.

Figura 6.8 Comparação das profundidades obtidas para a descontinuidade de Moho (em km) entre o método sísmico de refração/reflexão de ângulo amplo (WARR - linha vermelha; este trabalho) e o método da função do receptor (FR - linha preta tracejada; Peixoto, 2015) (gráfico superior)

Figura 6.9 Interpretação tectônica simplificada da estrutura crustal e topo do manto superior ao longo da extensão combinada onshore-offshore $(1620 \mathrm{~km})$ entre os perfis sísmicos PABBRISE (este trabalho) e SB01 (Evain et al., 2015). A região do necking marca afinamento crustal abrupto. Abreviações: BT - Bacia de Taubaté; SM - Serra do Mar; MLPN - Manto Litosférico Paraná Norte; MLMS - Manto Litosférico Margem Sudeste. Exagero vertical (e.v.) de $\sim 7,5: 1$ 


\section{LISTA DE TABELAS}

Tabela 4.1 Localização e parâmetros das fontes explosivas utilizadas ao longo do perfil PABBRISE..

Tabela 6.1 Resumo dos parâmetros do modelo sísmico PABBRISE obtido a partir de modelagem direta do tempo de trânsito das ondas P por meio do pacote de programas RAYINVR/vmed (Zelt \& Smith, 1992).

61

Tabela 6.2 Comparação entre as profundidades da Moho ao longo do perfil obtidas por Peixoto (2015) e este trabalho. Os valores de Vp média crustal fornecidos pelo método WARR foram utilizados por Peixoto (2015) para a obtenção da profundidade da Moho por função do receptor...... 


\section{RESUMO}

BERNARDES, R.B. 2015. Modelo de velocidade sísmica de ondas P da crosta e manto superior ao longo do perfil PABBRISE, Estado de São Paulo. Dissertação (Mestrado em Geologia) - Instituto de Geociências, Universidade de Brasília, Brasília. 92 p.

O perfil PABBRISE consiste em experimento sísmico de refração/reflexão de ângulo amplo realizado no Estado de São Paulo. O perfil possui aproximadamente $700 \mathrm{~km}$ de extensão e atravessa a porção nordeste da Bacia do Paraná, passando por parte da Faixa Brasília meridional (Nappe Socorro), até a margem continental adjacente (Faixa Ribeira central).

A modelagem do tempo de trânsito das ondas $\mathrm{P}$ resultou em modelo sísmico em que a descontinuidade de Mohorovičić é estruturada e heterogênea, com profundidades entre 32,0 e $43,5 \mathrm{~km}$, sendo mais rasa próximo à margem continental.

A geometria obtida possibilitou a segmentação da crosta continental em três domínios sísmicos. Em todos os domínios a crosta inferior foi modificada, hora por intrusões máficas, estiramento dúctil localizado ou delaminação. Próximo ao Rio Paraná (km 0-170 do perfil) a crosta inferior $(\mathrm{Vp}=6,70-7,05 \mathrm{~km} / \mathrm{s})$ mostra reverberações sísmicas descontínuas. Essas indicam que parte dessa crosta foi intrudida por corpos máficos tabulares. No domínio central ( $\mathrm{km} \mathrm{170-525)} \mathrm{a} \mathrm{crosta} \mathrm{superior} \mathrm{chega} \mathrm{a} \mathrm{ser} \mathrm{quase} \mathrm{três} \mathrm{vezes} \mathrm{mais} \mathrm{espessa} \mathrm{do} \mathrm{que} \mathrm{a} \mathrm{inferior,} \mathrm{com}$ a crosta inferior associada a um forte gradiente positivo de velocidade. Este interpretado como underplating máfico na base da crosta $(\mathrm{Vp}=7,10-7,25 \mathrm{~km} / \mathrm{s})$. A crosta inferior próximo à margem continental $(\mathrm{km} 525-700)$ mostra velocidades anomalamente baixas $(\mathrm{Vp}=6,48-6,65$ $\mathrm{km} / \mathrm{s}$ ) que, quando associadas às proeminentes elevações das serras do Mar e da Mantiqueira, à espessura crustal de 32 km e à anomalia gravimétrica Bouguer, sugerem que a porção máfica da crosta inferior tenha sido delaminada por processo geodinâmico desencadeado pela abertura do Oceano Atlântico Sul. A delaminação foi seguida por soerguimento flexural regional e proeminente magmatismo alcalino, e ajudou a moldar o que hoje é a atual borda nordeste da Bacia do Paraná.

$\mathrm{O}$ topo do manto superior mostra $\mathrm{Vp}=7,88-7,92 \mathrm{~km} / \mathrm{s}$, próximo à margem continental (porção SE do perfil), e $\mathrm{Vp}=8,25 \mathrm{~km} / \mathrm{s}$ sob a bacia (porção $\mathrm{NW}$ do perfil). Isso revela que esses dois domínios de manto litosférico possuem origens e evoluções distintas. 


\begin{abstract}
BERNARDES, R.B. 2015. P-wave seismic velocity model of the crust and upper mantle along the PABBRISE profile, São Paulo State. Dissertation (M.Sc. in Geology) - Institute of Geosciences, University of Brasilia, Brasilia. 92 p.
\end{abstract}

The PABBRISE profile consists of a $c a$. $700-\mathrm{km}$ wide-angle reflection/refraction seismic experiment carried out in the São Paulo State. The profile crosses the northeast part of the Paraná Basin, the southernmost part of the Brasilia fold belt (the Socorro nappe), and ends on the adjacent continental margin, which comprises the central Ribeira fold belt.

Modelling of the P-wave travel-times provided a seismic model in which the Mohorovičić discontinuity is shown as a structured and heterogeneous interface, with depths between 32.0 and $43.5 \mathrm{~km}$, getting shallower to the southeast, near the continental margin.

The obtained geometry allowed the segmentation of the continental crust in three different seismic domains. In all of the domains the lower crust has been modified in some way: by mafic intrusions, localized ductile stretching or delamination. Near the Paraná River (profile distance $\mathrm{km} \mathrm{0-170)}$ the lower crust $(\mathrm{Vp}=6.70-7.05 \mathrm{~km} / \mathrm{s})$ shows discontinuous seismic reverberations. These indicates that tabular mafic bodies (i.e. sills) intruded parts of this crust. In the central domain (profile distance km 170-525) the upper crust is almost three times thicker than the lower crust. The latter is associated with a strong positive velocity gradient, interpreted as mafic underplating at the base of the crust $(\mathrm{Vp}=7.10-7.25 \mathrm{~km} / \mathrm{s})$. The lower crust near the continental margin (profile distance $\mathrm{km} 525-700)$ shows anomalous low velocities ( $\mathrm{Vp}=6.48-$ $6.65 \mathrm{~km} / \mathrm{s}$ ). These, associated with the prominent elevations of the Mar and Mantiqueira ranges, a crustal thickness of $32 \mathrm{~km}$, and the Bouguer anomaly, suggests that the mafic portion of the lower crust has been delaminated by a geodynamic process somehow correlated to the opening of the South Atlantic Ocean. The delamination was followed by regional flexural uplift and prominent alkaline magmatism. That event helped to mold the current geometry of the northeastern flank of the Paraná Basin.

The top of the upper mantle has $\mathrm{Vp}=7.88-7.92 \mathrm{~km} / \mathrm{s}$ near the continental margin (SE part of the profile), and $\mathrm{Vp}=8.25 \mathrm{~km} / \mathrm{s}$ under the basin (NW part of the profile). These $\mathrm{Vp}$ reveals that the two lithospheric mantle domains have distinguished origins and evolutions. 


\section{CAPÍTULO 1 - INTRODUÇÃO}

O estudo da atual estrutura interna da litosfera, bem como da composição e estado físico do limite crosta-manto, proporciona a progressão do entendimento sobre os mecanismos e processos geodinâmicos que atuam - ou atuaram - na base da crosta e no manto superior em determinada região.

Assim, para melhor compreender a evolução da Bacia do Paraná e de seu embasamento e unidades adjacentes, como faixas móveis neoproterozóicas, terrenos tectonoestratigráficos, blocos litosféricos e crátons, bem como a influência dessas entidades geotectônicas na formação e evolução da margem continental sudeste brasileira durante e após a abertura do Atlântico Sul no Cretáceo, é preciso conhecer a presente estrutura da litosfera.

Para tal finalidade, o método de refração/reflexão sísmica de ângulo amplo assume função de poderosa ferramenta investigativa, pois permite o controle da distribuição do campo de velocidades das ondas sísmicas no meio e o posicionamento das principais descontinuidades em profundidade.

Nos últimos anos, no Brasil, vêm sendo envidados esforços no sentido de utilizar métodos sísmicos (Bassini, 1986 e referências ali contidas; Soares, 2005; Soares et al., 2006; Tavares, 2014; Evain et al., 2015; Lima et al., 2015) e sismológicos (Assumpção et al., 2002; França \& Assumpção, 2004; Julià et al., 2008; Rocha et al., 2011; Trindade, 2014; Azevedo et $a l ., 2015)$ para mapear a estrutura profunda da crosta e manto superior e, com isso, aprimorar o entendimento da compartimentação tectônica e evolução crustal do território brasileiro.

A presente dissertação descreve os trabalhos de levantamento, processamento, modelagem e interpretação dos dados do experimento de refração/reflexão sísmica de ângulo amplo do perfil PABBRISE (PAraná Basin, Brasília-RIbeira belts Seismic Experiment), realizado no Estado de São Paulo no segundo semestre de 2013. O perfil PABBRISE é continuação em terra de perfil de refração sísmica profunda realizado em mar pelo IFREMER (Institut Français de Recherche pour l'Exploitation de la Mer), com a parceria do LabLitos/UnB, no escopo do projeto SanBa (Santos Basin - Evain et al., 2015).

Os dados foram obtidos no âmbito do projeto de pesquisa intitulado "Estudo da Transição da Crosta Continental-Crosta Oceânica na Região Sudeste do Brasil: Experimentos de Refração Sísmica Profunda e Magnetotelúrico e Estudos Geológicos na Faixa Ribeira e Bacia do Paraná - Transecta Refração (PETROBRAS/UnB - 2012/05132)”. 
O principal objetivo desta dissertação é, a partir de modelagem direta 2-D dos tempos de trânsito das ondas P (pacote de programas RAYINVR, Zelt \& Smith, 1992) pelo método de traçado de raios (Červený et al., 1977; Červený, 2001, e referências ali contidas), determinar a estrutura e o campo de velocidade da crosta e do topo do manto superior sob a porção nordeste da Bacia do Paraná e das faixas Brasília meridional e Ribeira no Estado de São Paulo. A partir desse conhecimento, discutir da implantação e evolução da bacia e da margem continental sudeste brasileira por meio da integração do modelo obtido com demais informações geológicas e geofísicas existentes.

Este documento é parte dos requisitos necessários para a obtenção do grau de Mestre em Geologia pelo Programa de Pós-Graduação em Geologia do Instituto de Geociências da Universidade de Brasília (IG/UnB). O trabalho foi orientado pelos professores Dr. Reinhardt A. Fuck e Dr. José Eduardo P. Soares.

A área de estudo abrangida pelo experimento de refração sísmica profunda está localizada no Estado de São Paulo. O experimento sísmico teve início no município de Santa Clara D’Oeste, próximo às barrancas do Rio Paraná, e final em Caraguatatuba, litoral norte paulista, resultando em perfil de direção NW-SE com aproximadamente $700 \mathrm{~km}$ de extensão (Figura 1.1) 


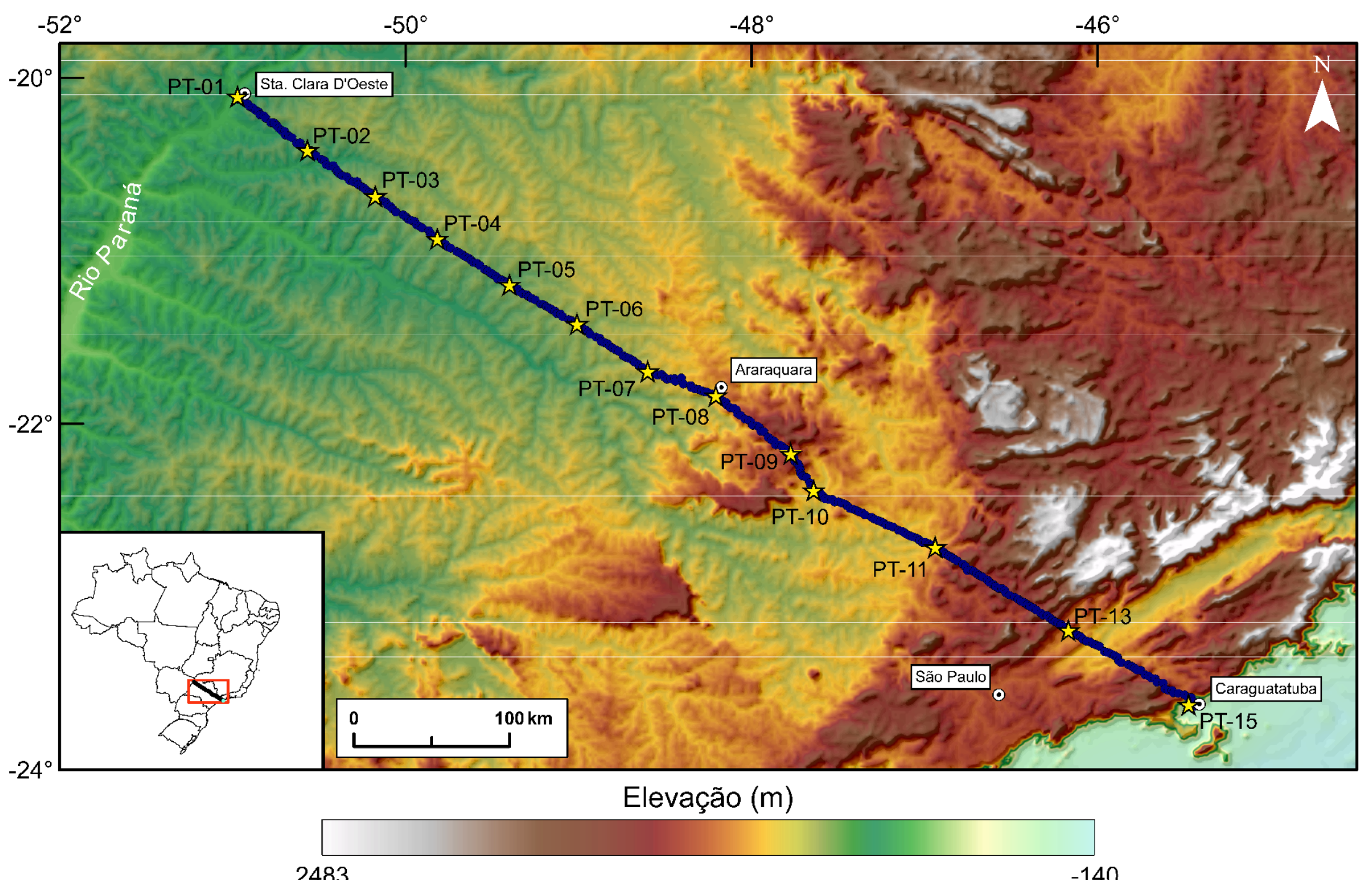

Figura 1.1 Mapa de relevo com a localização do perfil sísmico PABBRISE. As estrelas representam os pontos de tiro (PT) e os círculos azuis representam as estações de registro do experimento. O mapa inserido (canto inferior esquerdo) revela a localização do experimento no contexto do território brasileiro. Algumas cidades do Estado de São Paulo e o Rio Paraná foram destacados ao longo do perfil para auxiliar na localização. O modelo de relevo utilizado foi o ETOPO1 (Amante \& Eakins, 2009). 


\section{CAPÍTULO 2 - CONTEXTO TECTÔNICO DA REGIÃO EM ESTUDO}

O perfil PABBRISE atravessa, em superfície e de noroeste para sudeste, parte das seguintes unidades geotectônicas da porção sudeste do Brasil: Bacia do Paraná, Faixa Brasília meridional (Nappe Socorro-Guaxupé), Faixa Ribeira (terrenos Apiaí-São Roque e EmbuParaíba do Sul), o segmento meridional do Graben de Taubaté e, novamente a Faixa Ribeira (terreno Oriental/Arco Magmático Rio Negro) (Figura 2.1).

A escala de tempo absoluta aqui empregada é a International Stratigraphic Chart da International Comission on Stratigraphy (Cohen et al., 2013).

\subsection{Faixa Brasília meridional: Nappe Socorro-Guaxupé}

Junto das faixas móveis Paraguai e Araguaia, a Faixa Brasília compõe o conjunto dos cinturões orogênicos pertencentes à Província Tocantins (Almeida et al., 1981) que, por sua vez, representa um sistema orogênico neoproterozóico ramificado desenvolvido entre os paleocontinentes Amazônico, São Francisco-Congo e os blocos litosféricos sob as bacias fanerozóicas do Paraná e do Parnaíba.

A Faixa Brasília possui proeminente concavidade para leste, em direção ao Cráton do São Francisco, e é subdividida em dois segmentos de diferentes orientações e estilos estruturais: a Faixa Brasília setentrional, de direção geral NE-SW, onde predominam exposições de embasamento paleoproterozóico parcialmente coberto por sequências paleo-, meso- e neoproterozóicas levemente dobradas; e a Faixa Brasília meridional, com direção geral NW$\mathrm{SE}$, onde predominam sistemas de nappes e de dobras e empurrões com vergência geral para o Cráton do São Francisco (Fuck et al., 1994, 2005; Dardenne, 2000; Pimentel et al., 2000; Valeriano et al., 2008).

Tanto o segmento setentrional, quanto o meridional da Faixa Brasília são compartimentados em zona externa, a leste, e zona interna, a oeste (Fuck et al., 1994 e 2005; Valeriano et al., 2008). 


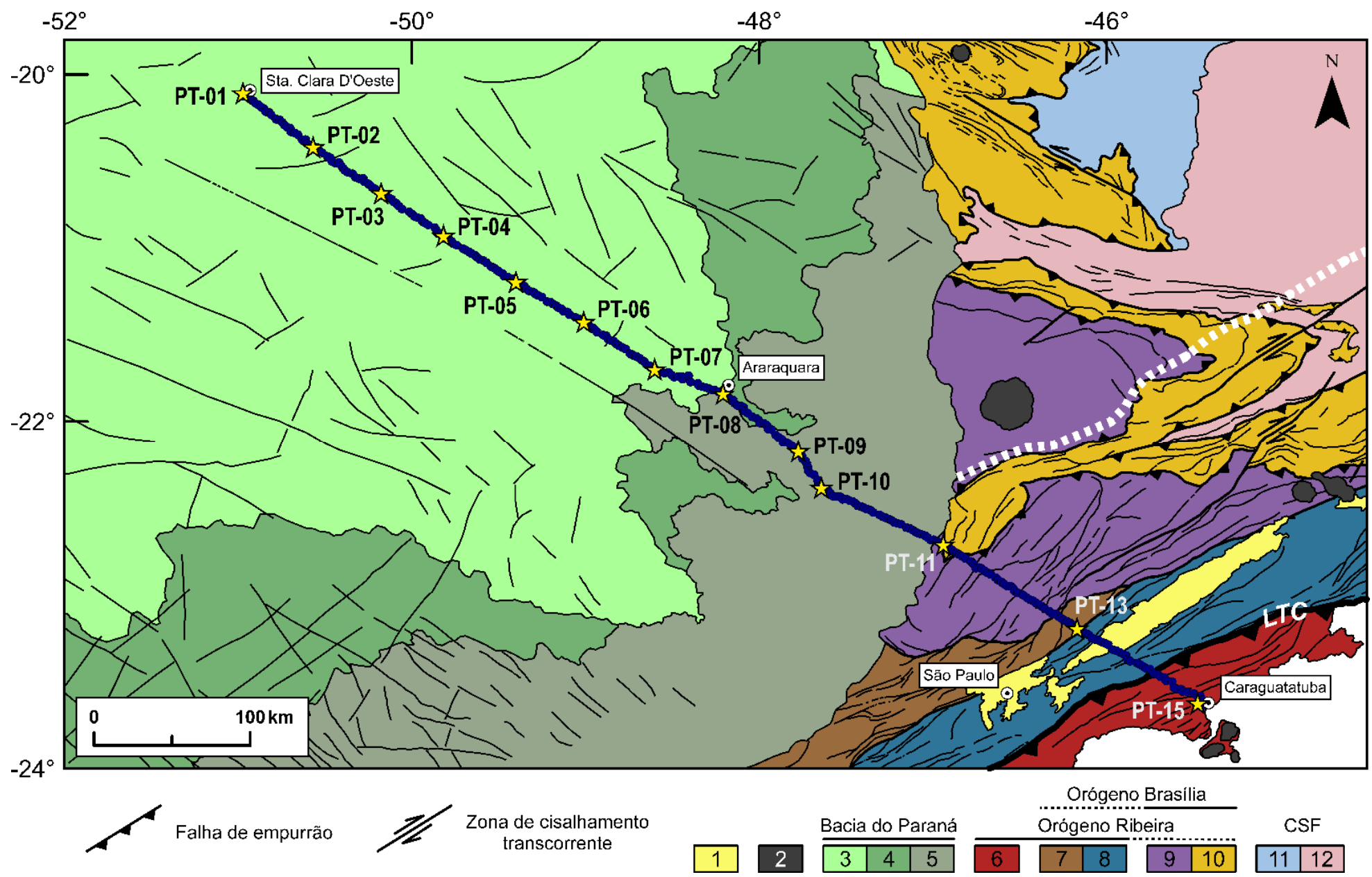

Figura 2.1 Mapa tectônico simplificado da região em estudo (modificado de Heilbron et al., 2004; Perrotta et al., 2005; Peternel et al., 2005 e Trouw et al., 2013 ). Na legenda: 1 Bacias cenozóicas do tipo rifte; 2 - Plútons alcalinos do Cretáceo Superior/Cenozóico; Bacia do Paraná: 3 - Grupo Bauru (Cretáceo Superior); 4 - Formação Serra Geral (Cretáceo Inferior); 5 - Rochas pré-vulcânicas (Mesozóico/Paleozóico); 6 - Terreno Oriental (Arco Rio Negro); 7 - Terreno Apiaí-São Roque; 8 - Terreno Embu-Paraíba do Sul; 9 - Nappe Socorro-Guaxupé; 10 - Sistema de nappes Andrelândia, Nappe Passos e Klippe Carrancas; Cráton do São Francisco e seu antepaís: 11 - Cobertura (Grupo Bambuí); 12 - Cráton do São Francisco. LTC - Limite Tectônico Central (sutura). A linha tracejada em branco representa a influência da frente de deformação da Faixa Ribeira (segundo Trouw et al., 2013). Estrelas representam os pontos de tiro, PT, (01-11,13 e 15) e círculos azuis representam as estações receptoras do perfil PABBRISE. Círculos brancos destacam a localização de algumas cidades do Estado de São Paulo. 
A zona externa da Faixa Brasília meridional representa domínio com imbricações de escamas de empurrão de sucessões siliciclásticas, e algumas carbonáticas, dadas pelos grupos Paranoá, Canastra, Ibiá, Vazante e a porção basal do Grupo/Megassequência Andrelândia. A fácies metamórfica predominante nesses grupos é xisto-verde, comumente até a zona da granada. Essas rochas metassedimentares alóctones são interpretadas como de margem passiva neoproterozóica, embora alguns estudos (Pimentel et al., 2001; Piuzana et al. 2003) sugerem que pelo menos parte delas correspondam a depósitos de retroarco neoproterozóico. Segundo Valeriano et al. (2008), a história deformacional da zona externa meridional iniciou-se com o desenvolvimento sin-metamórfico de uma foliação com mergulho suave associada a cisalhamento sub-horizontal, seguida de dobramentos acompanhados por imbricações de escamas de empurrão com vergência geral para leste-sudeste, rumo ao Cráton do São Francisco ou tangente à sua borda meridional.

A zona interna da Faixa Brasília meridional constitui sistemas de nappes carreadas sobre o conjunto de dobras e empurrões da zona externa e segmentadas por rampas laterais materializadas como zonas de falha subverticais. Estas, por sua vez, atuaram como zonas de transferência, auxiliando no transporte tectônico das nappes que, de maneira geral, ocorreu por mais de $200 \mathrm{~km}$ e de oeste para leste (Campos Neto \& Caby, 2000; Valeriano et al., 2008). As nappes da zona interna mostram gradiente metamórfico invertido. As paragêneses minerais das rochas das porções inferiores indicam fácies xisto-verde, enquanto que as do topo alcançaram fácies anfibolito e mesmo fácies granulito. Fazem parte desse contexto o Grupo Araxá e rochas associadas (mélanges ofiolíticas e leucogranitos sin-colisionais), parte do Grupo/Megassequência Andrelândia, o complexo granulítico Anápolis-Itauçu e a Nappe Socorro-Guaxupé, no extremo sudeste da faixa móvel (Valeriano et al., 2008). Esta última tem sua porção meridional atravessada pelo perfil sísmico PABBRISE (ver mapa da fígura 2.1).

A Nappe Socorro-Guaxupé é composta por dois segmentos: Guaxupé, ao norte, e Socorro, ao sul. Suas rochas constituintes são principalmente granulitos máficos, próximo à base, e suíte intrusiva sin-tectônica de rochas com afinidade charnockítico-mangerítica e assinatura calci-alcalina. Essas rochas possuem idade de cristalização no intervalo de 670-625 Ma e atingiram temperaturas de $900-950^{\circ} \mathrm{C}$, referentes à fácies metamórfica granulito, no principal estágio colisional do orógeno, por volta de 630-625 Ma (Campos Neto, 2000; Campos Neto \& Caby, 2000; Heilbron et al., 2004). Este último período está inserido no intervalo de 650-610 Ma, identificado como o pico do metamorfismo da Faixa Brasília meridional relacionado à colisão continental entre o paleocontinente São Francisco-Congo e o arcabouço 
litosférico sob a Bacia do Paraná (Heilbron et al., 2004; Trouw et al., 2013 e referências ali contidas). Sienitos e granitos, pós-tectônicos e de alto-K, intrudiram a nappe no intervalo 612 590 Ma (Pimentel et al., 1996; Töpfner, 1996, apud Campos Neto \& Caby, 2000).

A Nappe Socorro-Guaxupé é interpretada por Campos Neto \& Figueiredo (1995) como a raiz deformada e exumada de um arco magmático neoproterozóico formado ao longo da paleomargem continental ativa, possivelmente associada ao arcabouço litosférico sob a Bacia do Paraná. Essa interpretação é reforçada pelos valores negativos de $\varepsilon_{N d}(t)$, de -20 a -13 , encontrados para as rochas da nappe (Trouw et al., 2013 e referências ali contidas). Trouw et al. (2013) correlacionam a nappe ao Arco Magmático de Goiás e ao complexo granulítico Anápolis-Itauçu, também no Estado de Goiás.

\subsection{Faixa Ribeira}

A Faixa Ribeira é um dos orógenos que compõem a Província Mantiqueira (Almeida et al., 1981), um sistema orogênico neoproterozóico-eocambriano diacrônico, que se estende pela costa atlântica, do sul da Bahia ao Uruguai. Este sistema também engloba os orógenos Araçuaí, Dom Feliciano e São Gabriel, e a zona de interferência entre as faixas Brasília meridional e Ribeira (Heilbron et al., 2004). A Faixa Ribeira possui tendência estrutural geral NE-SW, resultado da interação e colisão oblíqua, há cerca de 580 Ma, entre o Cráton do São FranciscoCongo, outra(s) microplaca(s) e o Arco Magmático Rio Negro, situados a sudeste do cráton. Esta colisão oblíqua resultou em partição da deformação com o predomínio de regiões de encurtamento frontal NW-SE, e zonas com componente transpressivo destral, resultando em foliação de direção geral NE-SW com mergulho íngreme predominante para sudeste (Heilbron et al., 2004; Trouw et al., 2013).

Há diversas propostas para a compartimentação geotectônica da Faixa Ribeira. Neste trabalho optou-se por utilizar a proposta de Heilbron et al. (2004). Nesta concepção os autores subdividem a faixa neoproterozóica em cinco terrenos tectonoestratigráficos que, como no sentido definido por Howell (1989), são separados ora por falhas de empurrão, ora por zonas de cisalhamento oblíquas transpressivas. Os terrenos são denominados Ocidental, Embu, Paraíba do Sul, Oriental (Arco Magmático Rio Negro) e Cabo Frio. Entretanto, da zona de interferência para sul, até a borda norte do maciço cratônico Luís Alves, estendem-se ainda o terreno Apiaí-São Roque e parte do terreno Embu, cujas correlações geotectônicas com a Faixa 
Ribeira são ambíguas e que, pelo menos em parte, poderiam pertencer à Faixa Brasília meridional (Heilbron et al. 2004; Trouw et al., 2013).

O terreno Ocidental é composto por porções de embasamento retrabalhado derivado do Cráton do São Francisco, intercalado com rochas metassedimentares neoproterozóicas do Grupo/Megassequência Andrelândia, interpretado por Paciullo et al. (2000) como representativo do ambiente de uma paleomargem passiva.

O terreno Embu tem sido descrito como um corpo lenticular delimitado por duas importantes zonas de cisalhamento, a Zona de Cisalhamento Caucaia-Rio Jaguarí-Buquira, a noroeste, e a Zona de Cisalhamento Cubatão, a sudeste. Esse terreno contém lentes alongadas de embasamento paleoproterozóico e cobertura metassedimentar. A fácies metamórfica presente no terreno Embu é predominantemente anfibolito. Por meio de datação em monazita, Vlach (2001, apud Trouw et al., 2013) estimou a idade do evento metamórfico que afetou esse terreno em torno de 790 Ma.

O terreno Paraíba do Sul também é composto por duas unidades principais: embasamento paleoproterozóico, onde ocorrem gnaisses com enclaves de rochas máficas, ultramáficas e calcissilicáticas, e um complexo metassedimentar. A transição entre os terrenos Embu e Paraíba do Sul é tradicionalmente dada por uma zona de cisalhamento. No entanto, Eirado et al. (2006) descrevem que as rochas presentes em ambos os terrenos são muito similares e que a transição entre eles parece ser gradual. Em decorrência, Heilbron et al. (2008) e Trouw et al. (2013) tratam esses terrenos como uma única entidade, o terreno Embu-Paraíba do Sul.

O terreno Oriental é representado principalmente pelo Arco Magmático Rio Negro, de idade neoproterozóica, envolto por paragnaisses do Domínio Costeiro, possivelmente também do Neoproterozóico (Trouw et al., 2013). As fácies metamórficas registradas neste terreno variam entre anfibolito e granulito. A deformação principal é representada por xistosidade associada a dobras isoclinais a apertadas (Heilbron et al., 2004).

O terreno Cabo Frio, de ocorrência restrita no sudeste do Estado do Rio de Janeiro, é formado por embasamento paleoproterozóico e rochas metassedimentares pelíticas e psamíticas do Ediacarano metamorfizadas em fácies granulito de alta pressão durante a colisão com a Faixa Ribeira, por volta de 530-510 Ma (Schmitt et al., 2004).

A zona de interferência entre a Faixa Brasília meridional e a Faixa Ribeira central é caracterizada pela superposição de estruturas e metamorfismo relacionados às colisões ocorridas em ambas as faixas, de contrastantes direções de transporte tectônico e polaridades 
metamórficas. Diferentes interpretações para a zona de interferência e o limite entre esses dois cinturões orogênicos quase-perpendiculares foram propostas por vários pesquisadores e são revisadas e discutidas por Trouw et al. (2013).

O principal evento colisional da Faixa Ribeira central ocorreu entre 590-550 Ma e envolveu a margem passiva do paleocontinente São Francisco-Congo e o terreno Oriental. Houve subducção de litosfera oceânica da paleoplaca São Francisco-Congo, para sudeste, sob o terreno Oriental, formando o Arco Magmático Rio Negro (Tupinambá et al., 2000; Heilbron \& Machado, 2003; Heilbron et al., 2004 e 2008;). A sutura que separa essas duas entidades tectônicas é denominada de Limite Tectônico Central, LTC (Almeida et al., 1998; Heilbron \& Machado, 2003) (ver mapa da figura 2.1).

Na Faixa Ribeira, de maneira geral, ocorrem ainda diversas suítes de rochas graníticas e granitoides, a maioria do Neoproterozóico, com caráter pré-, sin- ou pós-colisional em relação à atividade ao longo das zonas de cisalhamento regionais (Riccomini et al., 2004). Valeriano et $a l$. (2011) descrevem granitos tipo-I pós-colisionais na porção central da Faixa Ribeira, Estado do Rio de Janeiro, a nordeste da região do presente estudo. As idades U-Pb em zircão e titanita obtidas pelos autores estão compreendidas no intervalo 511,2 $\pm 6,9 \mathrm{Ma}$ e 480,7 $\pm 6,1 \mathrm{Ma}$. Esse magmatismo Cambro-Ordoviciano marca a zona onde aquecimento e fusão parcial da crosta continental inferior ocorreu, segundo os autores, ou por quebra da placa subductada, ou por colapso da crosta continental aquecida e espessada.

\subsection{Bacia do Paraná}

A Bacia do Paraná representa área de aproximadamente 1,5 milhão km² de sedimentação e magmatismo fanerozóicos - Meso-Ordoviciano ao final do Cretáceo Superior - presentes na porção sudeste do continente sul-americano. Comumente classificada como do tipo cratônica, ela possui formato ovalado, com eixo maior de aproximadamente $1.750 \mathrm{~km}$ na direção NNESSW, largura média de aproximadamente $900 \mathrm{~km}$, espessura total máxima da pilha sedimentarmagmática por volta de $7.000 \mathrm{~m}$ e seu depocentro estrutural coincide espacialmente com a região de calha do Rio Paraná (Zalán et al., 1990, 1991; Milani et al., 2007).

$\mathrm{O}$ atual contorno da bacia é determinado por limites erosivos e/ou tectônicos ( $\operatorname{arcos}$ e soerguimentos) associados a eventos tectônicos atuantes no Continente Sul-Americano, grande parte desses durante o Meso-Cenozóico (Zalán et al., 1990; Milani et al., 2007). 
Próximo à região em estudo, o flanco norte-nordeste da bacia é delimitado pelo Arco de Goiânia/Alto Paranaíba. Esse arqueamento periférico de direção NW-SE ocorreu na porção meridional da faixa móvel neoproterozóica Brasília e está associado a inúmeras intrusões alcalinas, kimberlitos e diques máficos. Zalán et al. (1990) interpretam esse arco como a resposta flexural da crosta às cargas sedimentar e vulcânica da Bacia do Paraná.

Na borda nordeste da bacia, onde a transecta foi realizada, a sul do Arco de Goiânia/Alto Paranaíba e a norte da zona de falha Guapiara, as sequências sedimentares afinam para leste ou foram erodidas sem significativa interferência tectônica por falhamentos (Zalán et al., 1990, 1991).

Diversas propostas e sínteses de natureza regional publicadas entre as décadas de 19601990 buscaram retratar o registro estratigráfico da Bacia do Paraná. Entretanto, os estudos cronoestratigráficos das rochas sedimentares da bacia ainda deixam inúmeras questões em aberto devido à ausência de componentes bioestratigráficos vinculados às escalas internacionais de tempo geológico (Milani et al., 2007). No presente trabalho opta-se por adotar a proposta aloestratigráfica regional apresentada por Milani (1997) e revisada por Milani et al. (2007). Tal escolha tem como base dois fatores: é a proposta mais recente, ou seja, incorpora o conhecimento prévio contido nas anteriores e representa versão adequada para estudos tectônicos regionais, uma vez que adota unidades amplas: as superssequências, no sentido definido por Vail et al. (1977).

As superssequências da Bacia do Paraná, cada uma delas envelopada por superfícies de discordância de caráter inter-regional, são: Rio Ivaí (Ordoviciano-Siluriano), Paraná (Devoniano), Gondwana I (Carbonífero-Eotriássico), Gondwana II (Meso a Neotriássico), Gondwana III (Neojurássico-Eocretáceo) e Bauru (Neocretáceo). As três primeiras representam sucessões sedimentares definidas por ciclos transgressivos-regressivos relacionados a variações do nível relativo do mar no Paleozóico; as demais atestam progressiva continentalização dos depósitos sedimentares da bacia (Milani, 1997; Milani \& Ramos, 1998; Milani et al., 2007).

O preenchimento sedimentar da Bacia do Paraná é predominantemente de natureza siliciclástica. A presença de camadas e lentes de calcário e evaporitos é pouco expressiva, exceto por ocorrências muito locais associadas à Formação Irati (Permiano da Superssequência Gondwana I). Essas características do registro sedimentar refletem a localização dessa parte do paleocontinente Gondwana em elevadas latitudes meridionais durante o Paleozóico (Zalán et al., 1990). 
Dois episódios magmáticos interceptam o registro sedimentar da Bacia do Paraná. O mais antigo, Basalto Três Lagoas, foi amostrado próximo à base do poço perfurado junto ao Rio Paraná na porção central da bacia, Estado do Mato Grosso do Sul. Essa rocha está associada à superssequência basal Rio Ivaí e foi datada de $443 \pm 10$ Ma pelo método ${ }^{40} \mathrm{Ar} /{ }^{39} \mathrm{Ar}$ em plagioclásio (Milani, 2004). É importante ressaltar que Mizusaki (1989, apud Milani, 2004), em relatório interno sobre o poço, descreve arenitos líticos derivados do retrabalhamento dessa rocha ígnea, fato que corrobora sua correlação cronoespacial com a superssequência basal da bacia. Para Milani (2004), tal ocorrência marca o evento que deu origem à Bacia do Paraná. O segundo episódio é composto pelo magmatismo Serra Geral (Superssequência Gondwana III). Esse intenso magmatismo fissural, associado a diques e soleiras por toda a bacia, representa os maiores derrames de basaltos continentais fanerozóicos do mundo (Milani et al., 2007). Com um volume de aproximadamente $2,35 \times 10^{6} \mathrm{~km}^{3}$ (Gladczenko et al., 1997), seu depocentro no extremo oeste do Estado de São Paulo alcança quase 2.000 m de espessura (Milani, 2004; Milani et al., 2007).

Petrologicamente, a Formação Serra Geral é dominada por basaltos toleíticos e andesitos basálticos, com alguns riolitos e riodacitos subordinados (Peate et al., 1992). Em uma abordagem geoquímica, há proeminente diferenciação em teores de $\mathrm{TiO}_{2}$, de modo que, na porção setentrional da bacia predominam rochas ricas em $\mathrm{TiO}_{2}(>2 \%)$, enquanto que na porção meridional dominam os termos empobrecidos nesse componente ( $\leq 2 \%)$ (Bellieni et al., 1984). Em trabalhos recentes, Rocha-Júnior et al. (2012, 2013), por meio de novos dados geoquímicos e isotópicos (sistemáticas $\mathrm{Re}-\mathrm{Os}$ e $\mathrm{Sr}-\mathrm{Nd}-\mathrm{Pb}$, elementos siderófilos e elementos traços incompatíveis) propõem que os basaltos de derrame continental da Formação Serra Geral foram derivados de magmas provenientes de fonte sublitosférica metassomatizada. Os autores defendem que a fonte mantélica teria sido enriquecida por fluidos e/ou magmas relacionados aos processos de subducção ocorridos durante o Neoproterozóico e que a pluma de Tristão da Cunha não teria participado da gênese desses basaltos continentais, em contraste com o que é defendido por Ernesto et al. (2002).

Datações realizadas por meio do método ${ }^{40} \mathrm{Ar} /{ }^{39} \mathrm{Ar}$ sugerem que o magmatismo Serra Geral teve duração < 1,2 milhão de anos e foi iniciado há 134,7 \pm 1 Ma, o que resultou em uma taxa de erupção mínima geral de $\sim 2,0 \mathrm{~km}^{3}$ de magma por ano (Renne et al., 1996 e referências ali contidas; Thiede \& Vasconcelos, 2010). Por meio de isócrona pelo método ${ }^{187} \mathrm{Re} /{ }^{187} \mathrm{Os}$, Rocha-Júnior et al. (2012) obtiveram idade de 131,6 \pm 2,3 Ma para os basaltos, intervalo relativamente concordante com os resultados obtidos pelo método ${ }^{40} \mathrm{Ar} /{ }^{39} \mathrm{Ar}$ supracitado. Por 
outro lado, os trabalhos de Turner et al. (1994) e Stewart et al. (1996) indicam um período extrusivo de $\sim 11$ milhões de anos, que teria começado em torno de 140 Ma e terminado por volta de $129 \mathrm{Ma}$. Tal intervalo teria proporcionado uma taxa de erupção mínima geral muito menor, quando comparada às taxas de outras províncias de derrames basálticos continentais pelo mundo. Thiede \& Vasconcelos (2010) sugerem que a ampla distribuição de idades obtida por Turner et al. (1994) e Stewart et al. (1996) representa, na verdade, artefato do método ${ }^{40} \mathrm{Ar} /{ }^{39} \mathrm{Ar}$ utilizado por esses autores e, portanto, não denotaria o verdadeiro intervalo de idades para as extrusões.

Há pelo menos cinco principais interpretações para a origem e evolução da Bacia do Paraná. Fúlfaro et al. (1982) defendem que diversas calhas de direção NW-SE e com características aulacogênicas teriam condicionado o início da sedimentação. Em contrapartida, Zalán et al. (1990) conferem ao mecanismo de contração térmica posterior ao Ciclo Brasiliano importância efetiva para a implantação da bacia. Para Soares (1991, apud Milani et al., 2007) o mecanismo de flexura litosférica gerou o abatimento de blocos do embasamento que, por sua vez, controlou a deposição inicial. O autor ainda afirma que não há indícios de um grande rifte precursor gerado por evento de estiramento litosférico. Por outro lado, Marques et al. (1993, apud Milani, 2004), em relatório interno, atestam a existência de um rifte central alinhado ao eixo NE-SW do Rio Paraná, e que seria responsável por acomodar o pacote sedimentar da Superssequência Rio Ivaí. Por último, Milani (1997) e Milani \& Ramos (1998) atribuem a subsidência inicial à reativação transtrativa de zonas de fraqueza NE-SW resultantes do Ciclo Brasiliano e a evolução dessa subsidência à flexura litosférica regional por sobrecarga tectônica, ambas devido a uma série de episódios orogênicos ocorridos na borda sul-ocidental do paleocontinente Gondwana - os Gondwanides - uma extensa faixa de orógenos fanerozóicos e bacias associadas.

Ao realizar análise da evolução termomecânica da Bacia do Paraná, Oliveira (1987, apud Zalán et al., 1990) identificou três principais estágios de subsidência para a mesma: Siluro-Devoniano, Permo-Carbonífero e Juro-Cretáceo (Figura 2.2). Posteriormente, Quintas et al. (1999) também realizaram estudo termomecânico da bacia, com base no registro de 81 poços exploratórios. Os autores aplicaram modelos de estiramento por cisalhamento puro e, por meio da técnica de backstripping, identificaram dois eventos de estiramento litosférico (atenuação E): o primeiro há 440 Ma e o segundo há 296 Ma. Para eles, esses dois eventos de estiramento contribuíram para a formação e evolução da Bacia do Paraná. 


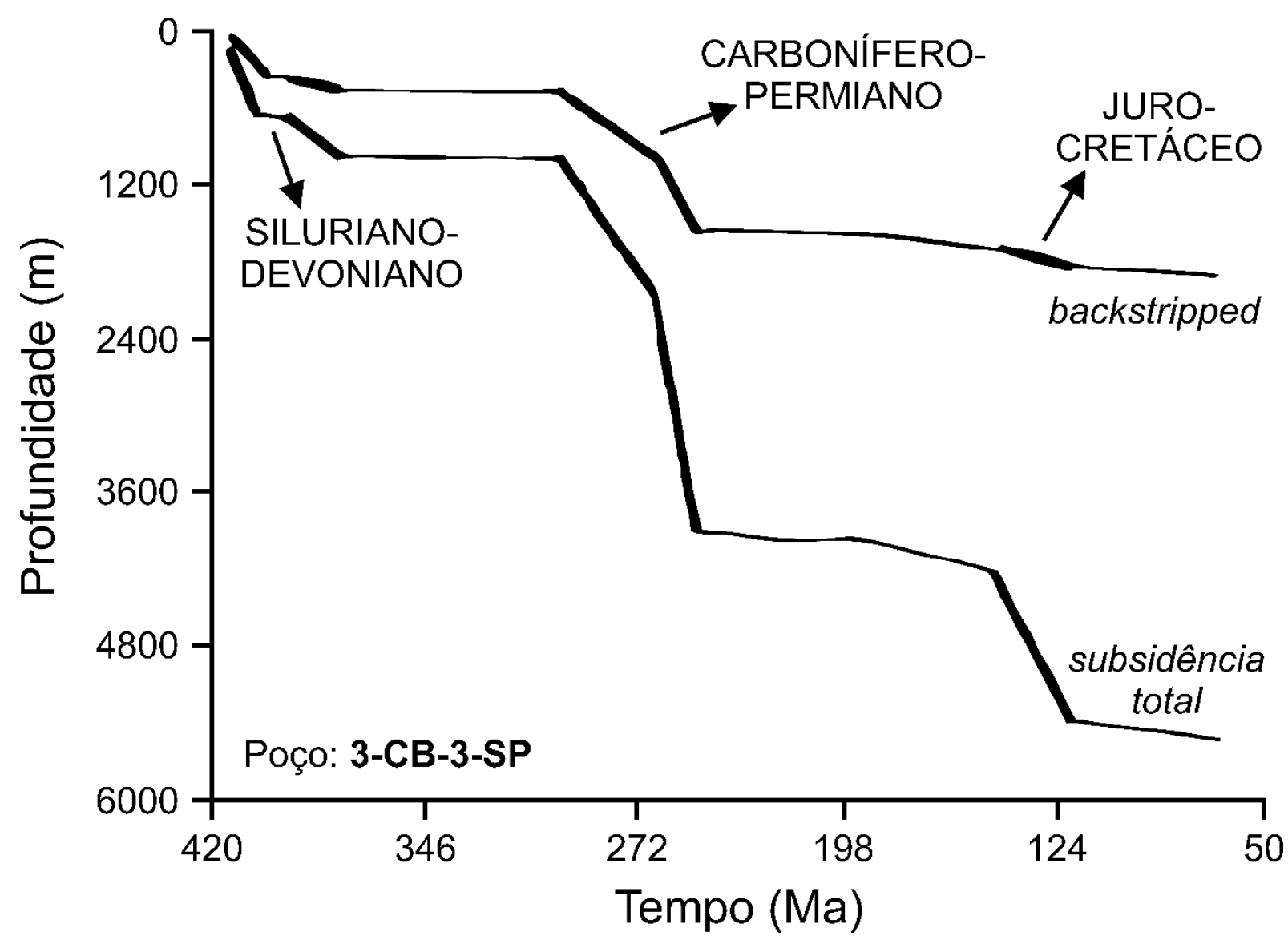

Figura 2.2 Curvas de subsidências total e backstripped para o poço 3-CB-3-SP e que retratam os três principais estágios de subsidência identificados por Oliveira (1987) (adaptado de Zalán et al., 1990).

A natureza e papel do embasamento da Bacia do Paraná são duas das principais questões ainda em aberto e que norteiam parte dos trabalhos que atualmente são desenvolvidos na região. Parcela desse substrato está exposta, principalmente nas bordas da bacia ou em janelas do embasamento, e pode ser investigada diretamente. Entretanto, a maior parte dele só pode ser estudada por meio de métodos indiretos, principalmente geofísicos.

Leonardos \& Fyfe (1974, apud Mantovani \& Brito Neves, 2009) foram os primeiros a sugerir a existência de possível núcleo cratônico sob a Bacia do Paraná. Campos Neto \& Basei (1983, apud Mantovani \& Brito Neves, 2009), mapearam o domínio litoestrutural Apiaí-São Roque, a leste da bacia, e concluíram que deve haver um núcleo estável sob a bacia, nomeado por eles de Cráton Paraná, e que serviu de antepaís para tal domínio.

Posteriormente, Cordani et al. (1984) e Brito Neves et al. (1984) ao utilizarem, entre outros dados, testemunhos do embasamento obtidos a partir de poços profundos na bacia, refinaram a hipótese de núcleo cratônico e propuseram, pela primeira vez, esboço geotectônico para o embasamento da Bacia do Paraná (Figura 2.3a). Alternativamente, Milani (1997) e 
Milani \& Ramos (1998) ao também utilizarem dados obtidos de poços profundos, propuseram outra interpretação para o arcabouço tectônico do embasamento da Bacia do Paraná. A proposta consiste em embasamento formado por "mosaico" de blocos crustais separados lateralmente por uma faixa móvel neoproterozóica interpretada, denominada de Faixa Rio Paraná (Figura 2.3b). Segundo eles, a existência de um único "núcleo cratônico" na porção central da bacia é uma hipótese que não se ajusta a história de subsidência da mesma. Entretanto, alguns conceitos e preposições defendidos por eles estão em desacordo com estudos geológicos e geofísicos mais recentes (Mantovani \& Brito Neves, 2009).

Diferentemente, Quintas (1995) e Mantovani et al. (2005), ao utilizarem dados de estações gravimétricas instaladas na Bacia do Paraná e suas adjacências, obtiveram mapa de anomalia gravimétrica Bouguer residual (sem a influência das rochas sedimentares e vulcânicas) para o embasamento da bacia. Os resultados obtidos evidenciam anomalia gravimétrica positiva relativamente alinhada à porção central da bacia e delimitada por expressivos gradientes laterais. Os autores interpretam essa anomalia gravimétrica positiva como o antigo núcleo/bloco litosférico, denominando-o de Bloco Paranapanema (Figura 2.3c). 


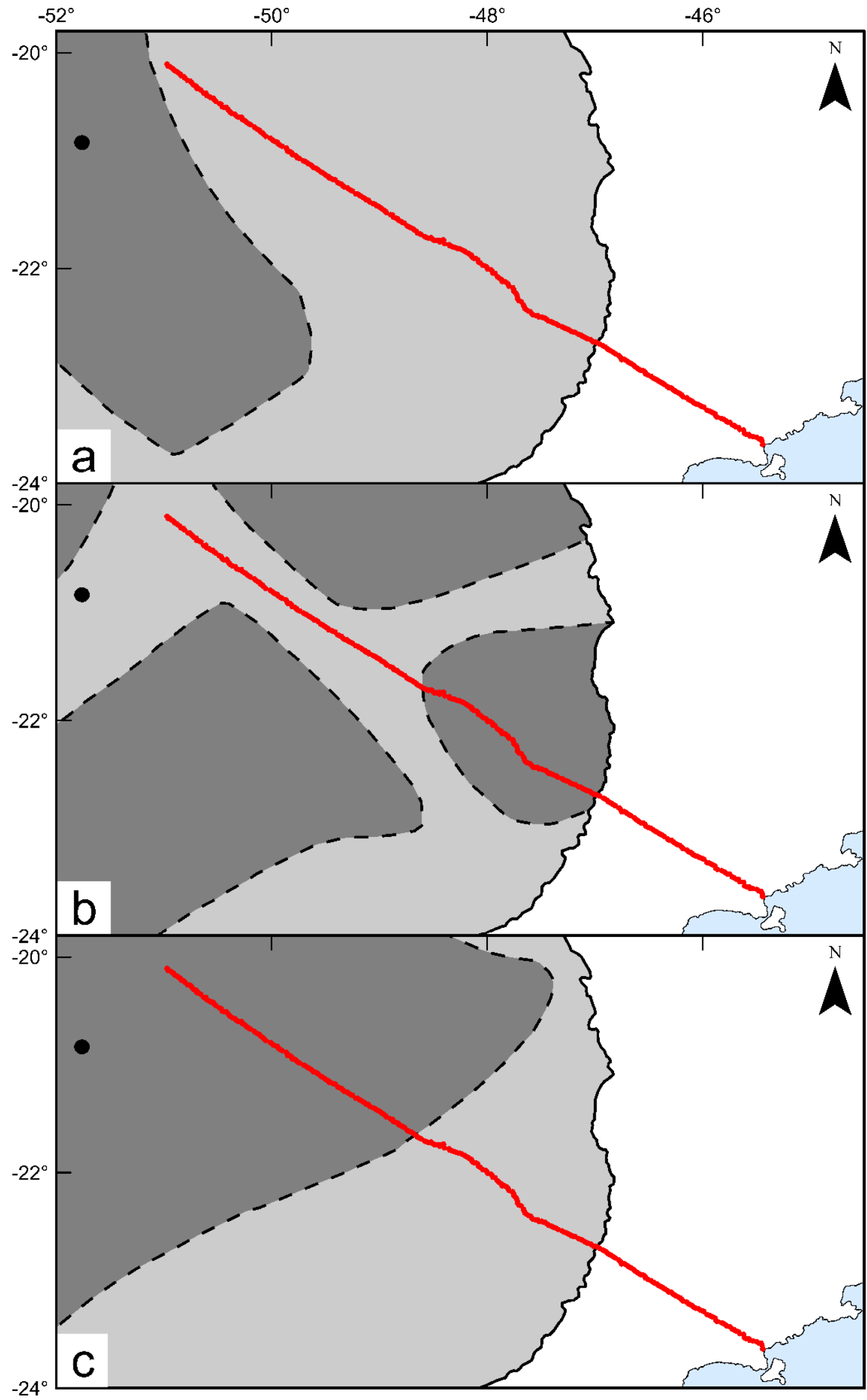

Figura 2.3 Propostas de arcabouço tectônico para o embasamento da Bacia do Paraná na região em estudo. Adaptado de: a) Cordani et al. (1984), b) Milani \& Ramos (1998) e, c) Mantovani et al. (2005). A área da bacia aparece em cinza claro, enquanto que os "blocos cratônicos" propostos sob ela estão em cinza escuro. O ponto preto define a localização do poço profundo onde foi encontrado o basalto Três Lagoas. O perfil sísmico PABBRISE encontra-se em vermelho. 


\subsection{Sistema de Riftes Cenozóicos do Sudeste do Brasil}

\subsubsection{Origem e evolução estrutural}

O arranjo de planaltos, escarpas e mares de morros, de direção geral NE-SW, representado pelas serras do Mar e da Mantiqueira, compõem a mais acentuada feição topográfica da borda atlântica leste-sudeste do Continente Sul-Americano (Almeida \& Carneiro, 1998).

A Serra do Mar é formada por conjunto de planaltos e escarpas, com cerca de $1.500 \mathrm{~km}$ de extensão e elevações médias entre 800 e 1.200 m de altitude, que vão desde o norte de Santa Catarina até o Rio de Janeiro, acompanhando, em geral, a linha de costa sul-sudeste do Brasil. A noroeste dessa feição, mas restrita à divisa entre os estados de São Paulo, Minas Gerais, Rio de Janeiro e Espírito Santo, ocorre a Serra da Mantiqueira. Este conjunto de escarpas e mares de morros, por sua vez, se estende ao longo de aproximadamente $900 \mathrm{~km}$ e atinge altitudes médias entre 1.200 e $1.400 \mathrm{~m}$, com cotas frequentemente acima dos $2.000 \mathrm{~m}$ (Almeida \& Carneiro, 1998; Zalán \& Oliveira, 2005; Gontijo-Pascutti et al., 2012; Zalán, 2012).

A associação das serras do Mar e da Mantiqueira com os vales tectônicos (grabens) intervenientes e suas extensões na plataforma continental sudeste é denominada de Sistema de Riftes Cenozóicos do Sudeste do Brasil (Zalán \& Oliveira, 2005) (Figura 2.4).

Por volta da transição Jurássico-Cretáceo a região em estudo esteve sujeita a fenômenos tectono-termais que resultaram na ruptura continental do Gondwana sul-ocidental e consequente abertura do Oceano Atlântico Sul com formação de crosta oceânica pósbarremiana (Moulin et al., 2010). Essa sucessão de acontecimentos, que posteriormente culminou na progressiva consolidação da Plataforma Sul-Americana (Almeida et al., 2000) como entidade única e individualizada, também foi responsável por desencadear uma série de processos que modificaram profundamente o arcabouço geotectônico e, consequentemente, também o geomorfológico da margem continental sudeste brasileira. 


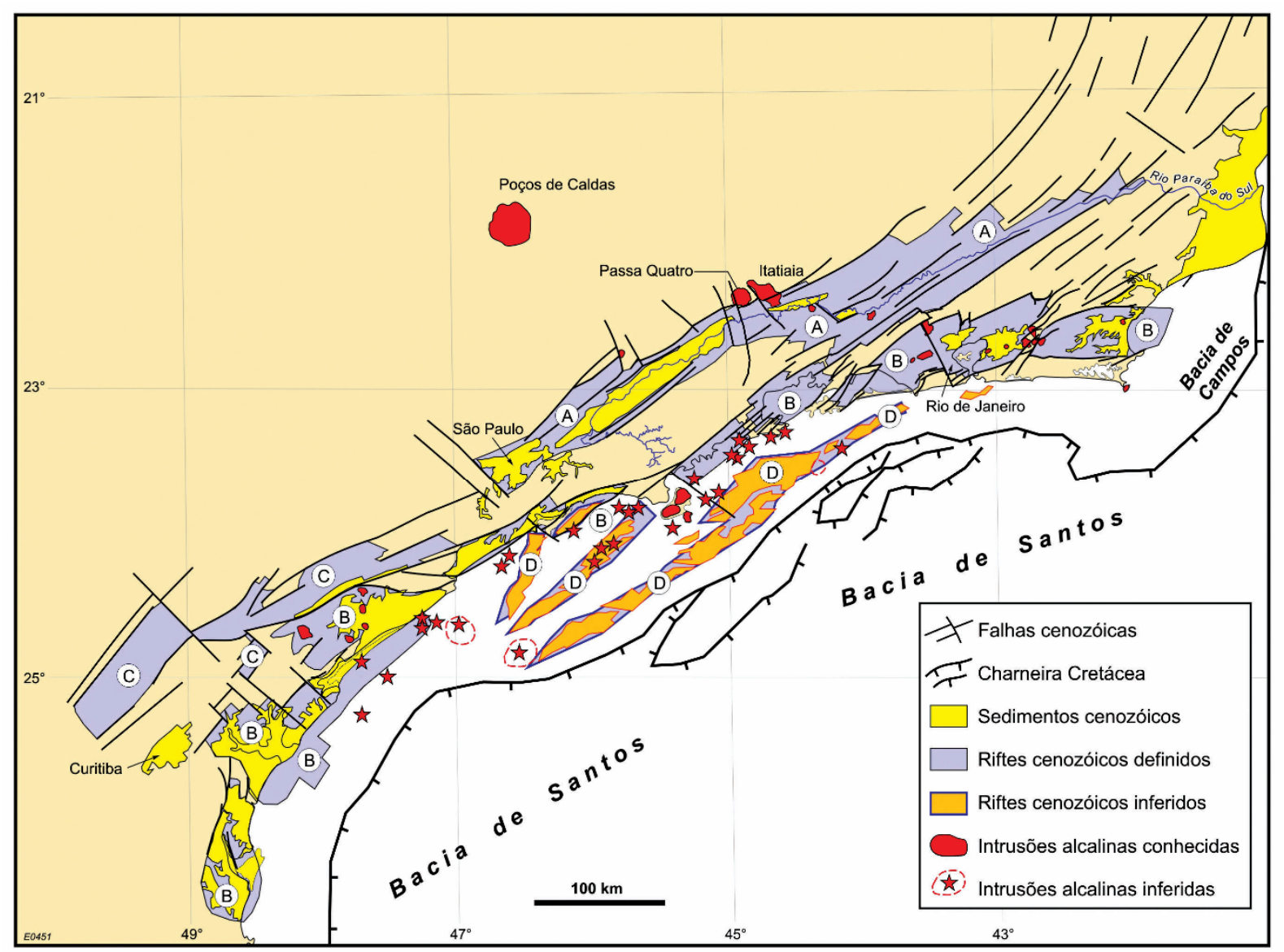

Figura 2.4 O Sistema de Riftes Cenozóicos do Sudeste do Brasil como interpretado por Zalán \& Oliveira (2005).

Esses processos englobam reativações de estruturas do embasamento, soerguimentos e abatimentos, o desenvolvimento de superfícies erosivas regionais e diversas intrusões/diques alcalinos e basálticos. Boa parte desses persistiu, em pulsos descontínuos, desde o Cretáceo até o Neógeno. A correlação desses processos com a origem e evolução do Sistema de Riftes Cenozóicos do Sudeste do Brasil atualmente é aceita com certo consenso entre os pesquisadores do tema (Almeida \& Carneiro, 1998; Riccomini, 1989; Riccomini et al. 2004; Zalán \& Oliveira, 2005; Cogné et al., 2011, 2013; Zalán, 2012; Franco-Magalhães et al., 2014), entretanto o mesmo não ocorre com relação aos mecanismos formadores e modificadores destas feições geomorfo-estruturais.

Segundo o modelo genético-evolutivo de Zalán \& Oliveira (2005), cerca de 25 milhões de anos após o evento de rifteamento ( 134-114 Ma), soerguimento de natureza epirogênica da crosta continental teve início em resposta à deriva da Placa Sul-Americana sobre uma anomalia térmica. Os autores ressaltam que tal anomalia térmica "não seria intensa o suficiente para ser chamada de pluma mantélica" e seria "espalhada demais para ser caracterizada como 
um simples ponto quente (hotspot)". No entanto, buscam correlacioná-la, de certo modo, ao ponto quente de Trindade.

Ocorrido no intervalo Coniaciano-Maastrichtiano ( 90-66 Ma, Cohen et al., 2013), tal soerguimento foi marcado por ausência de tectonismo expressivo. A crosta continental tendo sido soerguida de modo maciço e sem quebramentos expressivos, em espécie de pulso com amplitude entre 2.000 e $3.000 \mathrm{~m}$ e comprimento de onda de poucos milhares de quilômetros (Zalán \& Oliveira, 2005). Houve também intenso magmatismo alcalino, geralmente sobre crosta não estirada, e basáltico, sobre crosta estirada associada às bacias marginais de Santos e Campos. Os planaltos resultantes desse soerguimento, segundo os autores uma "Serra do Mar Cretácea", estendiam-se por mais de $300.000 \mathrm{~km}^{2}$ e foram a principal área-fonte dos sedimentos que preencheram as bacias do Paraná (Grupo Bauru), Santos e Campos nessa época.

Concomitante ao final da ascensão, no limite Cretáceo-Paleógeno (66 Ma, Cohen et al., 2013), uma ampla superfície erosiva havia se desenvolvido e nivelado o topo dos planaltos por volta de $2.000 \mathrm{~m}$ em relação ao atual nível do mar (Almeida \& Carneiro, 1998; Riccomini et al., 2004; Zalán \& Oliveira, 2005). Essa superfície de aplainamento regional foi denominada de Japi por Almeida (1958, apud Almeida \& Carneiro, 1998). Datação de rocha alcalina efusiva subaérea derramada sobre a Superfície Japi na região do Graben da Guanabara, Rio de Janeiro, revela idade de $65,65 \pm 0,05$ Ma pelo método ${ }^{40} \mathrm{Ar} /{ }^{39} \mathrm{Ar}$ (Riccomini et al., 2004), fato que reforça a interpretação apresentada para o intervalo de tempo de sua formação.

$\mathrm{O}$ contexto de um mega-platô adjacente às subsidentes bacias de Santos e Campos acabou por criar uma situação isostaticamente instável. Reativação tectônica gerada por colapso gravitacional iniciou-se por volta de 7 milhões de anos após o limite Cretáceo-Paleógeno, de tal modo que do final do Paleoceno até o início do Mioceno ( 59-20 Ma, Cohen et al., 2013), a crosta continental se quebrou, muitas vezes aproveitando zonas de fraqueza brasilianas de direção geral NE-SW, na região. Tal evento acabou por deformar a Superfície Japi em uma série de grabens e horsts relativamente paralelos à zona axial da Faixa Ribeira e também à atual linha de costa da região sudeste (Trouw et al., 2000; Zalán \& Oliveira, 2005).

Cogné et al. (2011) estimaram a quantidade total de denudação para essa região a partir de termocronologia de baixa temperatura. Segundo eles, houve exumação de pelo menos $4 \mathrm{~km}$ próximo à costa, e este valor decresce em direção ao interior do continente. Os autores ressaltam ainda que muitas das taxas de denudação local inferidas por meio de traços de fissão em apatita, apresentaram picos do Cretáceo Superior ao Cenozóico, fato também observado nos trabalhos de Cobbold et al. (2001) e Hackspacher et al. (2008). 
Em abordagem um pouco distinta, Almeida \& Carneiro (1998) procuram analisar os mecanismos que governaram a origem e evolução da Serra do Mar a partir da Falha de Santos que, segundo os autores, na região do presente estudo é situada na plataforma continental entre a ilha de São Sebastião e o continente (ver mapa da figura 2.1). Para esses autores, o soerguimento progressivo regional associado a intrusões e diques alcalinos, que atuou no Coniaciano-Maastrichtiano ( 90-66 Ma, Cohen et al., 2013), teria sido impulsionado por efeito de compensação isostática entre as bacias marginais, em afundamento, e a área continental, em ascensão e erosão (Asmus \& Guazelli, 1981, apud Almeida \& Carneiro, 1998; Macedo, 1991,). Posteriormente, o evento tectônico que teve início no Paleoceno e causou a deformação por flexura e falhamento da Superfície Japi, dando origem às bacias tafrogênicas do Sudeste e à Serra da Mantiqueira, também fez surgir a Serra do Mar na área da atual plataforma continental, por soerguimento do bloco ocidental da Falha de Santos e abatimento do oriental, este coberto por sedimentos marinhos cenozóicos. No decorrer de 30-40 milhões de anos o processo de erosão diferencial regressiva fez com que as encostas da Serra do Mar recuassem até sua posição atual. Desse modo, os autores enfatizam que o atual flanco leste da Serra do Mar não apresenta evidências de ter sido resultado de falhamento proeminente.

Entretanto, em discussão sobre a Falha de Santos, Zalán \& Oliveira (2005) relatam que, por meio da análise de mapas de métodos potenciais, não encontraram indícios da existência da falha, tal como proposta por Almeida \& Carneiro (1998). Ao contrário do que é proposto por estes autores, Zalán \& Oliveira (2005) indicam que a falha que limita a ilha de São Sebastião, a norte (ver mapa da figura 2.1), apresenta o bloco ocidental rebaixado, constituindo extensão da falha de borda de um graben cenozóico inferido por eles na plataforma continental rasa.

Em contraste às interpretações apresentadas até então, os trabalhos de Riccomini (1989), Cobbold et al. (2001), Riccomini et al. (2004) e Cogné et al. (2013) propõem visão distinta em relação ao contex to tectônico dos mecanismos formadores e modificadores do Sistema de Riftes Cenozóicos do Sudeste do Brasil. Por meio de análise estrutural de planos de falha estriados, juntas e dobras, Riccomini (1989) defende que esse sistema tenha sido formado no Paleógeno por extensão NW-SE, e então reativado no Neógeno por transpressão destral. Cobbold et al. (2001) favorecem origem transtrativa durante o Paleógeno e reativação transpressiva durante o Neógeno, ambas em resposta às tensões de campo distante. Riccomini et al. (2004) sugerem episódios de extensão com direção NNW-SSE a E-W, alternados com episódios de reativação compressiva de direção NW-SE a E-W. Essa oscilação, segundo os autores, foi atribuída ao 
delicado balanço entre o slab-pull na trincheira do Pacífico e o ridge-push na dorsal MesoAtlântica.

De qualquer forma, a ocorrência desses grabens/bacias e corpos intrusivos alcalinos representa boa evidência de ativação pós-rifte e, como assinalam Cogné et al. (2011), levantam a questão da extensão e intensidade dessa atividade ao longo da margem continental e do continente adentro.

\subsubsection{Graben de Taubaté}

Entre os riftes gerados pelo evento cenozóico está o Rifte do Paraíba do Sul (Zalán \& Oliveira, 2005), localizado no nordeste do Estado de São Paulo e no sul-sudoeste do Estado do Rio de Janeiro. Esse rifte encaixa completamente o curso do rio homônimo, e nele ocorrem, de sudoeste para nordeste, os grabens de São Paulo, Taubaté, Queluz, Resende-Volta Redonda e do Baixo Paraíba do Sul, com suas respectivas coberturas sedimentares (bacias) associadas, exceto pelo último, que não apresenta acumulações sedimentares significativas. A individualização dessas bacias está relacionada a fases de deformação posteriores à implantação do segmento central do Sistema de Riftes Cenozóicos do Sudeste do Brasil, como evidenciado por ocorrências isoladas de sedimentitos nas áreas entre as mesmas (Riccomini, 1989).

O Graben de Taubaté, cujo extremo meridional é atravessado pelo perfil sísmico PABBRISE (ver mapa da figura 2.1), é fortemente assimétrico e possui estilo estrutural de tectônica tipo-dominó. Sua borda setentrional falhada ocorre junto ao sopé da Serra da Mantiqueira, enquanto sua borda meridional, também falhada, é admitida no limite com a Serra do Mar (Zalán \& Oliveira, 2005).

O depósito sedimentar do graben é denominado de Bacia de Taubaté, a mais expressiva entre as que compõem os vales tectônicos cenozóicos supracitados. Seu preenchimento pode ser dividido em duas fases: a sequência sin-rifte do Grupo Taubaté, e a sequência pós-rifte da Formação Pindamonhangaba, com depósitos aluvionares/coluvionares associados (Riccomini, 1989).

O arcabouço da Bacia de Taubaté é composto por subgrabens separados por falhas de transferência ou zonas de acomodação, com depocentros invertidos, em típica geometria de bacia do tipo rifte. A sedimentação foi essencialmente continental, o que resultou em pacote sedimentar com espessura máxima de 800-850 m próximo à porção centro-nordeste da bacia 
(Riccomini, 1989; Marques, 1990; Riccomini et al., 2004; Carvalho et al., 2011; Cogné et al., 2013;). Em sua porção sudoeste, atravessada pelo perfil sísmico, o pacote sedimentar não ultrapassa $200 \mathrm{~m}$ de espessura (Carvalho et al., 2011). Zalán \& Oliveira (2005) indicam que o rejeito do embasamento na borda setentrional da Bacia de Taubaté, limite com a Serra da Mantiqueira, é da ordem de $2.500 \mathrm{~m}$.

Recentemente, após análise de afloramentos e perfis sísmicos da Bacia de Taubaté, Cogné et al. (2013) sugerem que a mesma seja do tipo afastamento (pull-apart), formada durante o Paleógeno sob tensões transtrativas, com o principal tensor horizontal na direção NESW. Após período de quiescência (Oligoceno ao início do Mioceno), a bacia foi reativada durante o Neógeno sob esforços transpressivos, com o principal tensor horizontal com direção aproximadamente E-W. Esses autores buscam correlacionar as variações na direção dos principais tensores da bacia às amplas tensões acumuladas pela Placa Sul-Americana devido à Orogenia Andina. No entanto, os mesmos ressaltam que ainda é uma questão em debate se esses esforços compressivos são capazes de se propagar e afetar, de maneira efetiva, a região sudeste do Brasil. 


\section{CAPÍTULO 3 - FUNDAMENTAÇÃO TEÓRICA DOS MÉTODOS UTILIZADOS}

A teoria dos métodos sísmicos é baseada nos conceitos de propagação de ondas elásticas. Onda é definida como um fenômeno periódico que transporta energia mediante perturbação em meio elástico ou campo oscilante, sendo classificada como onda mecânica ou eletromagnética. As ondas sísmicas são ondas mecânicas que se propagam em meios elásticos. São subdivididas em ondas de superfície ou de corpo, estas subdivididas em compressivas (longitudinais, P) ou cisalhantes (transversais, S). Como qualquer onda, as ondas sísmicas podem ser transmitidas, refratadas e refletidas. A partir disto, é possível utilizá-las para investigar as propriedades e estrutura do meio, neste caso, do planeta Terra.

Investigações utilizando propagação de ondas sísmicas geradas a partir de fontes controladas vêm sendo realizadas pelo menos desde a segunda metade do século XIX (Prodehl \& Mooney, 2012). No entanto, prospecções geofísicas por meio da aplicação de uma variação do método de refração sísmica e o uso de explosões, os chamados "eventos artificiais controlados", como fontes de energia para estudos crustais tiveram início apenas a partir das primeiras décadas do século XX, devido aos avanços tecnológicos alcançados durante a Primeira Guerra Mundial. Posteriormente, ao final da Segunda Guerra Mundial, foram iniciados os primeiros estudos sistemáticos da crosta terrestre e, nas duas décadas seguintes (1950-1960), houve avanços significativos no desenvolvimento de instrumentos e procedimentos específicos alinhados com as práticas atuais (Green, 1974; Prodehl et al., 2013).

\subsection{O método sísmico de refração/reflexão de ângulo amplo (WARR)}

O método sísmico de refração/reflexão de ângulo amplo (WARR, do inglês: wide-angle reflection/refraction) utiliza fontes controladas (explosões/tiros ou unidades móveis de percussão/vibração) e arranjo de receptores (sensores), ambos com espaçamento relativamente regular em perfil para, respectivamente, gerar e registrar oscilações mecânicas (ondas sísmicas). Estas interagem com o meio em cujas interfaces internas são transmitidas, refratadas e refletidas. As porções refratadas e refletidas retornam à superfície e geram alinhamentos de fases sísmicas em curvas tempo-distância que, por sua vez, são utilizados, por meio do cálculo da distribuição de seus tempos de trânsito e outras propriedades sísmicas ao longo do perfil, 
para traduzir as características físicas e estruturais do meio que percorreram, neste caso, a crosta continental e o manto superior (Figura 3.1).

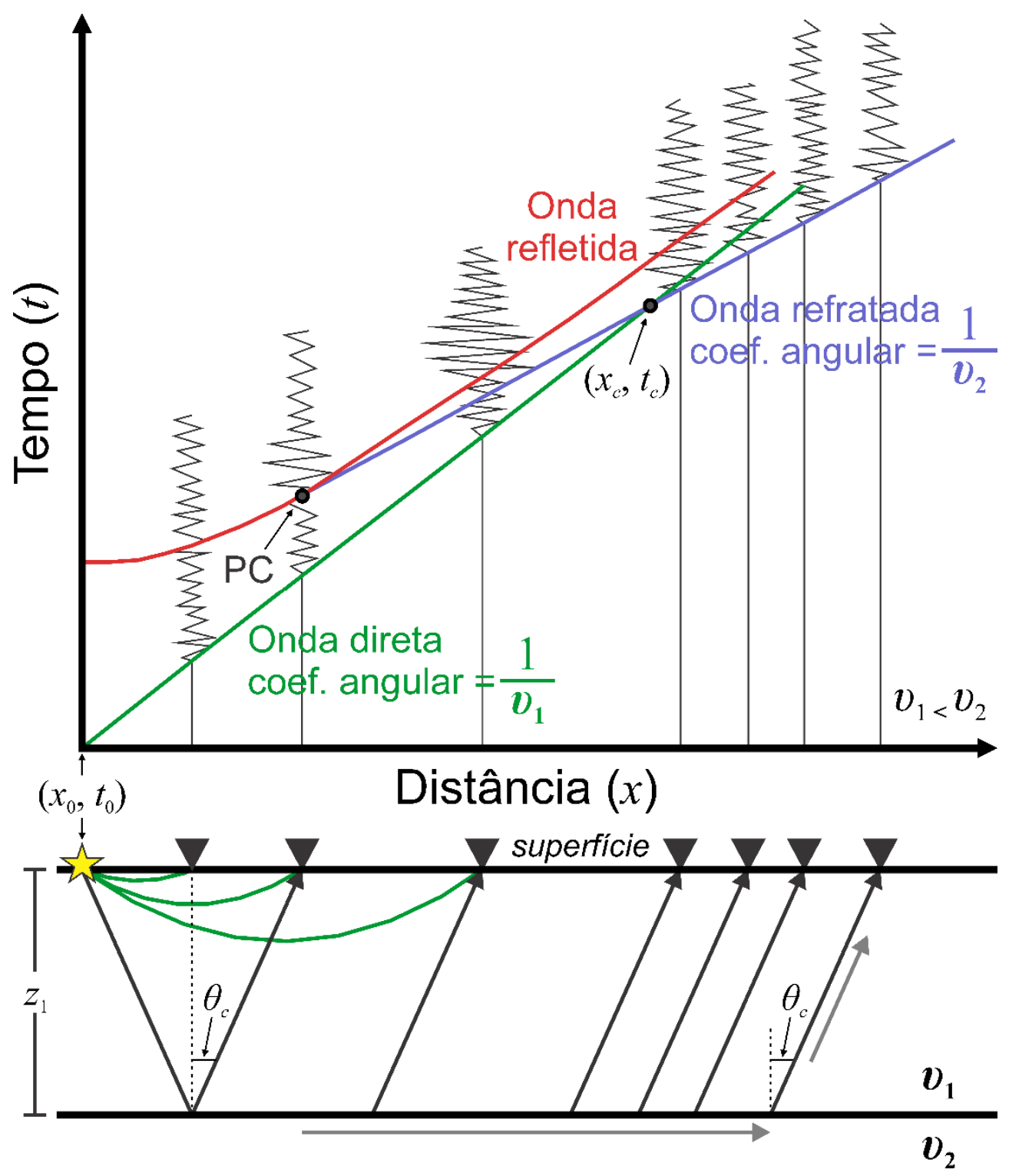

Figura 3.1 Sismograma hipotético mostrando as relações das curvas tempo-distância entre as ondas direta, refratada e refletida para um modelo de uma interface. A estrela representa explosão controlada. Os triângulos representam sensores em superfície. A onda direta é uma reta que passa pela origem dos eixos $\left(x_{0}, t_{0}\right)$ e com coeficiente angular igual ao inverso da velocidade da primeira camada. A onda refletida é uma hipérbole assíntota à onda direta para grandes distâncias $x$. A onda refratada é uma reta com início a partir da incidência crítica da frente de onda ( $\mathrm{PC}$ - ponto crítico). Nesse ponto a refração e a reflexão são tangentes. O ponto $\left(x_{c}, t_{c}\right)$ é definido como ponto de "crossover", onde dois alinhamentos de ondas refratadas se interceptam (adaptado de Soares, 2005).

O método pode ser utilizado desde problemas estruturais a estudos geológicos e tectônicos. Estes, por sua vez, podem envolver perfis de dezenas de metros a centenas de 
quilômetros. A diferença não é uma questão de princípio, mas de escala (Green, 1974), ou seja, a extensão de um arranjo de fontes e sensores é baseada nos objetivos de cada levantamento, principalmente na profundidade de interesse a ser atingida. De maneira geral, em estudos crustais são utilizados arranjos com extensão de sete a dez vezes maiores do que a profundidade visada para investigação (Soares, 2005).

O método tem contribuído para o estudo da crosta continental e do manto superior por permitir bom controle da distribuição do campo de velocidade das ondas sísmicas no meio, e consequentemente, um bom controle da profundidade das descontinuidades mais expressivas da litosfera como, por exemplo, o limite sísmico/sismológico entre a crosta e o manto, ou seja, a descontinuidade de Mohorovičić (Mohorovičić, 1910, apud Prodehl et al., 2013), comumente referida como a "Moho", em homenagem ao seu primeiro observador, o cientista croata Andrija Mohorovičić.

Como apontado por Green (1974), há três condições básicas necessárias para que a perturbação mecânica percorra a distância da fonte controlada (ponto de tiro) até os receptores (estações-sensores) ao longo de caminhos de raios:

- A velocidade sísmica deve aumentar com a profundidade, $v_{n}>v_{n-1}>\ldots>v_{1}$. Onde $v$ é a velocidade de cada camada hipotética. Tal condição pode parecer demasiado restritiva, mas na maioria dos casos ela é sustentada (Green, 1974);

- A espessura de cada camada deve ser pequena em comparação com a extensão do arranjo de sensores;

- A espessura de cada camada deve ser grande em comparação com os comprimentos de onda predominantes da onda sísmica em propagação.

Satisfeitas essas condições, o fenômeno sísmico pode ser discutido geometricamente em termos da teoria do raio sísmico, havendo pouca necessidade de se introduzir a complexidade proveniente da teoria de ondas (Green, 1974).

A teoria do raio sísmico (Červený et al., 1977; Červený, 2001, e referências ali contidas) é aplicada na interpretação de dados sísmicos há mais de um século. Isto se deve à sua simplicidade e aplicabilidade em uma variedade de problemas (Shearer, 2009). A teoria tem como base o cálculo do tempo de trânsito de raios sísmicos através de um determinado meio.

No caso mais simples, o de uma camada homogênea, isotrópica e horizontal, de espessura $z_{1}$, e velocidade $v_{1}$, sobreposta a um meio-espaço também isotrópico e de velocidade $v_{2}$, de maneira que todo o conjunto satisfaça as três condições básicas supracitadas (por 
exemplo, $v_{1}<v_{2}$ ), a partir da Figura 3.1, por relações geométricas simples, o tempo de propagação $t_{1}$ para o raio direto é dado por

$$
t_{1}=\frac{x}{v_{1}}
$$

onde $x$ representa a distância horizontal do último receptor em análise ao ponto de tiro $\left(x_{0}, t_{0}\right)$ em questão.

A inclinação da reta definida pela equação (3.1) é dada por

$$
\frac{d t_{1}}{d x}=\frac{1}{v_{1}}
$$

Consequentemente, a velocidade da camada, $v_{1}$, pode ser determinada. Ela corresponde ao coeficiente angular da reta que representa o alinhamento de fases da onda direta.

O tempo de propagação, $t_{2}$, para o raio refratado é dado por

$$
t_{2}=\frac{x}{v_{2}}+2\left(\frac{z_{1}}{v_{1}}\right) \cos \theta_{c}
$$

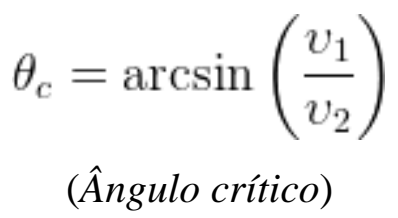

O ângulo crítico, $\theta_{c}$, representa, geometricamente, o maior ângulo de incidência possível que ainda resulta em um raio refratado.

A inclinação da reta definida pela equação (3.3) é dada por

$$
\frac{d t_{2}}{d x}=\frac{1}{v_{2}}
$$


Portanto, a velocidade do meio-espaço, v2, também pode ser determinada. Corresponde ao coeficiente angular da reta que representa o alinhamento de fases da refração entre a camada e o meio-espaço (ver Figura 3.1).

A distância, $x_{c}$, e o tempo, $t_{c}$, em que os raios direto e refratado se interceptam são denominados de distância crítica e tempo crítico, respectivamente (ver Figura 3.1). A partir de sua utilização, a espessura $z_{1}$ da camada pode ser determinada:

$t_{c}=\frac{x_{c}}{v_{2}}+2\left(\frac{z_{1}}{v_{1}}\right) \cos \theta_{c}$

(Equação 3.5)

Também de suma importância, a equação tempo-distância para um raio refletido na base de qualquer camada horizontal e isotrópica é definida por

$$
t^{2}=\frac{x^{2}}{\bar{v}^{2}}+\frac{(2 z)^{2}}{\bar{v}^{2}}
$$

Com a linearização da equação da reflexão (método $x^{2}-t^{2}$ ), é possível obter a velocidade média do meio acima do refletor, $\bar{v}$, e a profundidade $z$ do refletor em análise.

Para um caso mais complexo no qual ocorrem múltiplas camadas horizontais, $(n-1)$, a equação tempo-distância para a (n-1)-ésima refração passa a ser dada por

$$
t_{n}=\frac{x}{v_{n}}+2 \sum_{k=1}^{n-1} \frac{z_{k}}{v_{k}} \cos \theta_{c}
$$

As relações geométricas e suas respectivas equações, aqui apresentadas de maneira simplificada, formam a base para a abordagem e interpretação de dados sísmicos do tipo WARR. Dificuldades na interpretação desse tipo de dados surgem, em grande parte, da complexidade inerente ao meio geológico como, por exemplo, a inversão de velocidade sísmica, e a existência de camadas inclinadas e falhas, que complicam o comportamento das curvas tempo-distância e exigem experiência do intérprete. O objetivo é formar um modelo inicial que posteriormente será refinado na modelagem direta utilizando o método do traçado de raios. 


\subsection{O traçado de raios por meio do pacote de programas RAYINVR}

Um dos problemas mais comuns e desafiadores em estudos sísmicos e sismológicos é o da predição do caminho fonte-receptor tomado pela energia sísmica na presença de um meio lateralmente heterogêneo. A solução desse problema é necessária para muitas aplicações, dentro e fora da sismologia. Nas últimas décadas, a crescente necessidade da previsão rápida e precisa das propriedades da onda sísmica gerou inúmeros algoritmos baseados em grades (grids) ou no método de traçado de raios (Rawlinson et al., 2007). Este último foi utilizado no presente trabalho por ser um método tradicional, computacionalmente eficiente e preciso, e naturalmente capaz de proporcionar a predição de várias propriedades da onda sísmica, principalmente o tempo de trânsito.

O procedimento de resolução de um sistema de traçado de raios é denominado de método de traçado de raios (Červený et al., 1977; Červený, 2001, e referências ali contidas). O método é utilizado para simplificar o cálculo do caminho que uma onda percorre através de um meio com regiões de diferentes velocidades de propagação. Essa questão é resolvida ao assumir que cada onda possa ser modelada como um conjunto de feixes estreitos (raios) que avançam através do meio por distâncias discretas, e repetidamente passam por ajustes, por intermédio de derivadas locais do meio, para o cálculo de suas novas direções de propagação, até que um caminho de raio completo seja traçado, por exemplo, de uma fonte a um receptor.

O algoritmo empregado neste trabalho para o cálculo do traçado de raios em um meio bidimensional parametrizado foi desenvolvido por Zelt \& Ellis (1988), e posteriormente aperfeiçoado e incorporado ao pacote de programas RAYINVR, desenvolvido por Colin A. Zelt (Zelt \& Smith, 1992). O RAYINVR é um pacote de programas utilizado para o traçado de raios em meio 2-D, inversão do tempo de trânsito de ondas, cálculo de amplitudes e de sismogramas sintéticos. No presente trabalho foi utilizado o programa de traçado de raios.

A parametrização de um modelo 2-D para o cálculo do traçado de raios consiste na criação de camadas ao longo do modelo, estas são divididas em blocos trapezoidais baseados em interpolação linear em que um número mínimo de parâmetros independentes é necessário para a representação de modelos típicos de crosta e manto superior. O número e a posição desses parâmetros independentes, nós de velocidade e profundidade que especificam cada camada, podem ser adaptados de acordo com a necessidade, resolução e qualidade dos dados, e também permitem que afinamento progressivo de camadas (pinch-outs) e o relevo superficial sejam incorporados ao modelo (Zelt \& Smith, 1992). 
Em exemplo simplificado, para um único trapezóide com quatro arestas definidas no plano $x-z$ (Figura 3.2) por

$$
x=x_{1}, \quad x=x_{2}, \quad z=s_{1}+b_{1}, \quad z=s_{2}+b_{2},
$$

e quatro vértices de velocidade $v_{1}, v_{2}, v_{3}$ e $v_{4}$. A velocidade da onda $\mathrm{P}$ no ponto $v(x, z)$ dentro do trapezóide é definida por

$$
v(x, z)=\frac{\left(c_{1} x+c_{2} x^{2}+c_{3} z+c_{4} x z+c_{5}\right)}{\left(c_{6} x+c_{7}\right)}
$$

onde os coeficientes $c_{i}$ representam combinações lineares das velocidades $v_{i}$ dos vértices (Equação 2; Zelt \& Smith, 1992). Os coeficientes são pré-calculados para todos os trapezóides anteriormente ao traçado de raios.

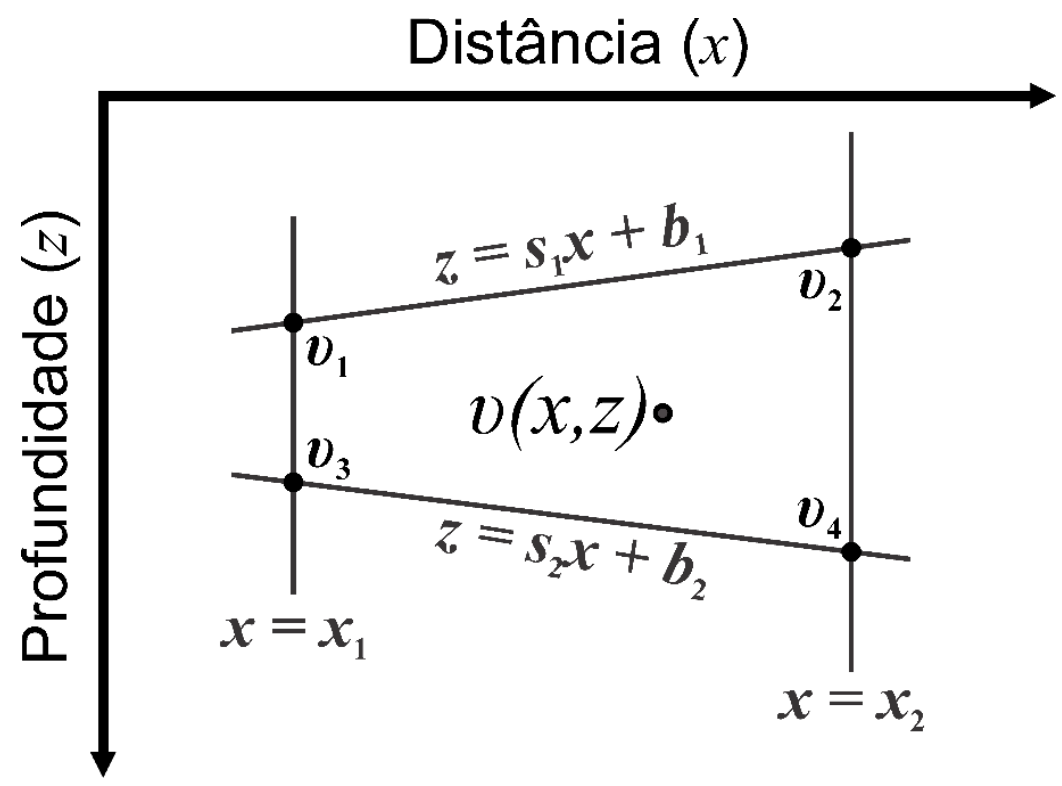

Figura 3.2 A distribuição de velocidade $v(x, z)$, dada pela equação (3.8) dentro de um trapezóide de modelo hipotético parametrizado (adaptado de Zelt \& Smith, 1992).

Os parâmetros independentes, ou seja, os nós de velocidade e profundidade do modelo, podem ser analisados e editados de maneira rápida e interativa por intermédio do programa 
vmed, desenvolvido por Barry C. Zelt (código-fonte, documentação e exemplos estão disponíveis em http://www.soest.hawaii.edu/users/bzelt/vmed/vmed.html).

Após a parametrização do modelo de velocidade, os raios são traçados pelo RAYINVR (Zelt \& Smith, 1992) com o uso da teoria do raio assintótico de ordem zero por meio da solução numérica das equações do traçado de raios (Červený et al., 1977; Červený, 2001, e referências ali contidas). O tamanho do avanço do raio traçado é automaticamente ajustado em cada iteração para maximizar a eficiência dos cálculos enquanto a precisão é mantida. Os tempos de trânsito são calculados por integração ao longo da trajetória dos raios (Zelt \& Ellis, 1988).

As equações do traçado de raios em meio 2-D são representadas por um par de equações diferenciais ordinárias de primeira-ordem que podem ser escritas de duas formas (Zelt \& Smith, 1992):

$$
\frac{d z}{d x}=\cot \Theta, \quad \frac{d \Theta}{d x}=\frac{\left(v_{z}-v_{x} \cot \Theta\right)}{v}
$$

ou

$$
\frac{d x}{d z}=\tan \Theta \quad \frac{d \Theta}{d z}=\frac{\left(v_{z} \tan \Theta-v_{x}\right)}{v}
$$

Com condições iniciais:

$$
x=x_{0}, \quad z=z_{0}, \quad \Theta=\Theta_{0}
$$

A variável $\Theta$ é o ângulo entre a tangente ao raio e o eixo $z, x$ é a velocidade da onda, $v_{x}$ e $v_{z}$ são derivadas parciais da velocidade em relação às coordenadas $x$ e $z$ (positivo para baixo), respectivamente. O ponto $\left(x_{0}, z_{0}\right)$ é a localização da fonte (ponto de tiro) e o ângulo de partida do raio é dado por $\Theta_{0}$. Um método do tipo Runge-Kutta com controle de erro é utilizado para a resolução dos sistemas de equações (3.9a) ou (3.9b). A utilização de um sistema em detrimento ao outro depende unicamente da orientação do caminho do raio no momento da integração: sistema (3.9a) para caminhos quase-horizontais e (3.9b) para caminhos quase-verticais. Para completar o algoritmo básico de traçado de raios, a lei de Snell (Equação 3.10) é aplicada na intersecção de um raio com a interface entre quaisquer camadas (Zelt \& Smith, 1992). 


$$
\frac{\sin \alpha_{1}}{v_{1}}=\frac{\sin \alpha_{2}}{v_{2}} \equiv p
$$

onde $p$ representa a constante do parâmetro de raio.

A lei de Snell descreve a relação entre os ângulos de incidência e refração, neste caso, de raios sísmicos passando através de uma interface entre duas camadas distintas. $\alpha_{1}$ e $\alpha_{2}$ são os ângulos de incidência e refração, respectivamente. Esta relação é dependente da respectiva velocidade, $v$, de cada camada. Se a velocidade da camada sotoposta, $v_{2}$, for maior do que a velocidade da camada acima dela, $v_{1}$, como na maioria dos casos geológicos, o raio refratado se afasta do eixo normal às camadas. 


\section{CAPÍTULO 4 - AQUISIÇÃO E PROCESSAMENTO DOS DADOS}

\subsection{Aquisição dos dados: o experimento sísmico}

Os dados sísmicos PABBRISE foram adquiridos em levantamento realizado nos meses de outubro e novembro de 2013, ao longo de perfil de aproximadamente $700 \mathrm{~km}$ de extensão na direção NW-SE. O perfil está integralmente inserido no Estado de São Paulo, com início no município de Santa Clara D’Oeste, próximo à barranca do Rio Paraná, e final em Caraguatatuba, litoral norte paulista. Foram utilizadas 347 estações receptoras (pares sensorregistrador), uma instalada aproximadamente a cada 2,0 km e 13 explosões controladas (ponto de tiro - PT), uma aproximadamente a cada $50 \mathrm{~km}$ ao longo do perfil, com exceção do PT-10, alocado em pedreira entre as cidades de Rio Claro e Ipeúna, e o espaço entre os tiros PT-11 e PT-15, estes espaçados de 100 km devido à ausência dos tiros PT-12 e PT-14, inviabilizados por motivos burocrático e técnico, respectivamente (ver Figura 1.1, Capítulo 1).

A aquisição dos dados consistiu em duas etapas principais: viabilização logística preparatória e a aquisição sísmica propriamente dita. Detalhamento técnico e instrumental relativos à aquisição de dados do tipo WARR para estudos crustais profundos, e semelhantes ao aplicados aqui, são apresentados no capítulo 3 de Lima (2011).

A viabilização logística é a etapa preparatória que antecede a aquisição sísmica dos dados. Ela teve por finalidade o reconhecimento primário da área onde o experimento foi realizado, bem como na determinação, em mapa e em campo, dos locais onde foram instaladas as estações receptoras e onde foram realizadas as explosões por fontes controladas, a fim de checar a acessibilidade aos locais previstos e, se necessário, determinar ponto alternativo próximo. Nesta etapa também foram obtidas as autorizações legais, por parte de cada proprietário de terra, para a perfuração dos poços onde foram efetuadas as explosões controladas, bem como o ciente da administração pública de cada munícipio em que tiros foram programados e, por último, a autorização do Exército, necessária para o manejo e utilização de explosivos.

A etapa de aquisição sísmica propriamente dita teve a duração de 15 dias e envolveu a participação de 7 equipes de campo responsáveis pela instalação das estações receptoras, e 2 grupos de apoio técnico-operacional responsáveis pela programação dos instrumentos, preenchimento dos poços com emulsão explosiva e realização dos tiros, totalizando efetivo de quase 40 participantes. As equipes de campo foram constituídas por alunos, técnicos e 
motoristas do IG/UnB, IAG/USP, INPE e UNIPAMPA. Os grupos de apoio técnicooperacional foram compostos por professores, técnicos e motoristas dessas mesmas instituições, além de técnicos das empresas CNM Fuad Rassi e Britanite, responsáveis pela perfuração dos poços e realização das explosões controladas, respectivamente. Nesta etapa foi estabelecida base de apoio logístico-operacional em um condomínio entre as cidades de Rio Claro e Ipeúna, próximo ao PT-10.

Os principais equipamentos utilizados para a realização da aquisição de dados do perfil sísmico PABBRISE foram os seguintes:

a) 315 registradores digitais monocanal (marca REF TEK, modelo Texan 125A);

b) 315 sensores sísmicos analógicos verticais, 2 Hz/0,5 s, 5500 ohms (marca Sercel, modelo L-4A);

c) 32 registradores digitais de 3 canais (marca REF TEK, modelo DAS130-01/3);

d) 32 sensores sísmicos analógicos triaxiais, $2 \mathrm{~Hz} / 0,5 \mathrm{~s}, 5500 \mathrm{ohms}$ (marca Sercel, modelo L-4-3D).

Todos os equipamentos fazem parte do Pool de Equipamentos Geofísicos do Brasil (PEGBr), concebido no âmbito da Rede de Estudos Geotectônicos Petrobras-Universidades (RGEOTEC) e administrado pelo Observatório Nacional, no Rio de Janeiro (ON/MCT) (informações, normas, lista de equipamentos e projetos atendidos podem ser visualizados no endereço http://www.pegbr.on.br).

As estações triaxiais, itens c) e d) da lista de equipamentos, também foram utilizadas em outro experimento associado ao presente projeto de pesquisa. Este experimento contou com total de 37 estações triaxiais de período curto, uma aproximadamente a cada $20 \mathrm{~km}$, em arranjo ao longo do perfil sísmico PABBRISE. Elas ficaram em campo no período de 13/08/2013 a 29/11/2013 e foram utilizadas por Peixoto (2015) com o propósito de aplicar a técnica de função do receptor em registros de telessismos para definir a espessura e $\mathrm{Vp} / \mathrm{Vs}$ médias da crosta sob cada estação e, posteriormente, comparar o resultado obtido por modelagem sintética desses resultados com o modelo sísmico final. A instalação ao longo do perfil sísmico PABBRISE possibilitou o aproveitamento dos registros da componente vertical de 32 dessas estações para compor parte do banco de dados sísmicos do presente trabalho.

Nos registradores digitais monocanal (Texan 125A) foi utilizada taxa de amostragem de 200 amostras por segundo, enquanto que nos registradores digitais de 3 canais (DAS130) foi utilizada taxa de 100 amostras por segundo, posteriormente reamostrada para 200 amostras por 
segundo. A maior parte dos instrumentos foi instalada próxima a estradas secundárias e fora de perímetros urbanos com a finalidade de minimizar o registro de ruídos antrópicos.

As fontes controladas foram alocadas em treze poços de 10" de diâmetro e com aproximadamente $45 \mathrm{~m}$ de profundidade cada. $\mathrm{O}$ explosivo utilizado foi a emulsão química bombeável Ibemux, da Britanite. A emulsão foi acomodada nos dois terços inferiores do poço, e o terço superior obstruído com brita. Localização e parâmetros das fontes explosivas utilizadas ao longo do perfil PABBRISE podem ser conferidos na Tabela 1.

Tabela 4.1 Localização e parâmetros das fontes explosivas utilizadas ao longo do perfil PABBRISE.

\begin{tabular}{|c|c|c|c|c|c|c|}
\hline $\begin{array}{c}\mathbf{N}^{\circ} \text { do } \\
\text { ponto } \\
\text { de tiro }\end{array}$ & $\begin{array}{c}\text { Distância } \\
\mathbf{( k m )}\end{array}$ & $\begin{array}{c}\text { Lat } \mathbf{N} \boldsymbol{\varphi} \\
\mathbf{( g r a u )}\end{array}$ & $\begin{array}{c}\text { Long E } \mathbf{\lambda} \\
\mathbf{( g r a u )}\end{array}$ & $\begin{array}{c}\text { Elevação } \\
\mathbf{h}(\mathbf{m})\end{array}$ & $\begin{array}{c}\text { Hora-origem UTC } \\
\text { (a:d:h:m:s) }\end{array}$ & $\begin{array}{c}\text { Carga } \\
\text { TNT } \mathbf{( k g})\end{array}$ \\
\hline PT-01 & 2,257 & $-20,10556$ & $-50,97233$ & 339 & $2013: 300: 03: 02: 07,663$ & 4.500 \\
\hline PT-02 & 56,672 & $-20,41734$ & $-50,56738$ & 409 & $2013: 303: 03: 16: 19,683$ & 450 \\
\hline PT-03 & 106,844 & $-20,68258$ & $-50,17641$ & 465 & $2013: 300: 03: 16: 03,419$ & 1.500 \\
\hline PT-04 & 153,172 & $-20,92875$ & $-49,81635$ & 407 & $2013: 300: 05: 16: 03,382$ & 1.500 \\
\hline PT-05 & 205,448 & $-21,19457$ & $-49,40003$ & 425 & $2013: 307: 00: 30: 40,400$ & $\sim 2.400$ \\
\hline PT-06 & 253,301 & $-21,42538$ & $-49,00897$ & 459 & $2013: 300: 05: 31: 00,320$ & 800 \\
\hline PT-07 & 305,258 & $-21,69809$ & $-48,60075$ & 549 & $2013: 301: 03: 00: 59,570$ & 1.500 \\
\hline PT-08 & 347,624 & $-21,83772$ & $-48,20685$ & 636 & $2013: 301: 05: 01: 00,498$ & 1.500 \\
\hline PT-09 & 405,357 & $-22,17204$ & $-47,77397$ & 820 & $2013: 301: 03: 16: 11,094$ & 1.500 \\
\hline PT-10 & 429,999 & $-22,38414$ & $-47,64140$ & 612 & $2013: 301: 05: 16: 55,223$ & 4.500 \\
\hline PT-11 & 510,094 & $-22,71198$ & $-46,93848$ & 666 & $2013: 301: 03: 31: 08,690$ & 1.500 \\
\hline PT-13 & 605,472 & $-23,19395$ & $-46,16774$ & 734 & $2013: 302: 03: 01: 00,213$ & 1.500 \\
\hline PT-15 & 690,964 & $-23,62365$ & $-45,47287$ & 33 & $2013: 303: 03: 01: 08,487$ & 890 \\
\hline
\end{tabular}

Com exceção do PT-05, todas as outras explosões controladas foram realizadas nos dias e horários previstos para o experimento. Os tiros foram durante a madrugada, entre 00:00 e 05:30 horas, horário local, com a finalidade de minimizar o ruído antrópico (veículos, indústrias e outras atividades humanas) nos registros. A detonação do PT-05 foi prejudicada por problemas técnicos da equipe de fogo e teve de ser realizada após o final da etapa de aquisição sísmica, quando já não havia mais estações monocanal instaladas. Devido a isto, apenas as estações triaxiais, que são espaçadas de $\sim 20 \mathrm{~km}$ e permaneceram instaladas em campo, registraram o sinal proveniente da explosão controlada do PT-05.

O controle da hora de origem de cada explosão foi realizado por meio de dispositivo semelhante ao descrito por Lima (2011). O dispositivo é alocado próximo à explosão controlada e consiste em um fio paralelo (dois fios encapados) associado a um circuito (com LED) fechado. Uma das extremidades do fio é colocada junto ao explosivo (ou booster), a outra é ligada ao 
par de fios que sai do circuito, fechando-o, e este então é conectado a um registrador DAS130 com taxa de amostragem de 500 amostras por segundo, para a digitalização do sinal de interesse. Antes da explosão, com o circuito ainda fechado, o sinal registrado tem o valor em torno de 1,7-2,1 V, o que corresponde à tensão de polarização do LED. No instante da explosão controlada, o circuito é rompido e a tensão do sinal cai a zero (o LED se apaga). O sinal digital obtido pelo DAS130 registra a queda de tensão brusca como a hora de origem da explosão controlada e com precisão de $\pm 2 \mathrm{~ms}$.

Após a aquisição dos dados sísmicos, as estações monocanal foram recolhidas e encaminhadas à base de apoio logístico-operacional, onde foi dado início à etapa de processamento dos dados.

\subsection{Processamento dos dados: geração das seções sísmicas}

A etapa de processamento dos dados adquiridos foi iniciada ao final do levantamento, ainda em campo, pelos professores José Eduardo P. Soares (UnB) e Marcus Vinícius A. G. de Lima (UNIPAMPA) e, posteriormente, finalizada pelo mestrando. Esta etapa consistiu na aplicação de cinco procedimentos básicos para preparação dos dados para a geração das seções sísmicas finais para cada um dos pontos de tiro (PT-01-11, 13 e 15).

O primeiro procedimento aplicado foi o da correção do tempo de deriva (drift) instrumental dos registradores Texan 125A - os verticais. Estes registradores digitais monocanal não operam com antenas receptoras GPS em campo. Devido a isto, eles possuem relógios internos que são sincronizados quando conectados a um computador com antena receptora de GPS em dois momentos distintos: durante sua programação, antes da instalação das estações em campo e, ao final da etapa de aquisição, quando do download dos dados. As correções de tempo foram aplicadas assumindo a deriva instrumental linear. Para o caso dos registradores de 3 canais (DAS130) não há a necessidade de correção do tempo de deriva instrumental devido ao fato das estações triaxiais operarem com antena receptora GPS em campo, de modo que a deriva é constantemente verificada e corrigida automaticamente.

O segundo procedimento consistiu na conversão dos dados brutos de cada registrador, ou seja, cada traço sísmico, para o formato SAC (Seismic Analysis Code). Este é um pacote de programas para o estudo de sinais sequenciais, principalmente com aplicações em sísmica e sismologia. (O SAC foi desenvolvido no Lawrence Livermore National Laboratory, Estados 
Unidos. O pacote de programas está disponível para instituições membros do IRIS Incorporated Research Institutions for Seismology pelo endereço: http://ds.iris.edu/ds/nodes/dmc/software/downloads/sac).

O terceiro procedimento realizado foi o de edição e preenchimento do cabeçalho (header) de cada arquivo (traço sísmico) em formato SAC com as informações pertinentes ao experimento sísmico: hora de origem do tiro em análise, latitude da estação receptora, longitude da estação receptora, elevação da estação receptora, latitude do ponto de tiro em análise, longitude do ponto de tiro em análise e profundidade do ponto de tiro em análise. Essas informações são importantes para o cálculo da distância entre fonte e receptor e para se obter o tempo relativo entre o momento da explosão controlada e o tempo em que o evento é registrado em dada estação receptora ao longo do perfil. Além disso, os traços sísmicos registrados foram cortados em intervalo de tempo de $150 \mathrm{~s}$ a partir da hora de origem de cada explosão controlada.

O quarto procedimento, e mais trabalhoso, consistiu na inspeção visual da qualidade do traço sísmico registrado por cada estação para cada um dos 13 tiros aproveitados. Este procedimento teve como finalidade a remoção de traços "mudos" ou muito ruidosos, provavelmente relacionados a problemas do instrumento ou ao sítio de instalação, e cuja incorporação às seções sísmicas finais não acrescentaria informação relevante. De maneira simplificada: considerando os 13 pontos de tiro, do total de 4.196 traços sísmicos adquiridos, 441 foram removidos, ou seja, cerca de $10,5 \%$ do total.

O último procedimento adotado durante a etapa de processamento visou a geração das seções sísmicas finais para cada ponto de tiro. Foi realizado por meio de sucessão de comandos do pacote de programas SAC aplicados de maneira concatenada por intermédio de um algoritmo (script). Basicamente, para os traços sísmicos de cada tiro, o algoritmo:

a) Lê os arquivos (traços sísmicos) correspondentes a cada ponto de tiro em análise no momento;

b) Aplica operação matemática (Equação 4.1) para cálculo do tempo reduzido a partir de velocidade de redução determinada pelo usuário. Este artifício matemático é utilizado com a finalidade de transformar o eixo de tempo absoluto, $t$, para eixo de tempo reduzido, $t_{R}$, em seções sísmicas. Isto é feito pela subtração de uma velocidade de redução, $v_{R}$, especificada pelo usuário, do tempo de trânsito, $t$, dos traços sísmicos. Este procedimento visa facilitar a identificação de alinhamentos de fases sísmicas que, quando visualizados em tempo absoluto, tendem a estar aglomerados (Figura 4.1); 


$$
t_{R}=t-\frac{x}{v_{R}}
$$

c) Corta o registro de tempo reduzido, $t_{R}$, no intervalo estipulado pelo usuário;

d) Aplica comandos para remover a média e a tendência de cada traço;

e) Aplica filtro do tipo passa-banda no sinal, de acordo com o intervalo estipulado pelo usuário;

f) Ativa o subprocesso SSS (Signal-Stacking Subprocess), interno ao SAC, para a geração da seção sísmica em análise. Neste subprocesso são definidos os parâmetros gráfico-geométricos de cada seção sísmica: orientação, distância em $x$, intervalo do eixo de tempo reduzido, $t_{R}$, e normalização e ganho de amplitude do sinal de cada traço.

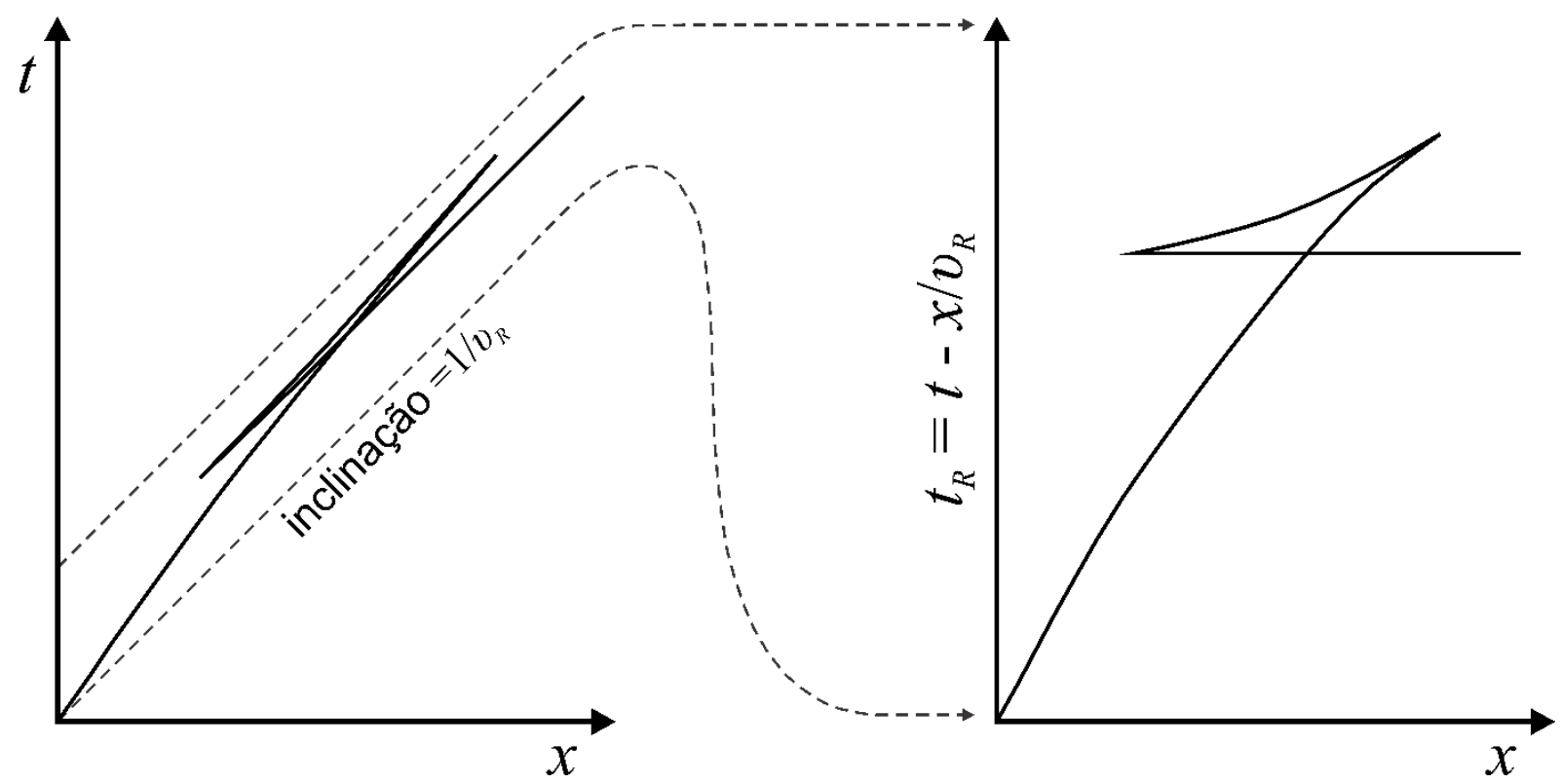

Figura 4.1 Ilustração dos alinhamentos de fases das ondas direta, refratada e refletida antes (esquerda) e após (direita) a aplicação da velocidade de redução, $v_{R}$ (adaptado de Shearer, 2009).

As seções sísmicas de ondas P para os dados do perfil PABBRISE foram geradas com os seguintes parâmetros:

a) Velocidades de redução, $v_{R}$, de 6,5 e $8,0 \mathrm{~km} / \mathrm{s}$. A primeira para ressaltar os alinhamentos de fases mais superficiais, no caso, da bacia e da crosta superior. A 
segunda velocidade de redução foi utilizada para a apresentação, identificação e leitura das feições relevantes de cada seção sísmica;

b) Distância em $x$ do ponto de tiro específico, de acordo com a intensidade do sinal sísmico propagado em cada tiro. Em algumas seções sísmicas (PT-02, 03, 06 e 13) o sinal gerado pelas explosões controladas não se propagou de maneira efetiva, sendo rapidamente atenuado. Nestes casos, as seções sísmicas foram cortadas com a finalidade de remover distâncias $x$ com péssima razão sinal-ruído;

c) Registro de tempo reduzido, $t_{R}$, cortado no intervalo 0-20 s. Este intervalo foi utilizado para eliminar a influência de grandes amplitudes em $t_{R}>20 \mathrm{~s}$ (para $v_{R}=$ $8,0 \mathrm{~km} / \mathrm{s}$ ). O sinal adquirido acima desse tempo reduzido já não seria utilizado e a sua permanência, após a normalização dos dados, possivelmente reduziria a amplitude das fases sísmicas relevantes, presentes entre $0 \leq t_{R} \leq 20 \mathrm{~s}$, para $v_{R}=8,0$ $\mathrm{km} / \mathrm{s}$, o que comprometeria sua correta identificação;

d) Filtro passa-banda de 1-10 Hz. Este intervalo de filtragem foi escolhido por inspeção visual qualitativa e teve a finalidade de isolar o conteúdo de frequência predominante da explosão controlada dos ruídos externos como, por exemplo, boa parte da frequência de vibração natural da Terra e atividades antrópicas.

e) O ganho do sinal também foi aplicado por inspeção visual qualitativa e teve a finalidade de ressaltar a amplitude das fases sísmicas de interesse. Foram utilizados diversos valores de ganho para cada seção e em diferentes momentos.

Com as seções sísmicas finais estabelecidas (Figuras 4.2 e 4.3), a etapa de identificação e leitura dos alinhamentos de fases sísmicas, bem como a modelagem direta, tiveram início. 

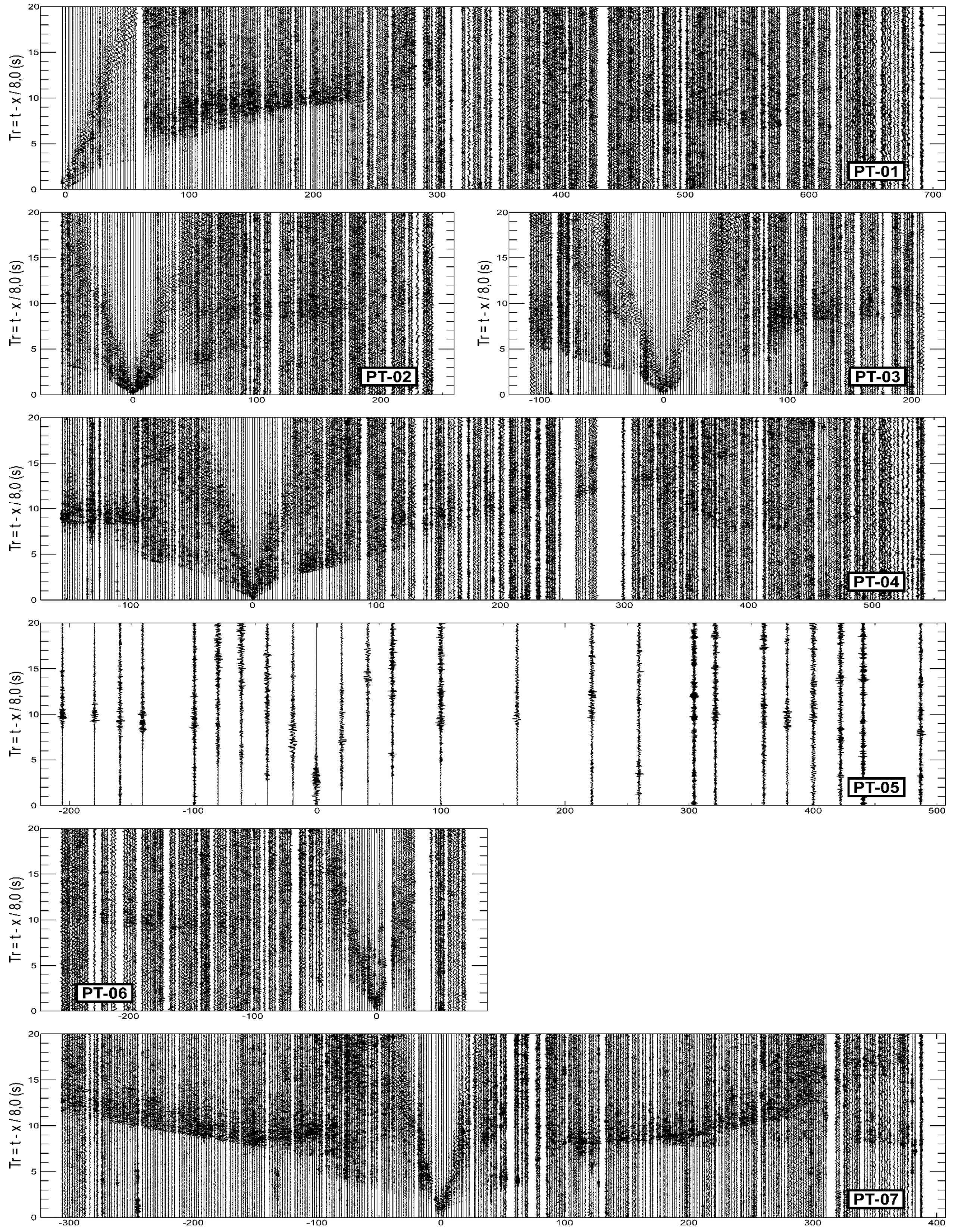

Distância do ponto de tiro $(\mathrm{km})$

Figura 4.2 Seções sísmicas finais dos componentes verticais para ondas P dos pontos de tiro PT-01-07 geradas após todos os procedimentos de processamento. As seções sísmicas são traço-normalizadas, filtradas na banda passante $1-10 \mathrm{~Hz}$ e red
PT-05 possui apenas os registros (traços) das estações triaxiais. 

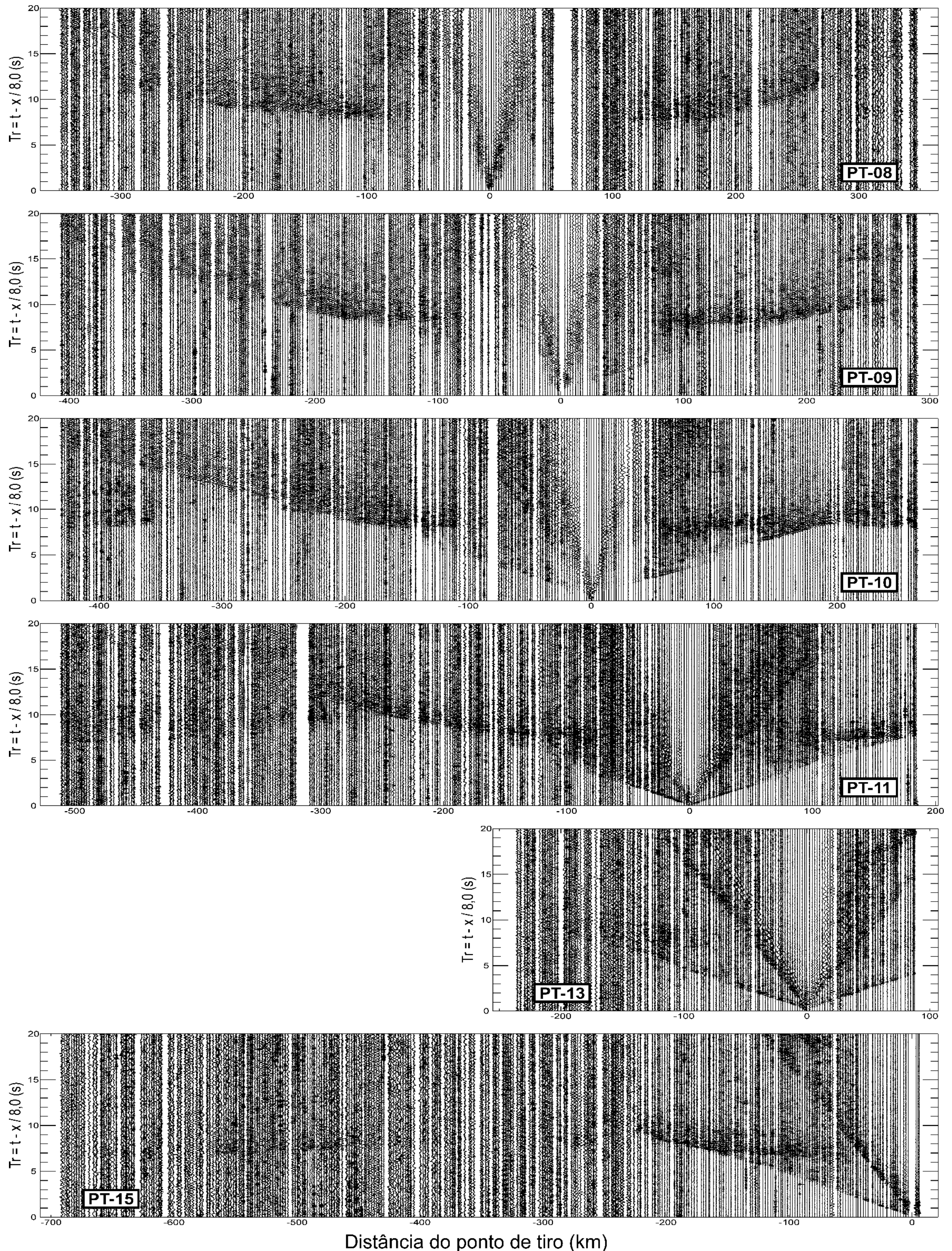

Figura 4.3 Seções sísmicas finais dos componentes verticais para ondas P dos pontos de tiro PT-08-11, 13 e 15, geradas após todos os procedimentos de processamento. As seções sísmicas são traço-normalizadas, filtradas na banda passante $1-10 \mathrm{~Hz}$ e reduzidas com velocidade de redução, $v_{R}$, de $8,0 \mathrm{~km} / \mathrm{s}$. Os traços “mudos" ou muito ruidosos foram removidos. 


\section{CAPÍTULO 5 - ANÁLISE DAS SEÇÕES SÍSMICAS E MODELAGEM DIRETA}

\subsection{Identificação e leitura dos alinhamentos de fases sísmicas}

A identificação de alinhamentos de fases sísmicas é procedimento fundamental no estágio de análise de dados sísmicos de refração/reflexão de ângulo amplo. O modelo sísmico desenvolvido a partir da análise dos dados de tempo de trânsito só é tão bom quanto as leituras em que se baseia (Zelt, 1999). Em outras palavras, erros significativos podem ser introduzidos em um modelo, se os alinhamentos de fases sísmicas forem identificados incorretamente, em consequência do que, cuidados devem ser tomados na identificação e leitura das fases sísmicas.

Como normalmente é em experimentos sísmicos de escala crustal, os principais alinhamentos de fases sísmicas identificados nas seções sísmicas do perfil PABBRISE foram (Figura 5.1):

a) Psed (P "sedimentar"): corresponde a ondas diretas ou refrações incipientes na bacia sedimentar e evidencia parâmetros sísmicos da bacia e de seus derrames basálticos;

b) $P g$ (P "granítica"): corresponde a ondas refratadas no embasamento da bacia e na crosta superior, e evidencia parâmetros sísmicos e de estruturação do embasamento da bacia e da crosta superior;

c) PiP (P "intermediária” $\mathrm{P})$ : corresponde a ondas refletidas por descontinuidade mesocrustal expressiva, e evidencia parâmetros sísmicos e de estruturação da base da crosta superior;

d) $P i$ (P “intermediária”): corresponde a ondas refratadas por descontinuidade mesocrustal expressiva, e evidencia parâmetros sísmicos e de estruturação principalmente do topo da crosta inferior;

e) $\operatorname{PmP}(\mathrm{P}$ “moho” $\mathrm{P})$ : corresponde a ondas refletidas provenientes do limite sísmico crosta-manto, ou seja, da descontinuidade de Mohorovičić, e evidencia parâmetros sísmicos e de estruturação da base da crosta inferior;

f) Pn (P "normal"): corresponde a ondas refratadas pelo manto superior sob a Moho, e evidencia parâmetros sísmicos e de estruturação do topo do manto superior. 

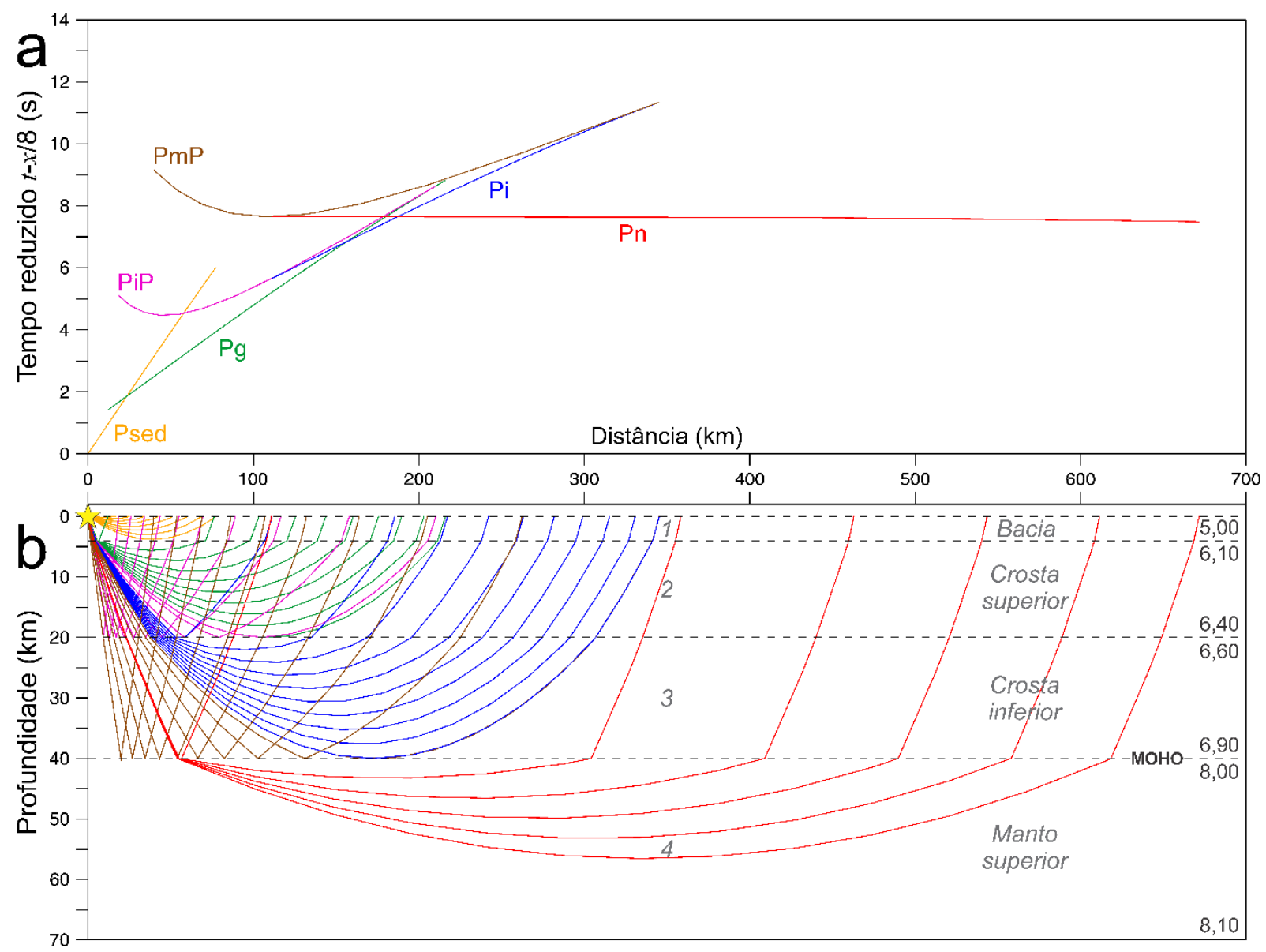

Figura 5.1 Representação esquemático-teórica de curvas distância-tempo (alinhamentos de fases sísmicas) Psed, Pg, PiP, Pi, PmP, Pn geradas pelo RAYINVR (a) por meio do método de traçado de raios em um modelo crustal hipotético (b), com camadas (1-3) e meio-espaço (4) isotrópicos e plano-paralelos. Uma velocidade de redução de $8,0 \mathrm{~km} / \mathrm{s}$ foi aplicada para as curvas tempo-distância em a). Os números na lateral direita de b) representam velocidades hipotéticas (em km/s) para ondas $\mathrm{P}$ nas respectivas interfaces. A estrela amarela em b) representa um ponto de tiro hipotético e, consequentemente, o ponto $(0,0) \mathrm{em} \mathbf{a})$.

O processo de leitura de alinhamentos de fases se deu por intermédio do programa de edição de imagens de código aberto GIMP (GNU Image Manipulation Program, documentação em: http://www.gimp.org). As seções sísmicas geradas para cada ponto de tiro foram sistematicamente importadas para o programa e criados vetores específicos para cada um de seus alinhamentos de fases. Além disso, vários modos de exibição do editor de imagens, como sobreposições (overlays) com ganhos de sinal distintos e amplitudes de reflexões realçadas foram gerados e empregados para auxiliar na identificação e marcação das fases sísmicas.

O procedimento adotado consistiu na identificação e leitura das primeiras chegadas dos alinhamentos das fases Psed, Pg, Pn e, em algumas ocasiões, da Pi e, posteriormente, das reflexões PiP e PmP (quadros $a$ e $b$, figuras 5.2 - 5.14). Estas primeiras leituras foram utilizadas no esboço de modelo sísmico preliminar que auxiliou no aprimoramento das leituras já 
realizadas e também na identificação e leitura de novos alinhamentos de fases. Deste modo, foram realizadas inúmeras iterações deste procedimento de identificação e leitura, e mais fases sísmicas foram incorporadas à medida que se seguiu, tantas vezes quanto foram necessárias, como sugerido por Zelt (1999).

Os vetores dos alinhamentos de fases lidos foram convertidos em banco de dados do programa RAYINVR por algoritmo específico. Este banco de dados ( $t x . i n)$ é do tipo "distânciatempo absoluto" $(x, t)$ e possui quatro colunas. A primeira define a distância $x(\mathrm{em} \mathrm{km})$ de cada fase identificada em relação ao $\mathrm{km}$ zero do modelo. A segunda coluna incorpora todos os tempos absolutos $t$ (em s) de chegada de cada fase identificada. A terceira define a incerteza associada à leitura do tempo de chegada de cada fase. A última coluna identifica cada fase com um número específico (1-5).

Para este trabalho, as incertezas nas leituras das fases foram visualmente atribuídas de maneira qualitativa e generalizada, de acordo com inspeção visual da razão sinal-ruído dos traços. O valor utilizado foi de $100 \mathrm{~ms}$ para todas as fases identificadas e equivale ao diâmetro dos círculos vermelhos (leituras) apresentados em cada seção sísmica interpretada (quadros $b$ e $c$, figuras 5.2-5.14). Esta incerteza foi utilizada por levar em consideração que a razão sinalruído do experimento é, em geral, satisfatória, mesmo para a Bacia do Paraná, caracterizada pela presença de rochas sedimentares intercaladas com derrames, soleiras e diques máficos da grande província ígnea (LIP) do Paraná-Etendeka. Este tipo de ambiente geotectônico influencia negativamente na razão sinal-ruído de experimentos sísmicos (Zalán et al., 1990). De maneira geral, o valor de incerteza atribuído está dentro do intervalo definido em trabalhos em que inspeções e testes quantitativos foram realizados (Rumpfhuber, 2008; Starostenko et al., 2013; Evain et al., 2015).

No total, foram lidos 2.816 tempos de chegada nas treze seções sísmicas, sendo: 144 para Psed, 815 para Pg, 51 para PiP, 519 para Pi, 981 para PmP e 306 para Pn. A partir deste banco de dados foi realizada a modelagem direta do tempo de trânsito das ondas P, apresentada nas figuras 5.2-5.14 a seguir. 

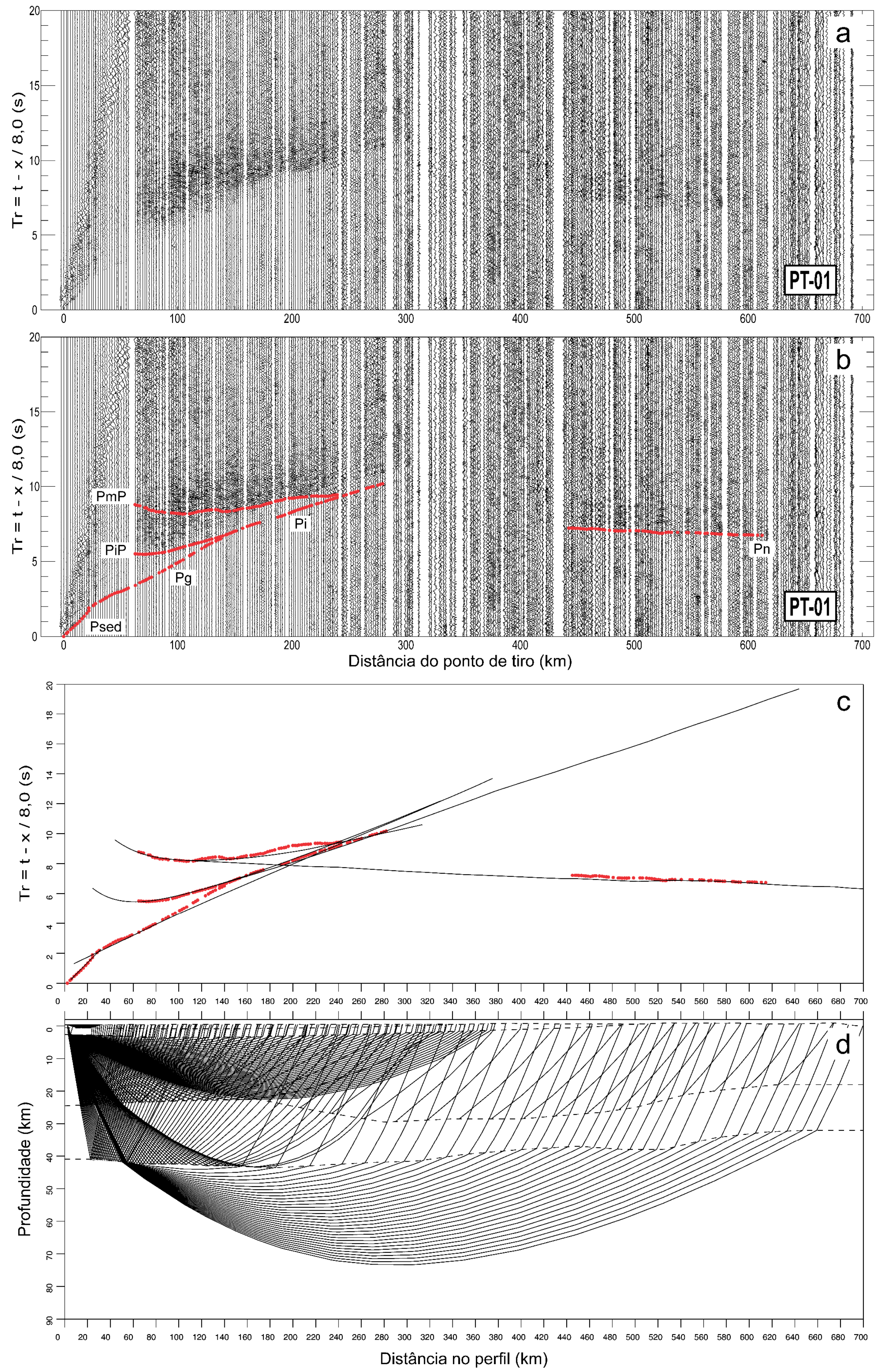

Figura 5.2 Seção sísmica traço-normalizada dos componentes verticais para ondas P do ponto de tiro PT-01 e os ajustes obtidos na modelagem. A seção sísmica foi filtrada na banda passante 1-10 Hz. A velocidade de redução é de $8,0 \mathrm{~km} / \mathrm{s}$. a) Seção sísmica processada; b) Seção sísmica com as leituras (círculos vermelhos) utilizadas para a modelagem; c) Diagrama dos ajustes obtidos para os tempos de trânsito teóricos (linhas pretas) calculados pelo método do traçado de raios; d) Diagrama de raios teóricos associados ao modelo obtido. 

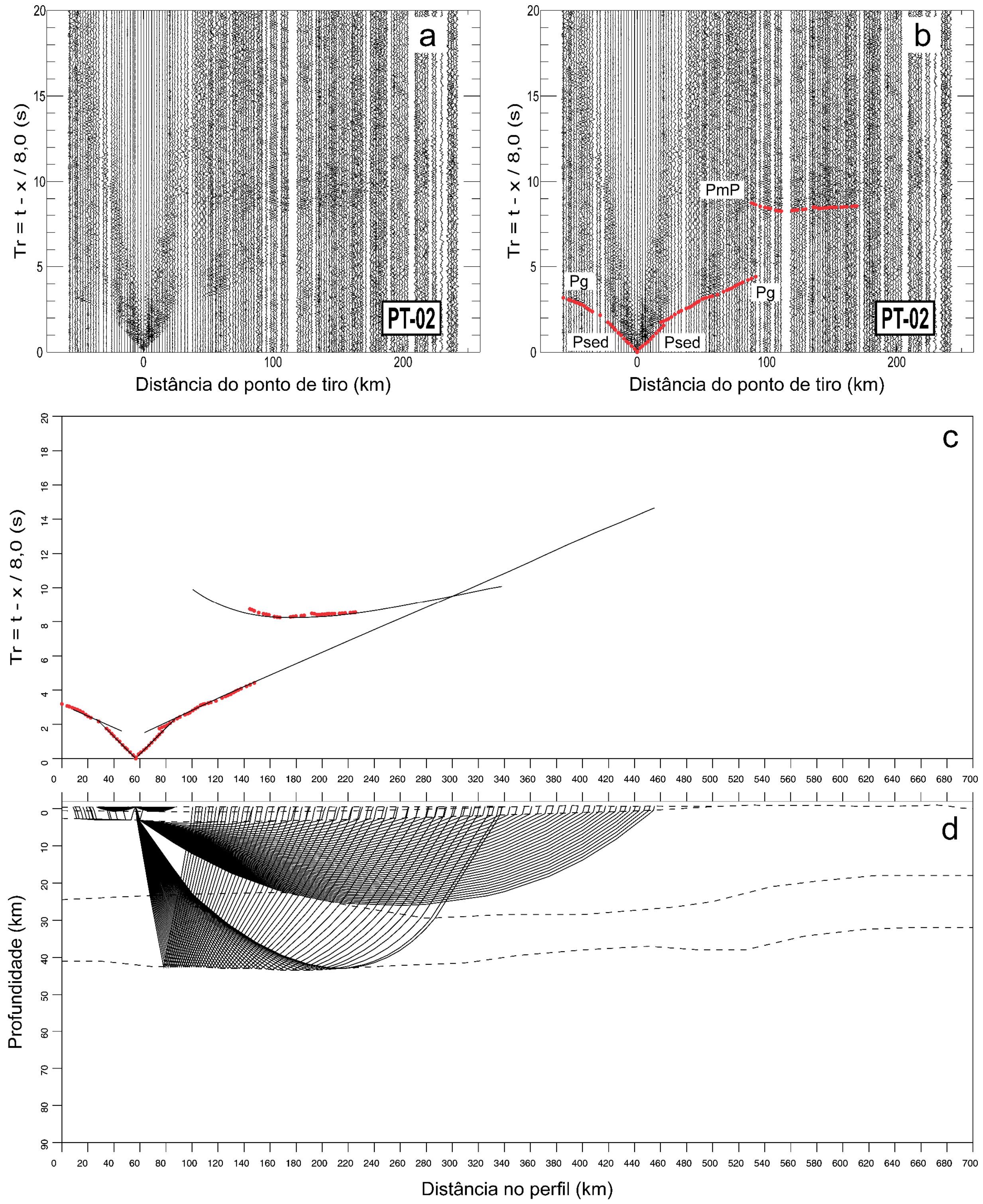

Figura 5.3 Seção sísmica traço-normalizada dos componentes verticais para ondas P do ponto de tiro PT-02 e os ajustes obtidos na modelagem. A seção sísmica foi filtrada na banda passante 1-10 Hz. A velocidade de redução é de $8,0 \mathrm{~km} / \mathrm{s}$. a) Seção sísmica processada; b) Seção sísmica com as leituras (círculos vermelhos) utilizadas para a modelagem; c) Diagrama dos ajustes obtidos para os tempos de trânsito teóricos (linhas pretas) calculados pelo método do traçado de raios; d) Diagrama de raios teóricos associados ao modelo obtido. 

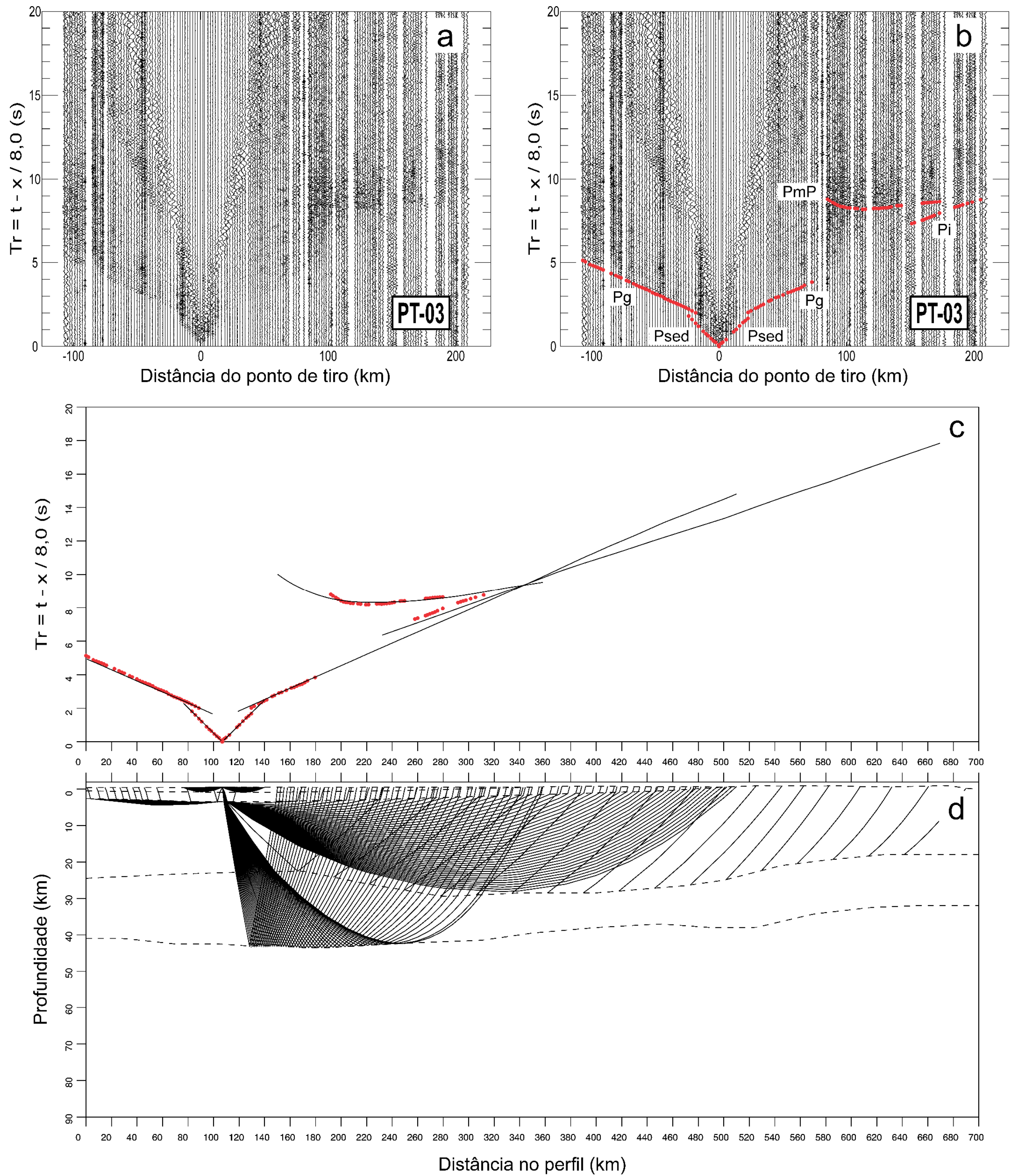

Figura 5.4 Seção sísmica traço-normalizada dos componentes verticais para ondas $\mathrm{P}$ do ponto de tiro PT-03 e os ajustes obtidos na modelagem. A seção sísmica foi filtrada na banda passante 1-10 Hz. A velocidade de redução é de $8,0 \mathrm{~km} / \mathrm{s}$. a) Seção sísmica processada; b) Seção sísmica com as leituras (círculos vermelhos) utilizadas para a modelagem; c) Diagrama dos ajustes obtidos para os tempos de trânsito teóricos (linhas pretas) calculados pelo método do traçado de raios; d) Diagrama de raios teóricos associados ao modelo obtido. 

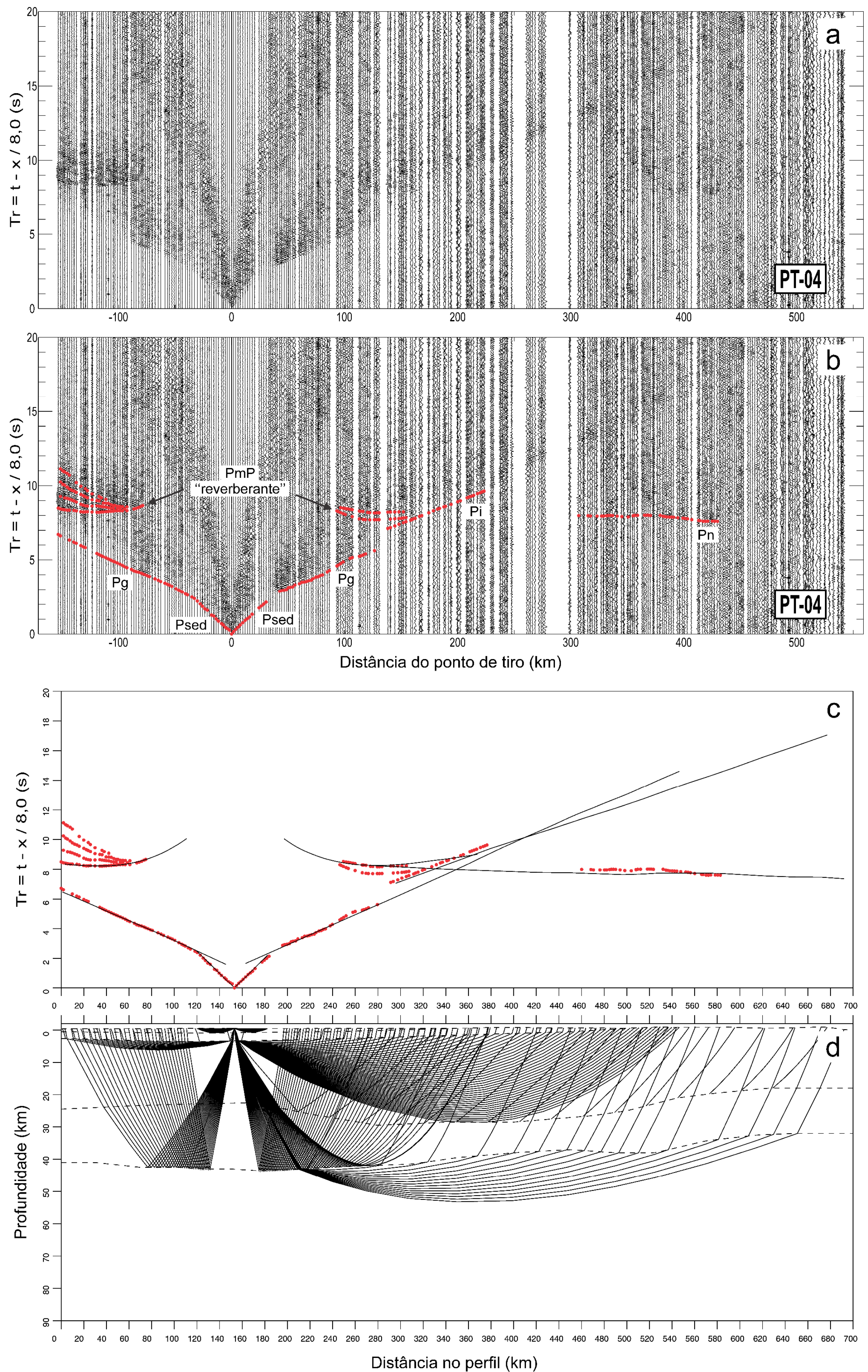

Figura 5.5 Seção sísmica traço-normalizada dos componentes verticais para ondas P do ponto de tiro PT-04 e os ajustes obtidos na modelagem. A seção sísmica foi filtrada na banda passante 1-10 Hz. A velocidade de redução é de $8,0 \mathrm{~km} / \mathrm{s}$. a) Seção sísmica processada; b) Seção sísmica com as leituras (círculos vermelhos) utilizadas para a modelagem; c) Diagrama dos ajustes obtidos para os tempos de trânsito teóricos (linhas pretas) calculados pelo método do traçado de raios; d) Diagrama de raios teóricos associados ao modelo obtido. 

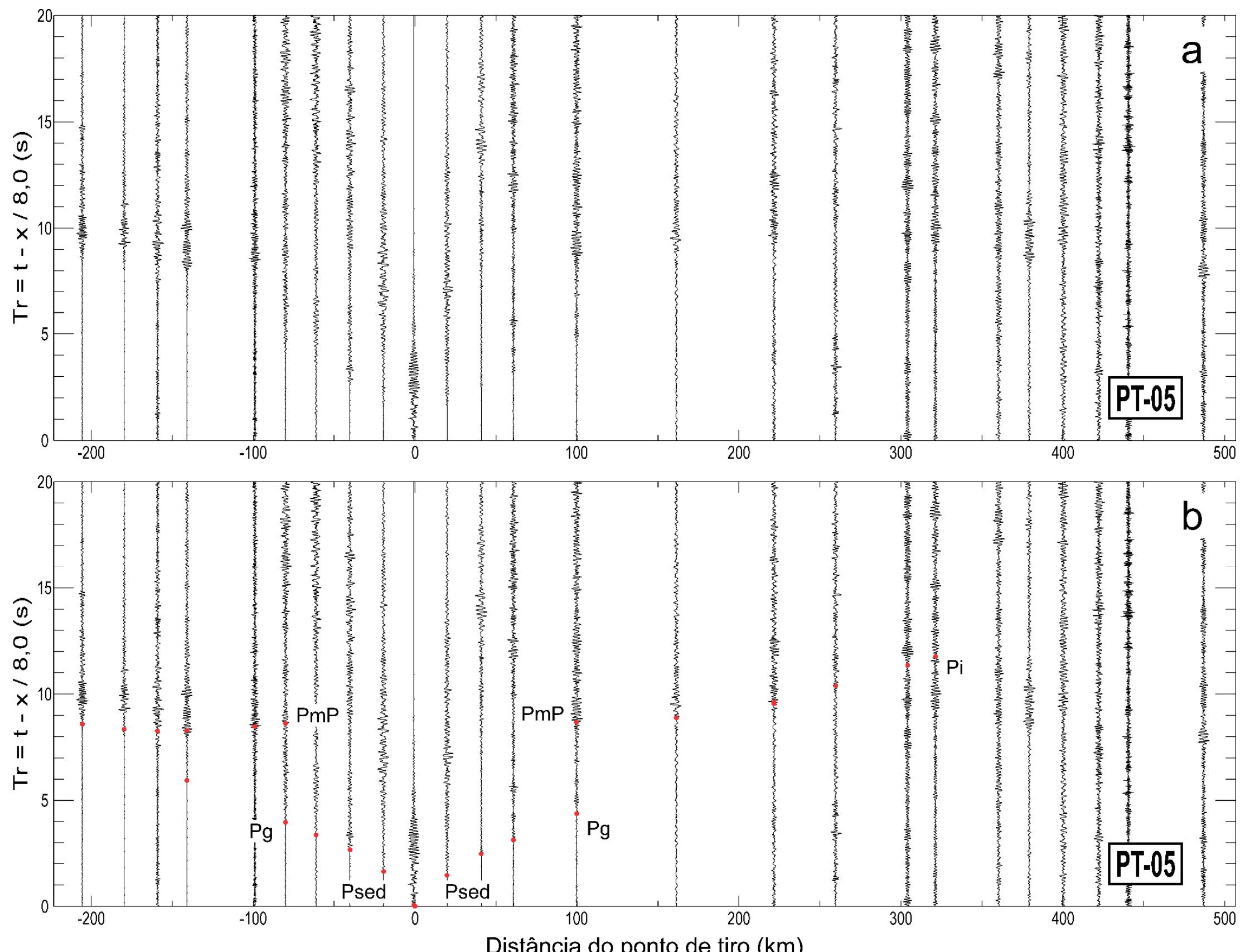

Distância do ponto de tiro $(\mathrm{km})$


Figura 5.6 Seção sísmica traço-normalizada dos componentes verticais para ondas P do ponto de tiro PT-05 e os ajustes obtidos na modelagem. A seção sísmica foi filtrada na banda passante 1-10 Hz. A velocidade de redução é de $8,0 \mathrm{~km} / \mathrm{s}$. a) Seção sísmica processada; b) Seção sísmica com as leituras (círculos vermelhos) utilizadas para a modelagem; c) Diagrama dos ajustes obtidos para os tempos de trânsito teóricos (linhas pretas) calculados pelo método do traçado de raios; d) Diagrama de raios teóricos associados ao modelo obtido. 

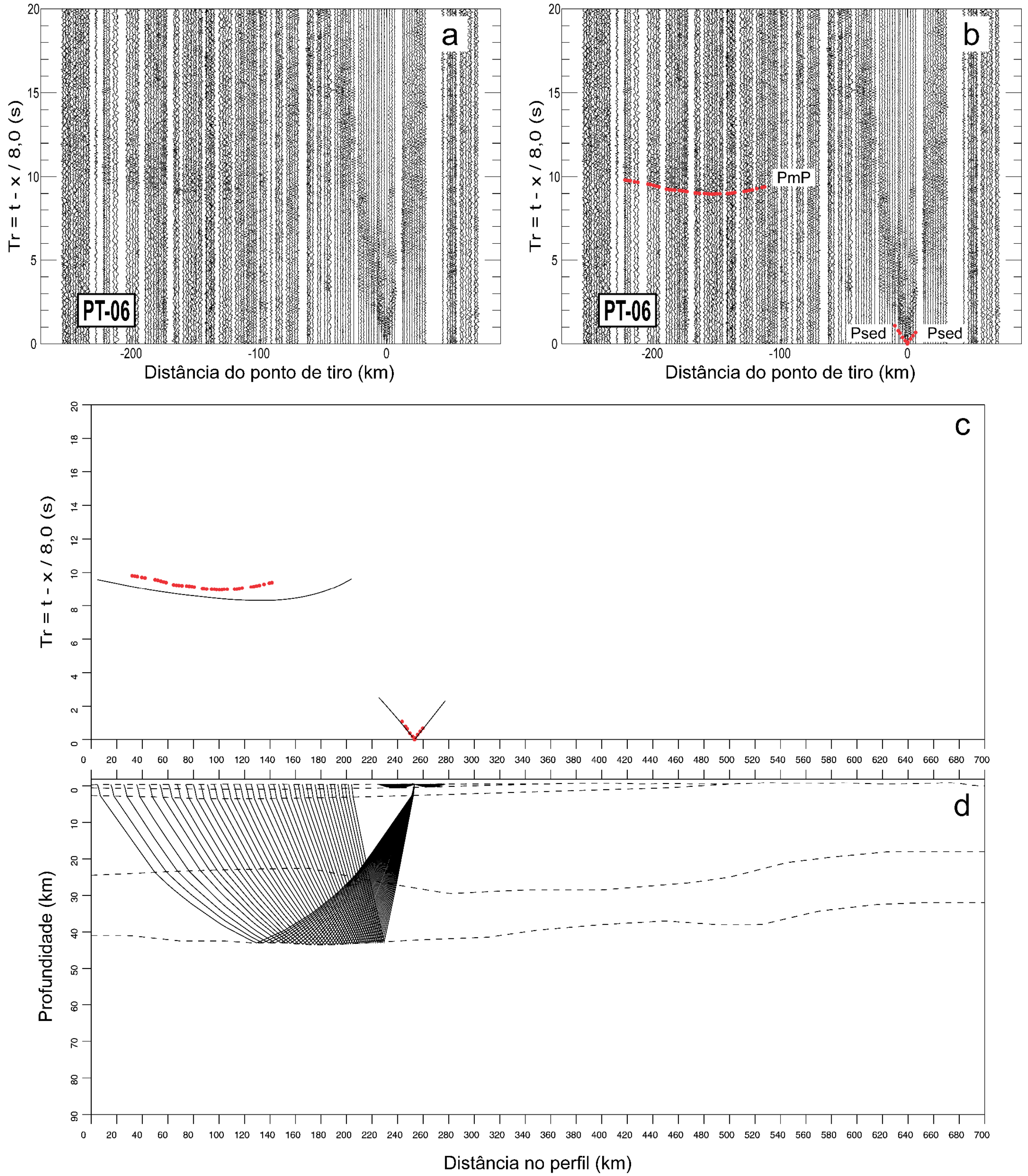

Figura 5.7 Seção sísmica traço-normalizada dos componentes verticais para ondas P do ponto de tiro PT-06 e os ajustes obtidos na modelagem. A seção sísmica foi filtrada na banda passante 1-10 Hz. A velocidade de redução é de $8,0 \mathrm{~km} / \mathrm{s}$. a) Seção sísmica processada; b) Seção sísmica com as leituras (círculos vermelhos) utilizadas para a modelagem; c) Diagrama dos ajustes obtidos para os tempos de trânsito teóricos (linhas pretas) calculados pelo método do traçado de raios; d) Diagrama de raios teóricos associados ao modelo obtido. 

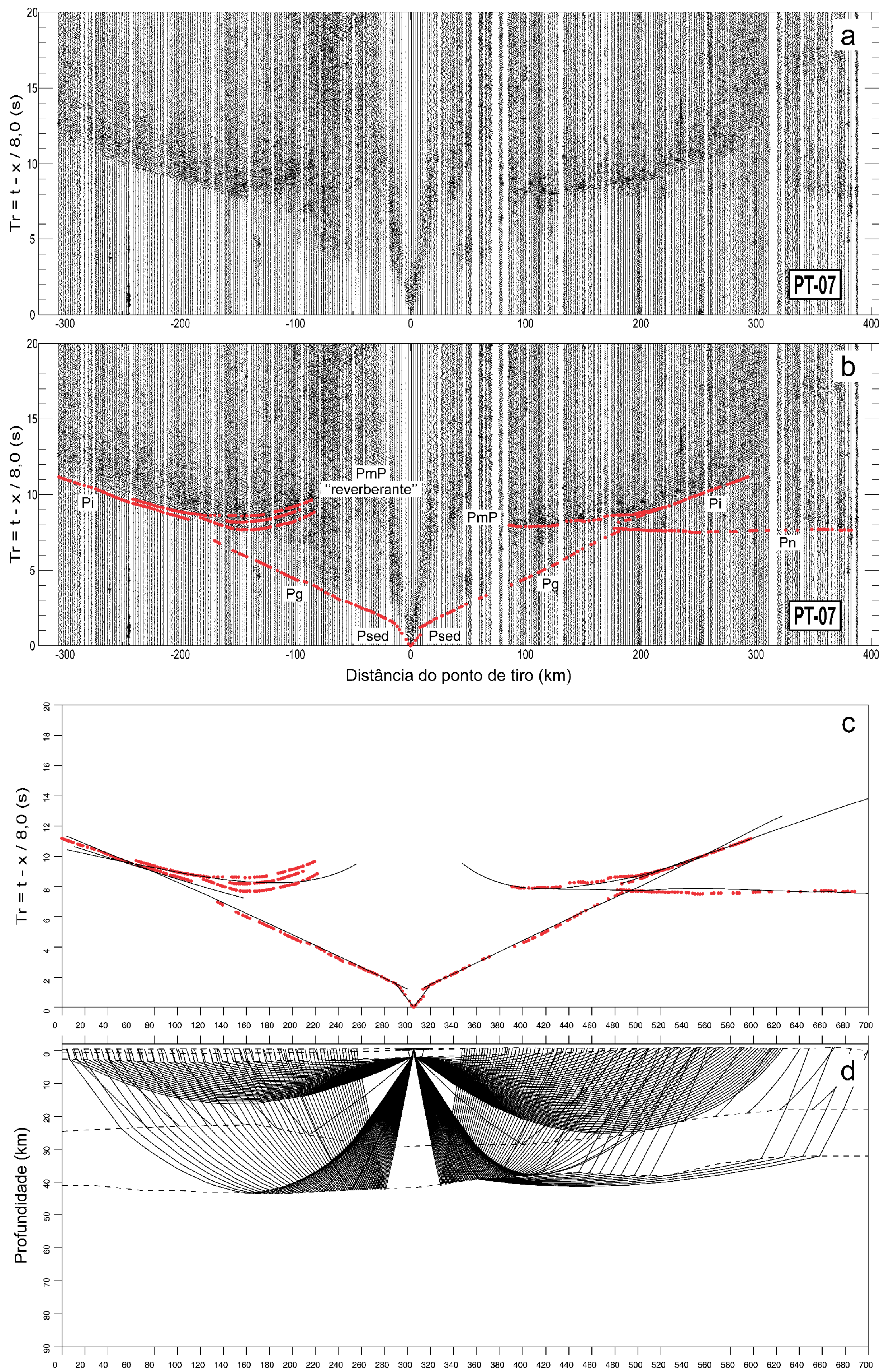

Distância no perfil $(\mathrm{km})$

Figura 5.8 Seção sísmica traço-normalizada dos componentes verticais para ondas P do ponto de tiro PT-07 e os ajustes obtidos na modelagem. A seção sísmica foi filtrada na banda passante 1-10 Hz. A velocidade de redução é de $8,0 \mathrm{~km} / \mathrm{s}$. a) Seção sísmica processada; b) Seção sísmica com as leituras (círculos vermelhos) utilizadas para a modelagem; c) Diagrama dos ajustes obtidos para os tempos de trânsito teóricos (linhas pretas) calculados pelo método do traçado de raios; d) Diagrama de raios teóricos associados ao modelo obtido. 

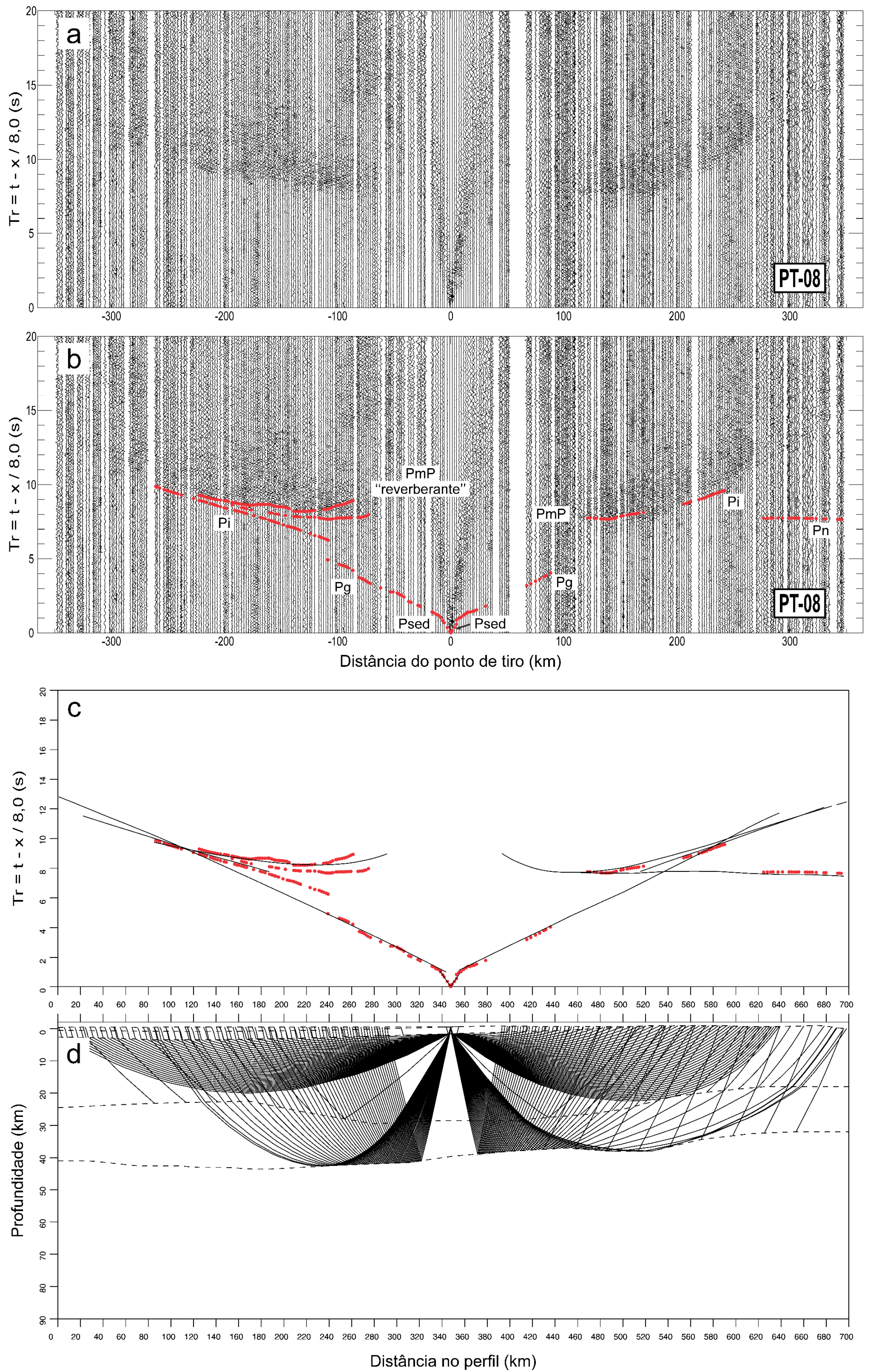

Figura 5.9 Seção sísmica traço-normalizada dos componentes verticais para ondas P do ponto de tiro PT-08 e os ajustes obtidos na modelagem. A seção sísmica foi filtrada na banda passante 1-10 Hz. A velocidade de redução é de $8,0 \mathrm{~km} / \mathrm{s}$. a) Seção sísmica processada; b) Seção sísmica com as leituras (círculos vermelhos) utilizadas para a modelagem; c) Diagrama dos ajustes obtidos para os tempos de trânsito teóricos (linhas pretas) calculados pelo método do traçado de raios; d) Diagrama de raios teóricos associados ao modelo obtido. 

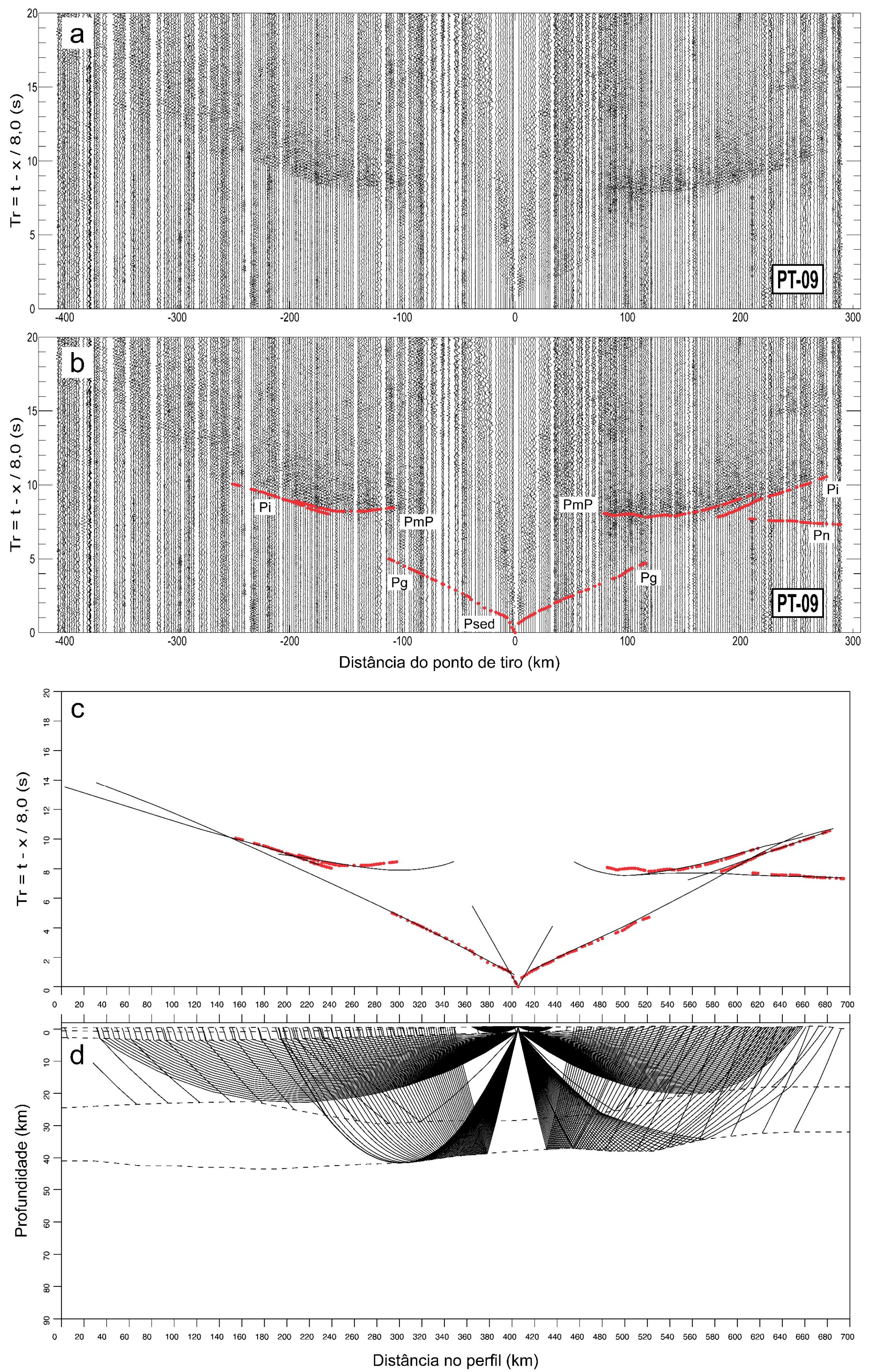

Figura 5.10 Seção sísmica traço-normalizada dos componentes verticais para ondas P do ponto de tiro PT-09 e os ajustes obtidos na modelagem. A seção sísmica foi filtrada na banda passante 1-10 Hz. A velocidade de redução é de $8,0 \mathrm{~km} / \mathrm{s}$. a) Seção sísmica processada; b) Seção sísmica com as leituras (círculos vermelhos) utilizadas para a modelagem; c) Diagrama dos ajustes obtidos para os tempos de trânsito teóricos (linhas pretas) calculados pelo método do traçado de raios; d) Diagrama de raios teóricos associados ao modelo obtido. 

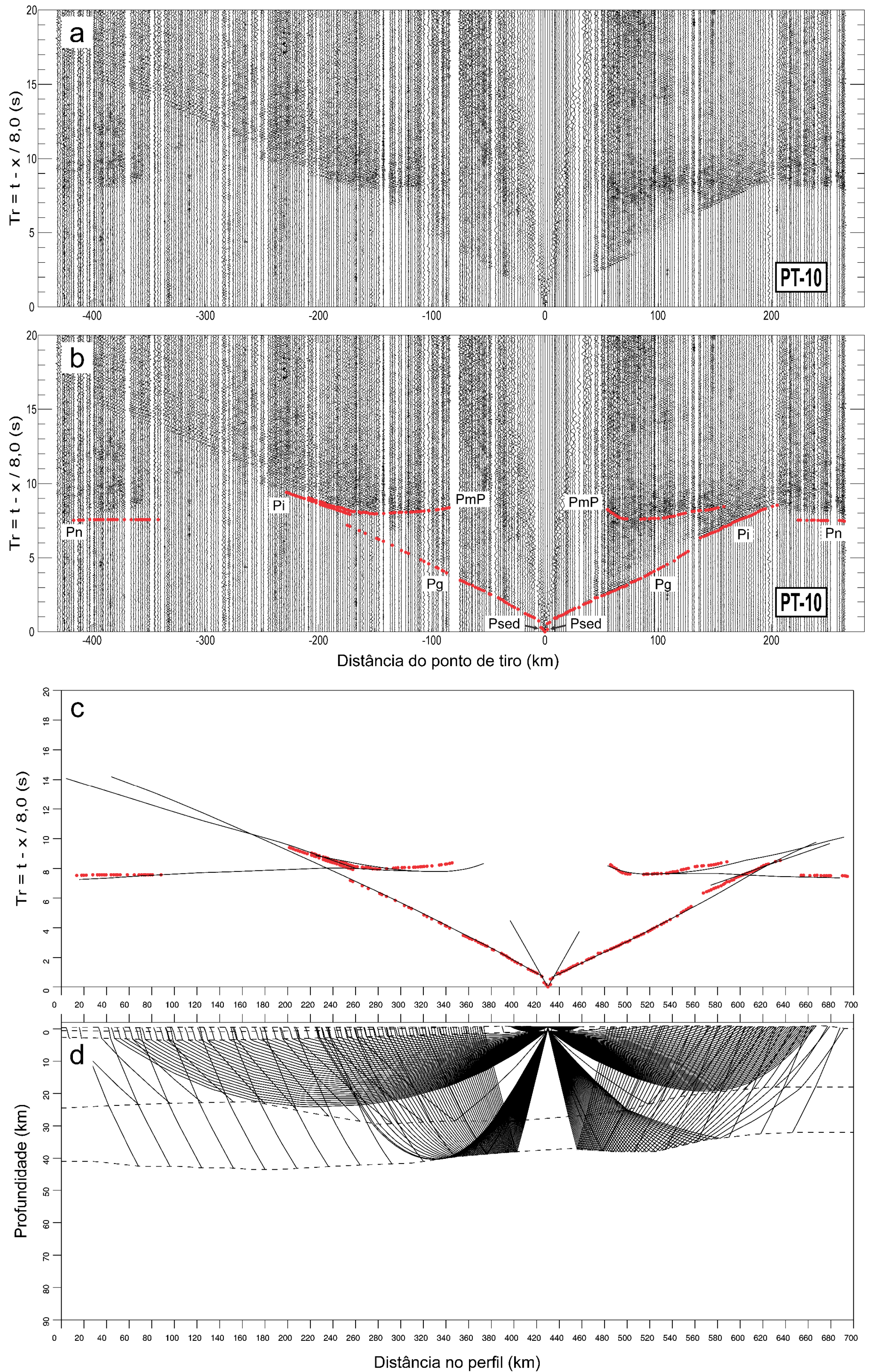

Figura 5.11 Seção sísmica traço-normalizada dos componentes verticais para ondas P do ponto de tiro PT-10 e os ajustes obtidos na modelagem. A seção sísmica foi filtrada na banda passante 1-10 Hz. A velocidade de redução é de $8,0 \mathrm{~km} / \mathrm{s}$. a) Seção sísmica processada; b) Seção sísmica com as leituras (círculos vermelhos) utilizadas para a modelagem; c) Diagrama dos ajustes obtidos para os tempos de trânsito teóricos (linhas pretas) calculados pelo método do traçado de raios; d) Diagrama de raios teóricos associados ao modelo obtido. 

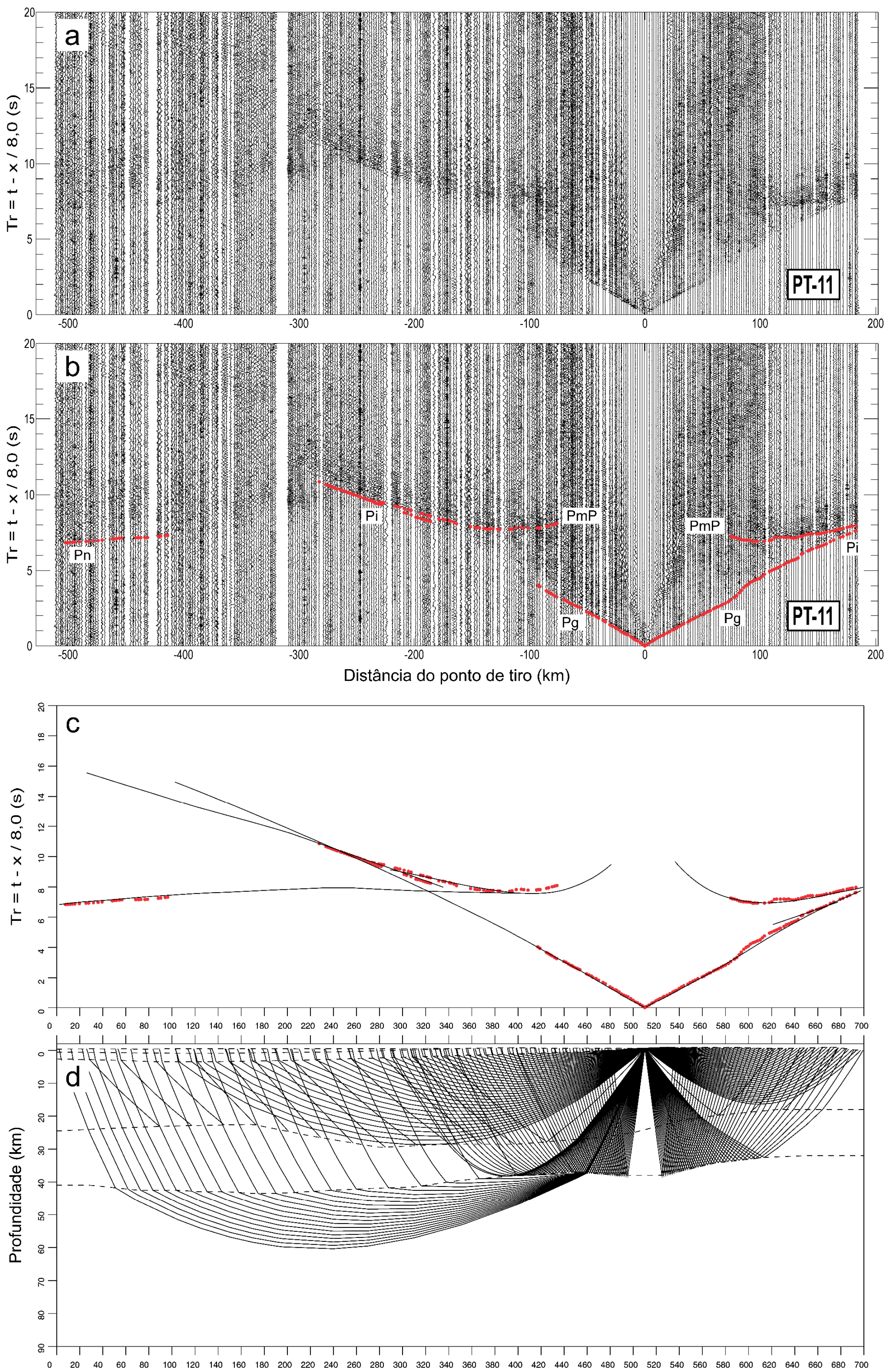

Distância no perfil $(\mathrm{km})$

Figura 5.12 Seção sísmica traço-normalizada dos componentes verticais para ondas P do ponto de tiro PT-11 e os ajustes obtidos na modelagem. A seção sísmica foi filtrada na banda passante 1-10 Hz. A velocidade de redução é de $8,0 \mathrm{~km} / \mathrm{s}$. a) Seção sísmica processada; b) Seção sísmica com as leituras (círculos vermelhos) utilizadas para a modelagem; c) Diagrama dos ajustes obtidos para os tempos de trânsito teóricos (linhas pretas) calculados pelo método do traçado de raios; d) Diagrama de raios teóricos associados ao modelo obtido. 

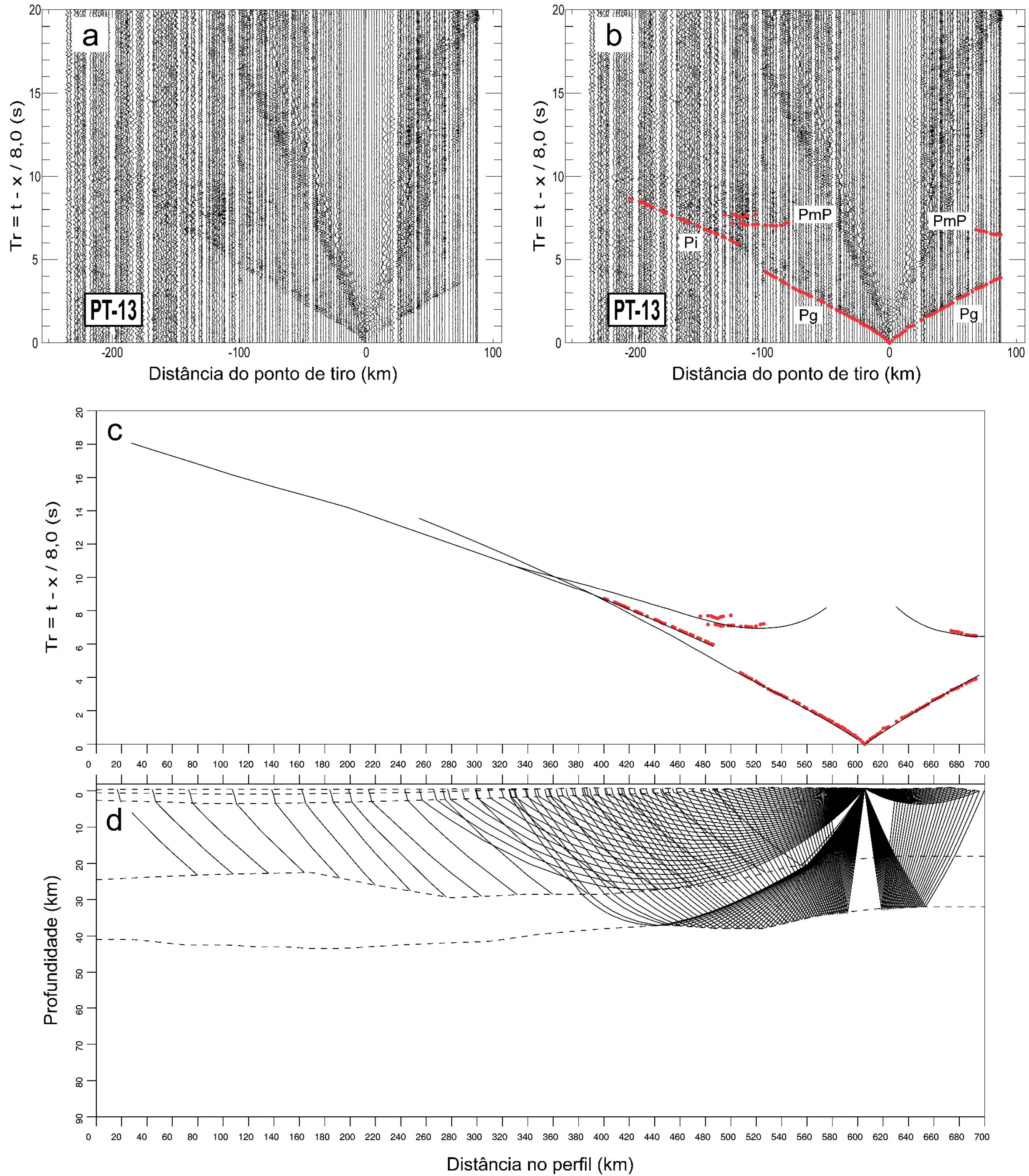

Figura 5.13 Seção sísmica traço-normalizada dos componentes verticais para ondas P do ponto de tiro PT-13 e os ajustes obtidos na modelagem. A seção sísmica foi filtrada na banda passante 1-10 Hz. A velocidade de redução é de $8,0 \mathrm{~km} / \mathrm{s}$. a) Seção sísmica processada; b) Seção sísmica com as leituras (círculos vermelhos) utilizadas para a modelagem; c) Diagrama dos ajustes obtidos para os tempos de trânsito teóricos (linhas pretas) calculados pelo método do traçado de raios; d) Diagrama de raios teóricos associados ao modelo obtido. 

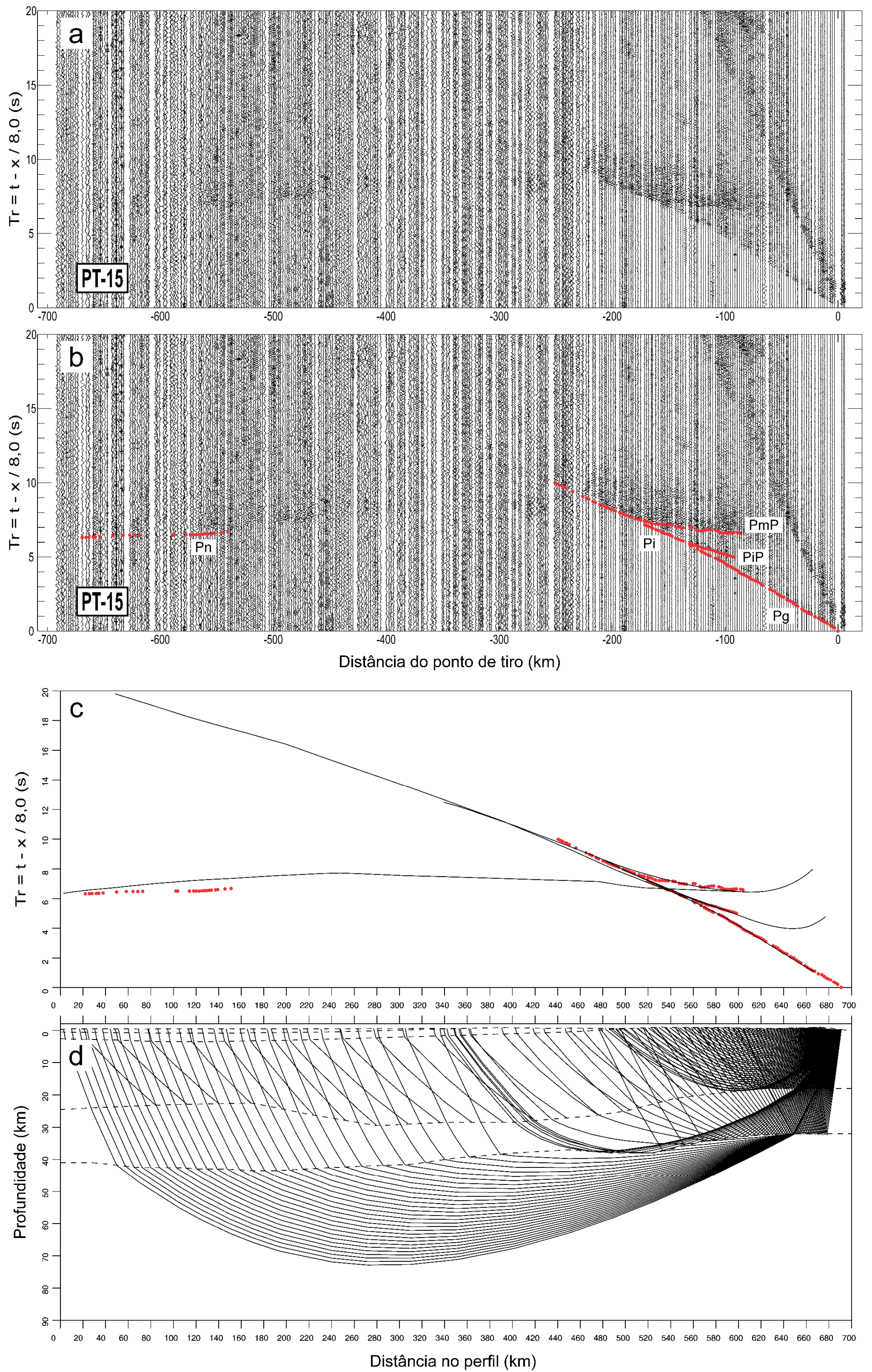

Figura 5.14 Seção sísmica traço-normalizada dos componentes verticais para ondas P do ponto de tiro PT-15 e os ajustes obtidos na modelagem. A seção sísmica foi filtrada na banda passante 1-10 Hz. A velocidade de redução é de $8,0 \mathrm{~km} / \mathrm{s}$. a) Seção sísmica processada; b) Seção sísmica com as leituras (círculos vermelhos) utilizadas para a modelagem; c) Diagrama dos ajustes obtidos para os tempos de trânsito teóricos (linhas pretas) calculados pelo método do traçado de raios; d) Diagrama de raios teóricos associados ao modelo obtido. 


\subsection{Modelagem direta e ajustes obtidos}

Um modelo preliminar foi elaborado levando em consideração os limites geológicos em superfície, como o afinamento ("pinch-out”) progressivo dos derrames basálticos e das rochas sedimentares da Bacia do Paraná para sudeste. A topografia foi incorporada ao longo do modelo por meio de nós de elevação, um a cada $10 \mathrm{~km}$, extraídos do modelo de relevo ETOPO1 (Amante \& Eakins, 2009). Por ter sido incorporada ao modelo, não foi necessário realizar procedimento de compensação topográfica na modelagem do tempo de trânsito dos raios sísmicos. As variações de amplitude das fases sísmicas foram consideradas de forma qualitativa, principalmente na definição dos pontos críticos dos alinhamentos PmP/Pn e na interpretação de algumas estruturas localizadas no modelo obtido.

Após a construção do modelo inicial, foi adotada a estratégia de modelagem direta pela abordagem de "remoção de camada" (layer-stripping approach). Esta estratégia é recomendada por Zelt \& Smith (1992) e Zelt (1999) e consiste em uma aproximação do tipo "através e para baixo" (across-and-down), em que as camadas superficiais foram modeladas primeiramente. Quando as curvas teóricas (curvas pretas, quadro $c$, figuras 5.2 - 5.14) se igualam satisfatoriamente às leituras dos tempos de trânsito dos respectivos alinhamentos de fases (círculos vermelhos, quadro c, figuras 5.2 - 5.14), fases mais profundas passam a ser modeladas, enquanto que a camada superior, já modelada, permanece inalterada. Em outras palavras, as fases Psed foram modeladas primeiramente. Após o ajuste destas fases ser considerado satisfatório, as leituras das fases $\mathrm{Pg}$, que representam a crosta superior, passam a ser modeladas da mesma maneira, e assim por diante, até as camadas mais profundas, representadas pelos alinhamentos de fases PmP e Pn.

A incorporação das isópacas dos derrames basálticos (Zalán et al., 1990) e da profundidade do embasamento sob a Bacia do Paraná (Bizzi et al., 2003) possibilitou que a inversão de velocidade sísmica existente fosse considerada e modelada. A inversão de velocidade é um fator complicador para o método de refração sísmica e, na Bacia do Paraná, decorre do fato de os derrames basálticos, de velocidades maiores, estarem sobrepostos as rochas sedimentares pré-vulcânicas (Mesozóico/Paleozóico), de velocidades menores. Modelo magnetotelúrico de alta resolução corrobora a geometria utilizada para a bacia (Minei, 2015). $\mathrm{Na}$ ausência deste tipo de controle, a profundidade do pacote bacinal na região com os derrames basálticos mais espessos seria superestimada em cerca de $35 \%$, situação que introduziria erros na definição do limite com a crosta superior do modelo final. 
Os ajustes obtidos para os alinhamentos de fase Psed, que ocorrem exclusivamente na Bacia do Paraná (PT-01 a PT-10), foram excelentes (Figura 5.15). Os ajustes demonstram variação lateral na inclinação (coeficiente angular) e no comprimento das curvas de alinhamentos de fases. Isto, por sua vez, indica variação lateral na velocidade das ondas $\mathrm{P}$ e na espessura das camadas ao longo da Bacia do Paraná.
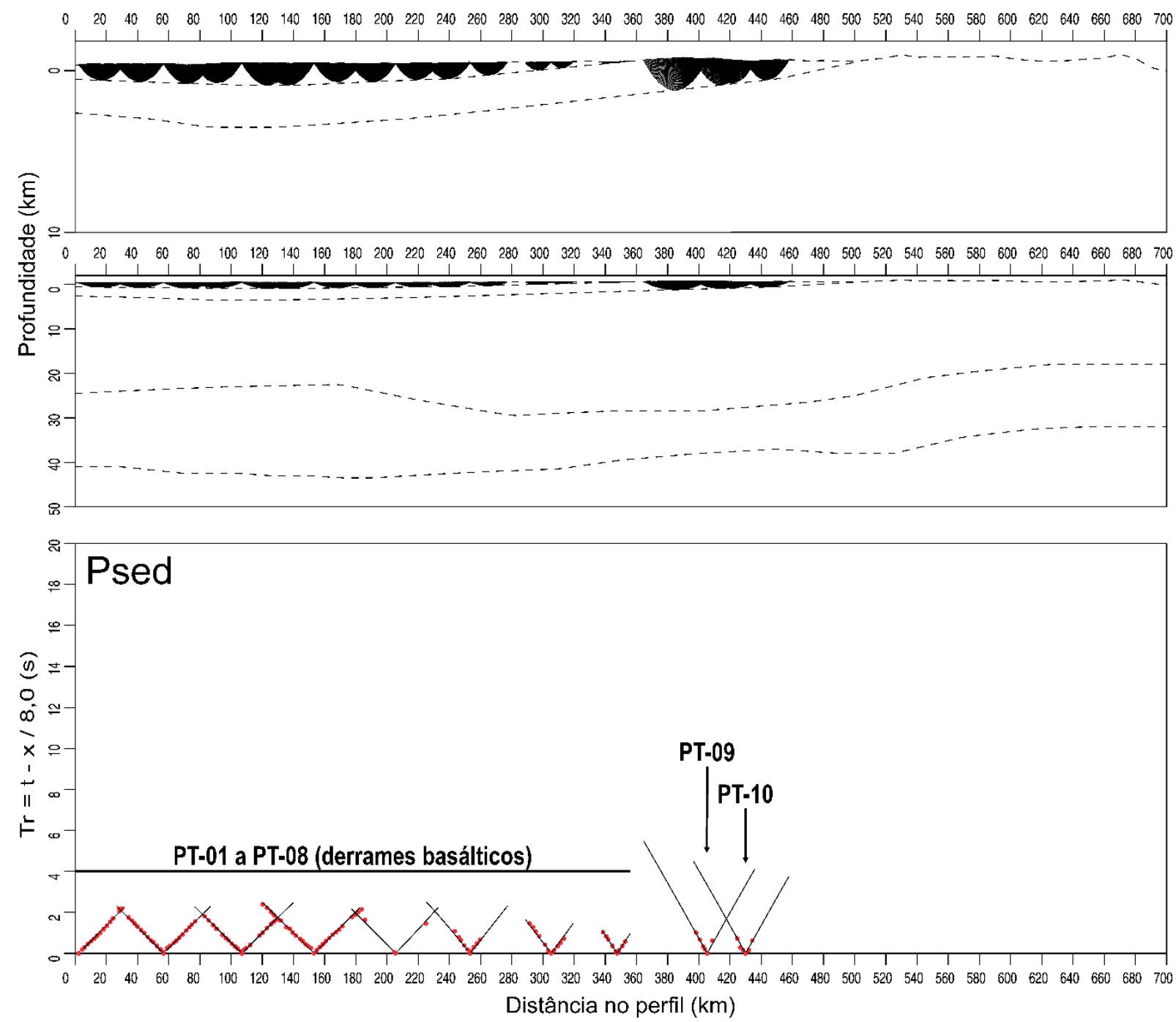

Figura 5.15 Detalhe dos ajustes obtidos para todos os alinhamentos de fase Psed nas camadas da Bacia do Paraná: derrames basálticos e rochas sedimentares pré-vulcânicas. Observar a diferença na inclinação e extensão das curvas lidas. Tais características indicam variação lateral e vertical de propriedades sísmicas internas à bacia.

Os ajustes obtidos para os alinhamentos de fase Pg também foram excelentes (Figura 5.16). Demonstram que, no geral, os gradientes de velocidade vertical e lateral para a crosta superior são suaves e estão em sintonia. A exceção ocorre apenas em porções específicas dos 
pontos de tiro PT-01 e PT-11, onde as leituras sugerem restritas e descontínuas zonas de baixa velocidade sísmica em porções discretas da crosta superior ( $\mathrm{LVZ}$ - low velocity zones na Figura 5.16). Estas zonas não foram incorporadas ao modelo devido à sua descontinuidade lateral $\mathrm{e}$ não observação em outros pontos de tiro, mas podem representar possíveis regiões de maior complexidade estrutural na crosta superior.
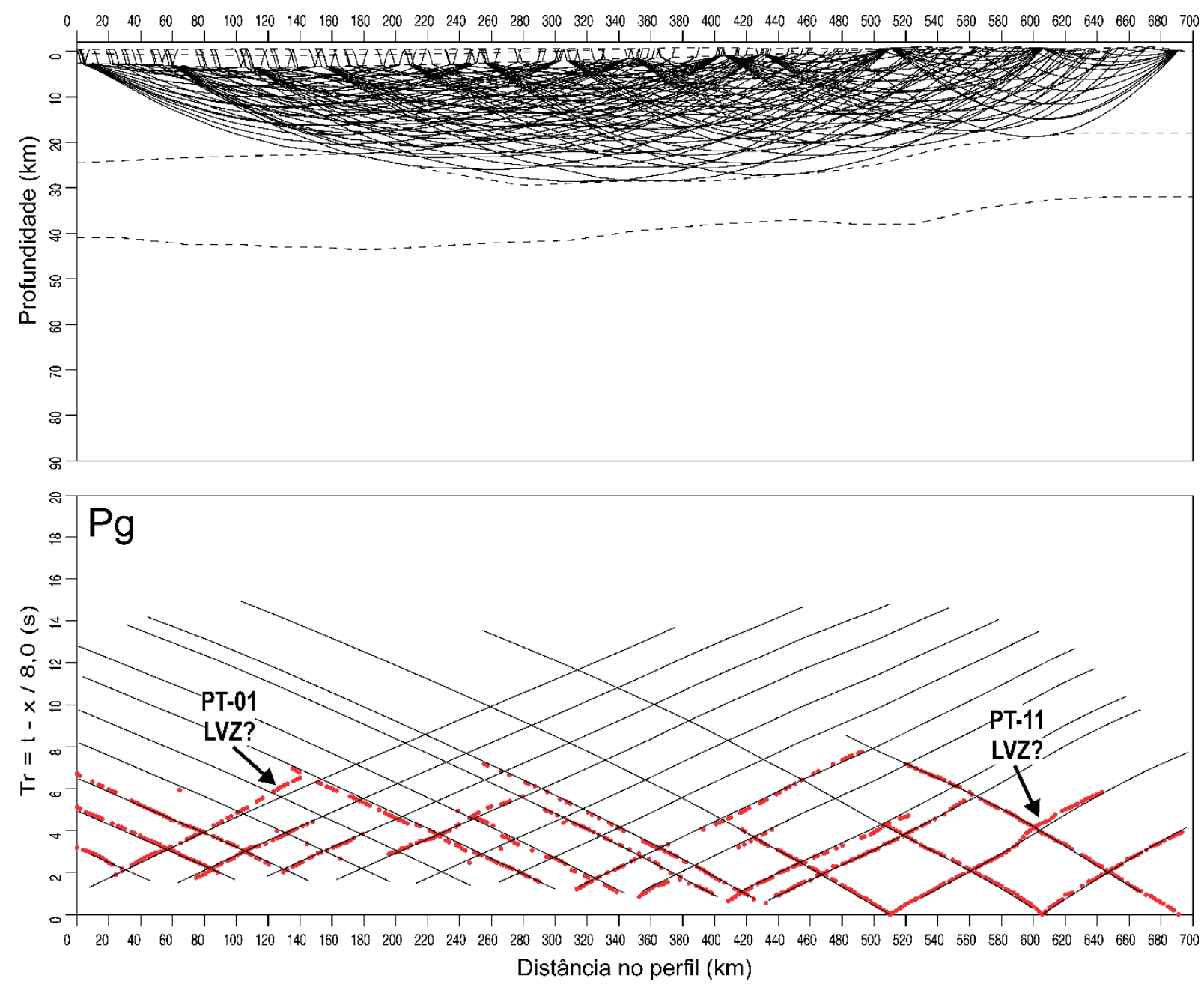

Figura 5.16 Detalhe dos ajustes obtidos para os alinhamentos de fase Pg (crosta superior). LVZ - zonas de baixa velocidade (low velocity zones). Observe que os gradientes laterais e verticais obtidos para a crosta superior são suaves e estão bem ajustados.

Por sua vez, os ajustes obtidos para os alinhamentos de fase Pi podem ser classificados, de maneira qualitativa, como bons a satisfatórios. Não foi possível obter alinhamento de fase Pi para algumas seções sísmicas (e.g. PT-02 e PT-06) devido às baixas razões sinal-ruído observadas nas seções sísmicas destes pontos de tiro. Os ajustes da fase Pi para os pontos de 
tiro PT-03 e PT-04 positivos (para sudeste) e PT-15 negativo (para noroeste) ficaram inferiores ao esperado (ver setas, figura 5.17). No entanto a inclinação das curvas teóricas ficou adequada, demonstrando que os campos de velocidade da crosta superior e do topo da crosta inferior estão bem modelados. A ausência de ajuste fino estaria então relacionada à precisão na inclinação e no posicionamento lateral de porções das rampas definidas pela descontinuidade mesocrustal.
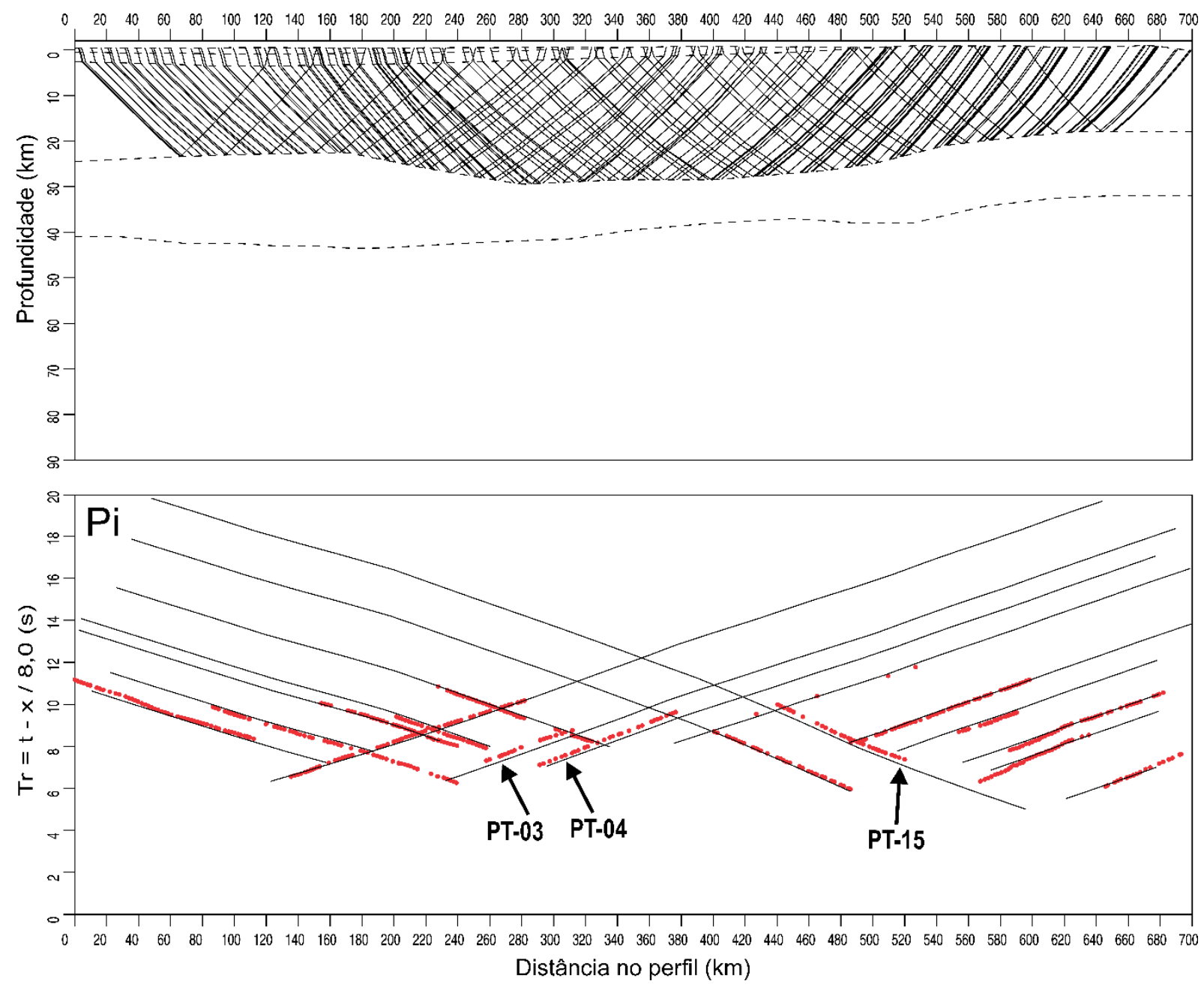

Figura 5.17 Detalhe dos ajustes obtidos para os alinhamentos de fase Pi lidos (topo da crosta inferior). De maneira geral, os ajustes para esta fase ficaram bons a satisfatórios. As setas indicam os pontos de tiro cujo ajuste para a curva ficou aquém do esperado (além da incerteza associada).

De maneira semelhante, os ajustes obtidos para os alinhamentos de fases mais profundos, PmP e Pn, também podem ser qualificados como bons (Figuras 5.2 a 5.14). Os alinhamentos de fase PmP são mais complexos e heterogêneos, sendo diferentes e com características sísmicas próprias para cada região do perfil. Fases PmP classificadas como 
"reverberantes" são observadas nos pontos de tiro PT-04, PT-07 e PT-08 e sugerem limite crosta-manto estruturado, e não simplesmente como uma descontinuidade de primeira ordem direta. Os alinhamentos de fase PmP para o segmento negativo (noroeste) dos pontos de tiro PT-09 e PT-10 exigiram que elevadas velocidades sísmicas associadas a um proeminente gradiente vertical positivo fossem incorporados entre os $\mathrm{km} 170$ e 370 da crosta inferior do modelo sísmico. O significado geotectônico dessas observações será discutido no próximo capítulo.

Os ajustes para os alinhamentos de fase PmP do ponto de tiro PT-06, para noroeste, e para o alinhamento de fase Pn do ponto de tiro PT-15 ficaram inferiores ao esperado. A discrepância entre a leitura e a modelagem do alinhamento de fase PmP do PT-06 (ver figura 5.7) se dá pela baixa razão-sinal ruído desta seção sísmica. Uma vez considerada que a identificação de fases PmP observáveis foi realizada corretamente, e que as curvas PmP dos pontos de tiro vizinhos (PT-04, PT-05 e PT-07) estão ajustadas, a ausência de ajuste para a fase PmP do PT-06 pode ser atribuída ao limite sísmico crosta-manto nesta região do perfil, onde possivelmente há fases PmP "reverberantes" não identificadas ou, alternativamente, ao posicionamento lateral da rampa noroeste definida pela descontinuidade mesocrustal.

O ajuste para o alinhamento de fase Pn do ponto de tiro PT-15 também ficou além da incerteza considerada. Este alinhamento de fase exigia um enorme gradiente vertical positivo para o manto superior da porção noroeste do perfil sísmico. Tal gradiente estaria em desacordo com os ajustes obtidos para os alinhamentos de fase Pn dos outros pontos de tiro. Uma possibilidade é a de que este elevado gradiente vertical requerido indique um corpo lenticular de alta velocidade sísmica localizado em alguma porção do manto superior sob o perfil, e cujos raios do ponto de tiro PT-15 foram os únicos a atravessá-lo. Este seria um indício da heterogeneidade do manto litosférico sob a Bacia do Paraná.

Considerando as limitações, incertezas e ambiguidades inerentes ao método sísmico de refração/reflexão de ângulo amplo, tais como: a subjetividade na interpretação das fases, a imprecisão na determinação das leituras, amostragem espacial relativamente descontínua (região dos pontos de tiro PT-05 e PT-06), complexidade geológica e a simplicidade do modelo almejado (a busca pelo princípio da Navalha de Occam), pode-se considerar os ajustes obtidos bons e o modelo representativo da estrutura da litosfera sob o perfil sísmico. 


\section{CAPÍTULO 6 - O MODELO SÍSMICO: RESULTADOS E DISCUSSÕES}

A modelagem direta do tempo de trânsito dos alinhamentos de fases observados nas treze (13) seções sísmicas produziu modelo de velocidade de ondas $\mathrm{P}$ da estrutura da crosta e do topo do manto ao longo do perfil PABBRISE (Figuras 6.1 e 6.2). O modelo obtido possui $700 \mathrm{~km}$ de extensão e $90 \mathrm{~km}$ de profundidade, e é constituído de cinco camadas, da mais superficial para a mais profunda: 1) derrames basálticos da Formação Serra Geral; 2) rochas sedimentares pré-vulcânicas (Mesozóico/Paleozóico); 3) crosta superior; 4) crosta inferior e 5) topo do manto superior (semi-espaço). Apesar da porção noroeste do perfil sísmico atravessar porções do Grupo Bauru, topo da Bacia do Paraná, ele não foi considerado no modelo devido à sua espessura pouco significativa em relação à escala do experimento. Os parâmetros finais do modelo e das camadas sísmicas são resumidos na tabela 6.1.

O modelo é discutido com base na geometria e na distribuição da estrutura de velocidade das três principais entidades modeladas: Bacia do Paraná, crosta continental e manto superior.

Tabela 6.1 Resumo dos parâmetros do modelo sísmico PABBRISE obtido a partir de modelagem direta do tempo de trânsito das ondas P por meio do pacote de programas RAYINVR/vmed (Zelt \& Smith, 1992).

\begin{tabular}{|c|c|c|c|c|c|c|c|}
\hline \multicolumn{8}{|l|}{ 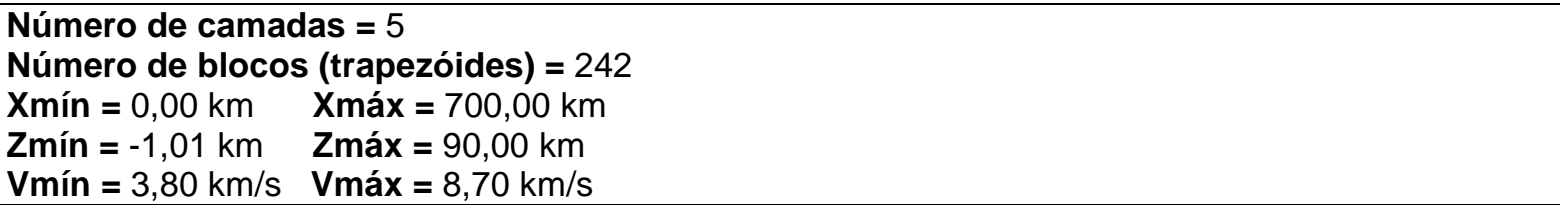 } \\
\hline Feição geotectônica modelada & Camada & $\# \mathbf{N}$ & \#V1 & \#V2 & $\overline{\mathbf{Z}} \mathbf{( k m )}$ & $\overline{\mathrm{V1}}$ (km/s) & $\overline{\mathrm{V2}}$ (km/s) \\
\hline Derrames basálticos (Fm. Serra Geral) & 1 & 76 & 9 & 9 & $-0,59$ & 4,46 & 4,48 \\
\hline Rochas sedimentares (Bacia do Paraná) & 2 & 46 & 9 & 9 & $-0,10$ & 3,82 & 3,86 \\
\hline Crosta superior & 3 & 30 & 8 & 8 & 1,37 & 6,11 & 6,36 \\
\hline Crosta inferior & 4 & 14 & 11 & 11 & 24,18 & 6,61 & 6,92 \\
\hline \multirow[t]{2}{*}{ Topo do manto superior } & 5 & 20 & 4 & 4 & 38,94 & 8,05 & 8,35 \\
\hline & Base & 1 & & & 90,00 & & \\
\hline
\end{tabular}




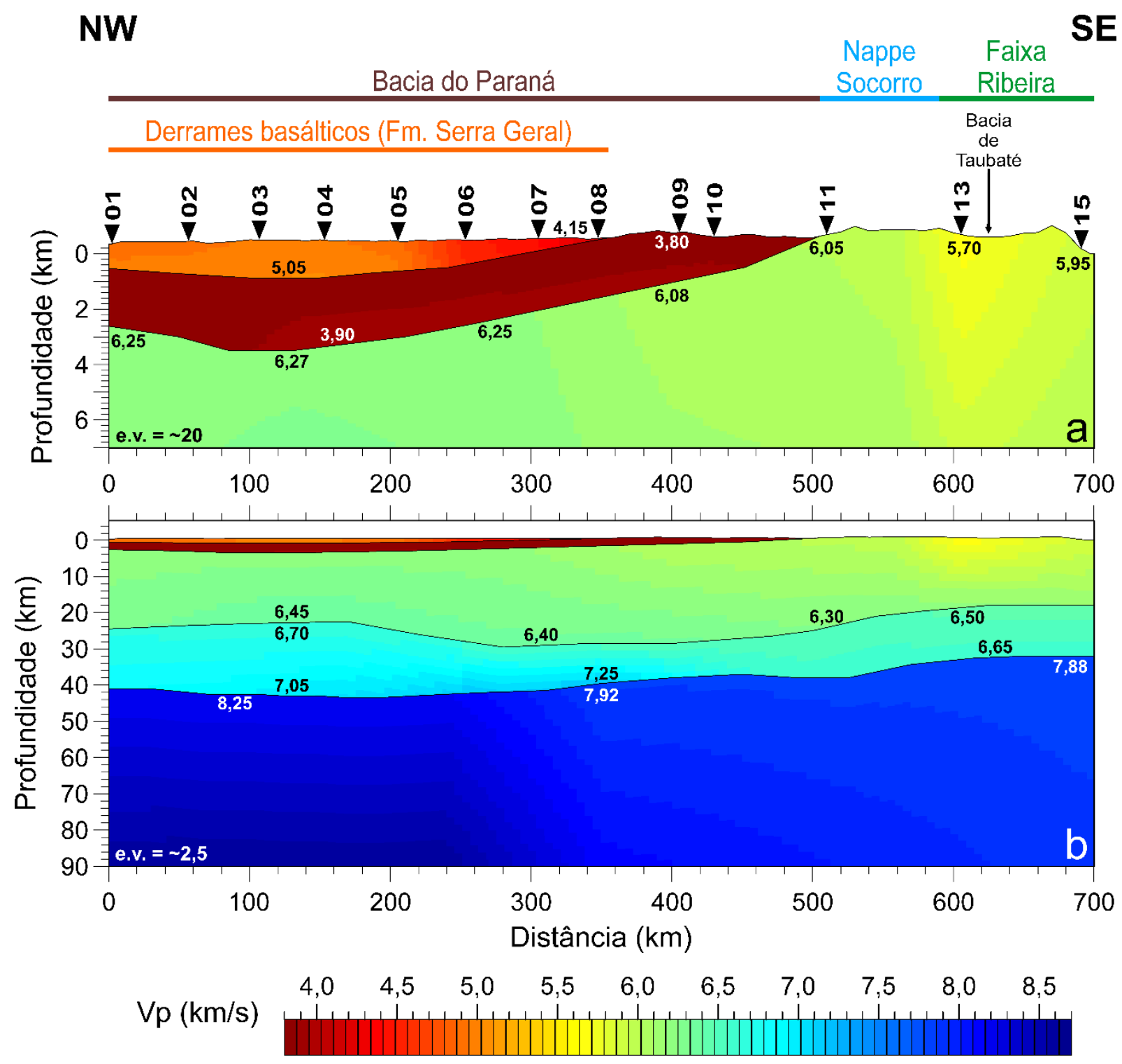

Figura 6.1 Modelo bidimensional de velocidade sísmica de ondas P para a crosta e manto superior derivado por modelagem direta do traçado de raios por meio do pacote de programas RAYINVR/vmed (Zelt \& Smith, 1992) ao longo do perfil PABBRISE. a) Enfoque na porção superior do modelo. Exagero vertical (e.v.) de 20:1. b) O modelo completo. Exagero vertical (e.v.) de 2,5:1. Os triângulos pretos demonstram as posições dos pontos de tiro (PT-01-11, 13 e 15). Os números em cada camada indicam a Vp (em km/s) para a região. Os limites geotectônicos em superfície estão indicados na porção superior da figura. 

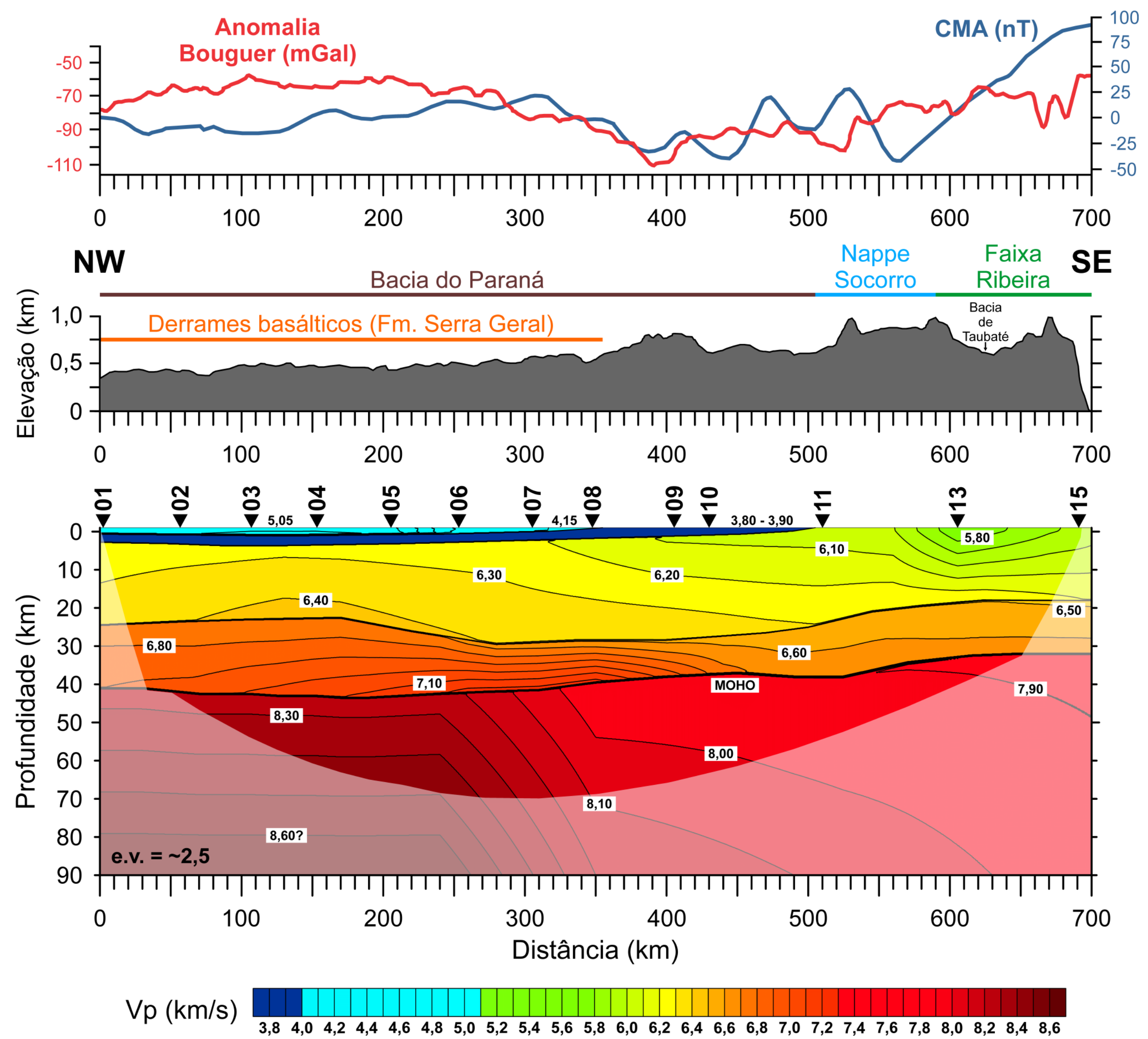

Figura 6.2 Modelo sísmico apresentado em linhas de isovelocidade (diagrama inferior) acompanhado de topografia (ETOPO1 - Amante \& Eakins, 2009) (diagrama intermediário), e anomalia Bouguer (WGM2012 - Bonvalot et al., 2012) e campo magnético anômalo - CMA (EMAG2 - Maus, 2009) (diagrama superior) obtidos, principalmente, a partir de sensores orbitais. Diagrama inferior (modelo): Os números inseridos nos retângulos brancos indicam a Vp (em km/s). As linhas de isovelocidade são espaçadas de $0,10 \mathrm{~km} / \mathrm{s}$. Os triângulos pretos demonstram as posições dos pontos de tiro (PT-01-11, 13 e 15). A porção do modelo sem transparência indica onde há cobertura de raios utilizados na construção do modelo. Exagero vertical (e.v.) de 2,5:1. Os limites geotectônicos em superfície estão indicados junto à topografia. 


\subsection{Bacia do Paraná}

Como relatado na análise das seções sísmicas, a estrutura de velocidade da Bacia do Paraná possui variações laterais e vertical (inversão de velocidade) significativas (Figura 6.1a).

O controle pelas isópacas (Zalán et al., 1990) revela espessura máxima por volta de 900 m para os derrames basálticos entre os km 105 e 145 do perfil sísmico. Nesta mesma região também ocorrem as maiores velocidades para a camada de basaltos $(\mathrm{Vp}=4,98-5,05 \mathrm{~km} / \mathrm{s})$. Tanto a espessura quanto a velocidade dos derrames basálticos são reduzidas gradualmente para sudeste. Um marco importante nesse gradiente lateral fica próximo ao km 240 do perfil. A sudeste deste ponto a espessura total dos basaltos não ultrapassa $500 \mathrm{~m}$, desaparecendo próximo ao $\mathrm{km}$ 356. Concomitantemente com o afinamento dos derrames para sudeste, a Vp passa de 4,64-4,68 km/s, próximo ao $\mathrm{km} \mathrm{240,} \mathrm{para} 4,15 \mathrm{~km} / \mathrm{s}$ no $\mathrm{km} 356$ do perfil.

As velocidades obtidas para os basaltos $(\mathrm{Vp}=4,15$ a $5,05 \mathrm{~km} / \mathrm{s}$ ) refletem a heterogeneidade primária e alterações secundárias dos derrames basálticos da Formação Serra Geral. Planke \& Cambray (1998) obtiveram Vp média de 4,17 km/s para a pilha de derrames basálticos da margem sudeste da Groenlândia. Os autores referem que a distribuição de velocidade é em geral bimodal, com velocidades que aumentam com a profundidade, de 2,50 a $5,50 \mathrm{~km} / \mathrm{s}$ no topo brechado e vesiculado dos derrames, e velocidades mais uniformes, entre 5,00 e $6,00 \mathrm{~km} / \mathrm{s}$, nas porções maciças próximas ao centro e à base dos derrames. As variações da Vp são atribuídas a mudanças sistemáticas na porosidade total, geometria dos poros, espessuras dos derrames e alterações mineralógicas secundárias.

Sob a camada de basaltos há o pacote de rochas sedimentares mesozóicas/paleozóicas da Bacia do Paraná. Este pacote possui espessura máxima de pouco mais de $2.600 \mathrm{~m}$ entre os km 85 e 131 do perfil e, como nos derrames basálticos, torna-se progressivamente menos espesso para sudeste (Bizzi et al., 2003), com o limite lateral da bacia com seu embasamento situando-se próximo ao $\mathrm{km} 505$. Como a maior parte do pacote de rochas sedimentares está sob a Formação Serra Geral, não foi possível a obtenção direta da distribuição de velocidade nesta camada do modelo sísmico, exceto em sua porção aflorante (entre os km 356 e 505). Nessa porção não há influência dos derrames basálticos, tão somente de soleiras, e provavelmente outras estruturas intrusivas menores. A partir das ondas diretas (Psed) fornecidas pelos pontos de tiro PT-09 e PT-10 foi definida Vp = 3,80-3,90 km/s para este pacote. Estes valores foram extrapolados para a porção dessa camada sísmica sob os basaltos a fim de permitir e simplificar a modelagem das camadas mais profundas. 
Outra feição estrutural importante presente na Bacia do Paraná pode ser observada do km 0 ao 106. Nessa porção do perfil tanto os derrames basálticos quanto o pacote sedimentar se tornam menos espessos para noroeste, atingindo $540 \mathrm{~m}$ e $2.080 \mathrm{~m}$ de espessura, respectivamente. Muito provavelmente esta estrutura desempenhou papel importante na origem e evolução da Bacia do Paraná, podendo estar diretamente relacionada com a implantação do vulcanismo Três Lagoas (Ordoviciano) e/ou Serra Geral (Cretáceo) nessa região.

\subsection{Estrutura de velocidade da crosta continental}

Com base na geometria crustal obtida, a estrutura de velocidade sísmica da crosta continental pode ser segmentada e descrita em três domínios sísmicos (Figuras 6.1 e 6.2):

\subsubsection{Distância no perfil: $\mathrm{km} 0$ ao 170}

A crosta continental deste domínio possui aproximadamente 38,2-40,3 km de espessura (não considerando as camadas da Bacia do Paraná). A crosta superior tem entre 19,2-21,9 km de espessura e $\mathrm{Vp}=6,25-6,45 \mathrm{~km} / \mathrm{s}$, sendo que seu topo (embasamento da Bacia do Paraná) mostra $\mathrm{Vp}=6,25-6,27 \mathrm{~km} / \mathrm{s}$. A descontinuidade mesocrustal, que separa a crosta continental em superior e inferior, ocorre em profundidades de 22,5-24,5 km. A crosta inferior tem espessuras entre 16,5 e 21,0 km e estrutura de velocidade mais heterogênea, com Vp =6,70$7,10 \mathrm{~km} / \mathrm{s}$. As velocidades Vp médias para todo o pacote crustal (incluindo a Bacia do Paraná) deste domínio ficam entre 6,18 e $6,25 \mathrm{~km} / \mathrm{s}$.

A geometria da descontinuidade mesocrustal, as velocidades Vp obtidas para a crosta inferior, características de composição máfico-intermediária (Christensen \& Mooney, 1995), e a observação de reverberações sísmicas descontínuas exclusivas à crosta inferior (Figura 6.3), são indicativas de uma crosta inferior repleta de intrusões máficas tabulares (diques e principalmente soleiras). Cenários semelhantes também foram observados em outras regiões do planeta (Enderle et al., 1997; Nielsen \& Thybo, 2009; Sandrin et al., 2009; Thybo \& Nielsen, 2012; Thybo \& Artemieva, 2013). Por análise qualitativa da seção sísmica PT-01 foi definido que estas intrusões máficas (i.e. gabróicas) são pouco espessas (geralmente entre 300 e 500 m, Thybo \& Artemieva, 2013), descontínuas e estão disseminadas na crosta inferior, do km 0 ao km 100 do perfil, dado que a partir da seção sísmica do ponto de tiro PT-02 já não são mais 
observadas reverberações significativas para as fases que trafegam na crosta inferior (ver seção sísmica do PT-02, figura 5.3).

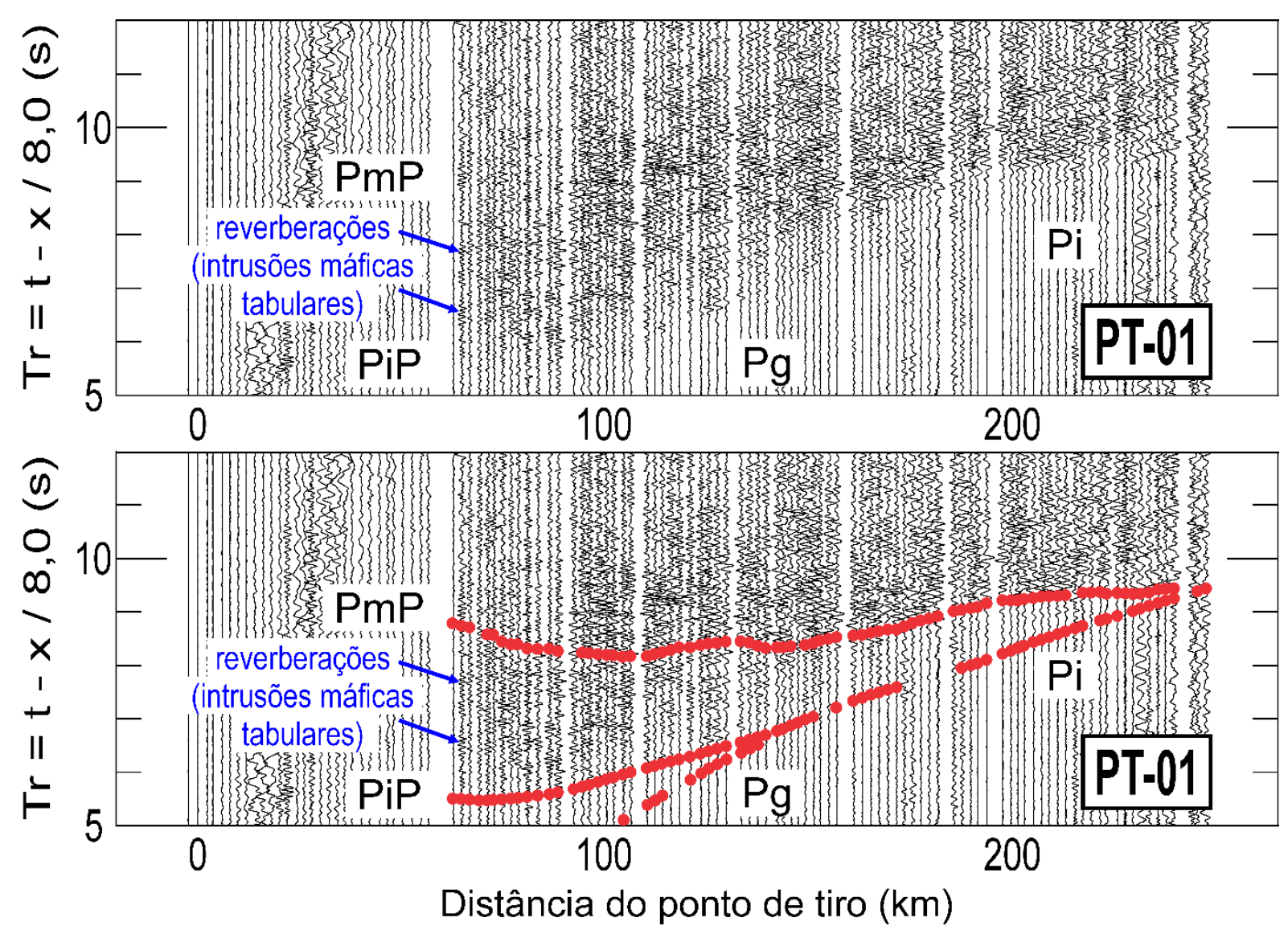

Figura 6.3 Detalhe da seção sísmica PT-01 equivalente ao espaço entre o topo (reflexão PiP) e a base (reflexão PmP) da crosta inferior. Neste intervalo (i.e. crosta inferior) ocorrem inúmeras reverberações sísmicas descontínuas (exemplificadas pelas setas azuis), indicando que parte da crosta inferior está repleta de intrusões máficas tabulares (principalmente com geometria de soleiras).

\subsubsection{Distância no perfil: $\mathrm{km} 170$ ao 525}

Este é o domínio crustal de maior heterogeneidade. A crosta continental possui espessuras entre aproximadamente 36,5 e 40,3 km (não considerando as camadas de rochas da Bacia do Paraná), com a menor espessura crustal próximo ao km 450 do perfil sísmico. Há grande diferença de parâmetros sísmicos e estruturais entre a crosta superior e a inferior desse domínio. A crosta superior é a mais espessa de todo o perfil, com espessuras entre 19,2 e 27,2 $\mathrm{km}$ e $\mathrm{Vp}=6,04-6,44 \mathrm{~km} / \mathrm{s}$. Seu topo (embasamento da Bacia do Paraná) possui Vp $=6,04$ $6,26 \mathrm{~km} / \mathrm{s}$, cenário que reflete considerável variação lateral de velocidade, e que pode 
representar passagem lateral entre meios com diferentes propriedades sísmicas. No entanto, a passagem ao longo dos $355 \mathrm{~km}$ de extensão deste domínio é gradual, o que torna difícil a definição de um limite sísmico lateral para o embasamento da bacia. A descontinuidade mesocrustal ocorre em profundidades entre 22,5 e $29,5 \mathrm{~km}$. A crosta inferior é a mais heterogênea de todo o perfil, com espessuras entre 9,5 e 21,0 km e estrutura de velocidade bastante ampla $(\mathrm{Vp}=6,55-7,25 \mathrm{~km} / \mathrm{s})$. Uma região de elevado gradiente vertical positivo e altas velocidades $(\mathrm{Vp}=7,10-7,25 \mathrm{~km} / \mathrm{s})$ é identificada na base da crosta inferior, aproximadamente entre os km 170 e 370 do perfil. Esta estrutura de velocidade provavelmente resulta de underplating máfico localizado. As velocidades Vp médias para todo o pacote crustal (incluindo a Bacia do Paraná) deste domínio ficam entre 6,05-6,25 km/s, a maior variação de todo o perfil.

A observação de que a crosta superior deste domínio é significativamente mais espessa do que a inferior (em algumas porções quase três vezes mais), fornece evidência de que possa ter havido significativo desacoplamento entre a crosta superior e a inferior, de modo que houve intenso retrabalhamento e afinamento dúctil da crosta inferior, possivelmente relacionados à ruptura de Pangea e abertura do Oceano Atlântico Sul no Cretáceo e/ou a processos desencadeados posteriormente. Aparentemente a crosta superior foi poupada da deformação dúctil e, portanto, sua espessura e estrutura de velocidade remontariam ao Pré-Cambriano.

\subsubsection{Distância no perfil: $\mathrm{km} 525$ ao 700}

Este domínio sísmico crustal marca passagem brusca de crosta relativamente espessa, com 38,9 km a noroeste, para crosta continental afinada, com 32,0 km no extremo sudeste do perfil. A crosta superior tem entre 18,0 e $23,7 \mathrm{~km}$ de espessura e $\mathrm{Vp}=5,70-6,30 \mathrm{~km} / \mathrm{s}$. O topo da crosta superior mostra $\mathrm{Vp}=5,70-6,04 \mathrm{~km} / \mathrm{s}$, com gradiente de velocidade lateral significativo próximo ao $\mathrm{km} 560$. A menor velocidade crustal de todo o perfil $(\mathrm{Vp}=5,70 \mathrm{~km} / \mathrm{s})$ está localizada na região próxima ao km 605. Em superfície esta velocidade está relacionada ao Granito Morro Azul/Igaratá (onde foi realizado o ponto de tiro PT-13) e a diversos depósitos sedimentares do Cenozóico. A descontinuidade mesocrustal ocorre em profundidades entre 18,0 e 22,8 km. A crosta inferior deste domínio é bastante peculiar. Possui espessuras entre 14,0 e 15,2 km e estrutura de velocidade anomalamente baixa, com $\mathrm{Vp}=6,48-6,65 \mathrm{~km} / \mathrm{s}$. Estes valores são muito inferiores aos de uma crosta continental inferior típica, normalmente de 
composição intermediária à máfica e com $\mathrm{Vp} \geq 6,80 \mathrm{~km} / \mathrm{s}$ (Christensen \& Mooney, 1995). As velocidades Vp médias para todo o pacote crustal deste domínio ficam entre 6,10 e $6,19 \mathrm{~km} / \mathrm{s}$. Estes valores também estão abaixo da média crustal global, que é de $6,45 \mathrm{~km} / \mathrm{s}$ (Christensen \& Mooney, 1995). Tanto a espessura quanto os valores de Vp obtidos inviabilizam a idéia de que a crosta do domínio possua origem cratônica, ou seja, o limite do Cráton do São Francisco em profundidade ocorre mais a norte.

A estrutura de velocidade sísmica da crosta inferior e a geometria crustal do domínio são fortes indícios de que toda a crosta foi modificada por processos dinâmicos. Ausência de uma crosta inferior intermediária a máfica característica e de uma raiz crustal compensando a proeminente topografia das serras do Mar e da Mantiqueira sugerem que delaminação da crosta inferior, e de parte do manto litosférico, tenha sido responsável pelos eventos tectonomagmáticos (i.e. magmatismo alcalino, riftes cenozóicos) ocorridos nessa região após a abertura do Atlântico Sul ( 90-66 Ma, Zalán \& Oliveira, 2005). O processo de delaminação tipicamente resulta em baixas Vp para a crosta inferior (Ruppert et al., 1998). O repentino afinamento de todo o pacote crustal no sentido da costa coincide com significativo aumento da anomalia Bouguer (diagrama superior da Figura 6.2), demonstrando que o limite crosta-manto tende a ser a atual superfície de compensação isostática da região.

Peixoto (2015) obteve média de 1,79 para as razões $\mathrm{Vp} / \mathrm{Vs}$ da crosta dessa região da Faixa Ribeira central sob o perfil. Razões Vp/Vs não são sensíveis a pressão e temperatura subsolidus, mas dependem da pressão de fluido, trama (anisotropia) e composição da rocha, especialmente do conteúdo de quartzo e da composição do plagioclásio (Christensen, 1996; Musacchio et al., 1997; Lowry \& Pérez-Gussinyé, 2011). O valor Vp/Vs obtido (Peixoto, 2015) é intrigante, uma vez que as Vp da crosta desse domínio são baixas e suportam composições félsicas a, no máximo, intermediárias. Supondo que a crosta superior tenha composição félsica/ácida $(\mathrm{Vp} / \mathrm{Vs} \leq 1,73)$, a crosta inferior deveria ser a responsável por contribuir com composições básico-ultrabásicas (Vp/Vs $\geq 1,77$ ), explicando a elevada Vp/Vs crustal observada (Peixoto, 2015) para a região. Entretanto, este não é o caso, visto que as $\mathrm{Vp}=6,48-6,65 \mathrm{~km} / \mathrm{s}$ obtidas para a crosta inferior estão longe de caracterizar a presença de rochas máficas ou anortosíticas (Christensen \& Mooney, 1995), e a anisotropia crustal da região é incipiente (Peixoto, 2015). A constatação leva a especular a possível ocorrência de fluidos ou fases hidratadas na crosta inferior do domínio, sugerindo forte correlação com o processo de delaminação e soerguimento topográfico regional mencionados. 


\subsection{A Moho ao longo do perfil}

Desde de sua primeira identificação no início do século XX, a Moho era entendida simplesmente como um limite de primeira ordem associado a proeminente "salto" na velocidade sísmica. Com os avanços tecnológicos em aquisição, processamento e interpretação de dados sísmicos, esta visão vem sendo alterada nos últimos anos. A Moho continental passa a ser visualizada como uma interface dinâmica, muitas vezes transicional e heterogênea (Meissner, 1973; Enderle et al., 1997; Cook et al., 2002; Carbonell et al., 2013).

A crosta ao longo do perfil sísmico PABBRISE mostra consideráveis variações na profundidade e características do limite crosta-manto sísmico (Figuras 6.1 e 6.2). As profundidades obtidas ao longo do perfil variam entre 32,0 e 43,5 km. Valores semelhantes foram obtidos por França \& Assumpção (2004) e Julià et al. (2008) pelo método de função do receptor em estações próximas ao perfil sísmico. Entretanto, os autores utilizaram valores de Vp média crustal entre 6,40 e $6,50 \mathrm{~km} / \mathrm{s}$ para o cálculo das espessuras crustais. Tais valores são significativamente maiores do que os obtidos no presente trabalho $(6,05-6,25 \mathrm{~km} / \mathrm{s})$.

No extremo noroeste do perfil, entre os $\mathrm{km} 0$ e 170, a profundidade da descontinuidade de Moho é relativamente uniforme (41,0-43,5 km). O topo do manto litosférico, logo abaixo da descontinuidade, é bastante estruturado, com pelo menos três alinhamentos de fase pós-PmP (Figura 6.4). A estrutura revelada por estes alinhamentos é peculiar, com diversos refletores mantélicos que, muito provavelmente, foram formados pelos eventos tectono-magmáticos (e.g. underplating) que afetaram a região no Ordoviciano (Basalto Três Lagoas), e posteriormente, no Cretáceo (magmatismo Serra Geral). 

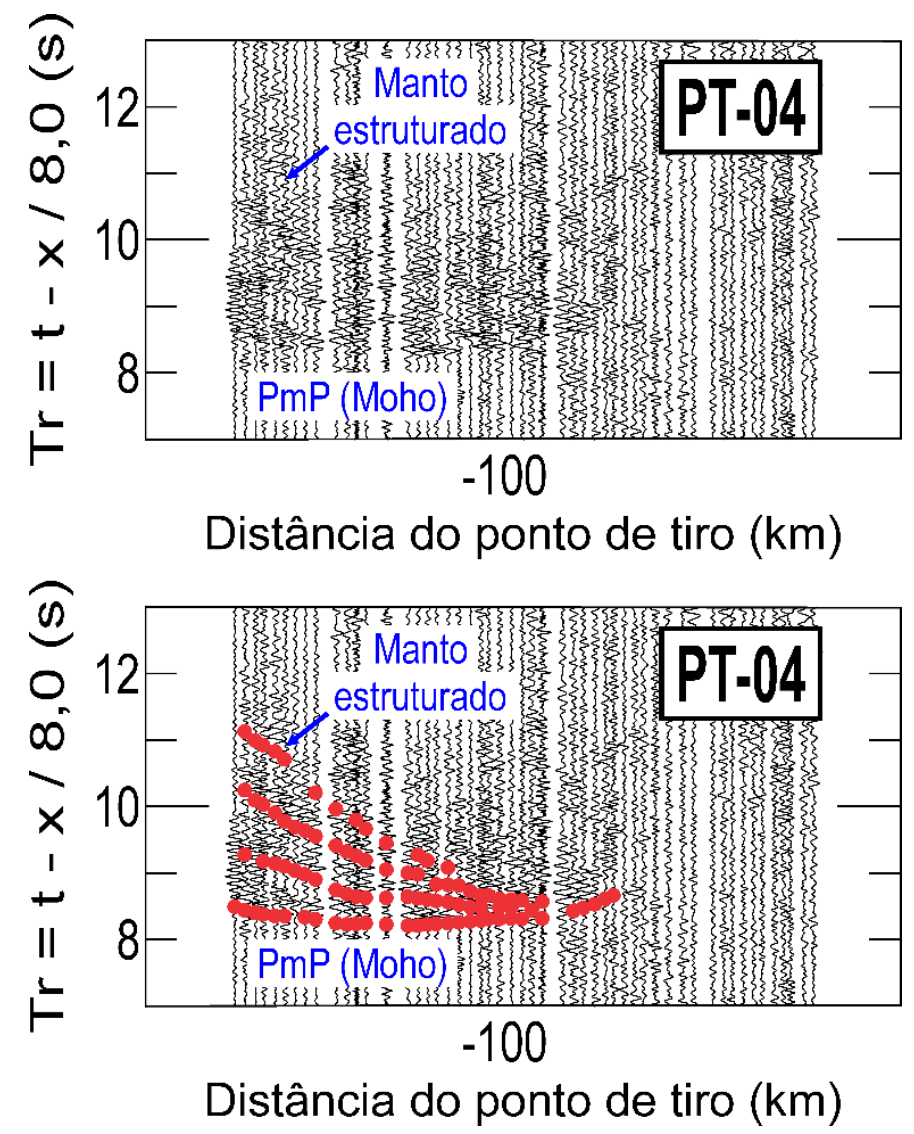

Figura 6.4 Detalhe da seção sísmica PT-04 (para noroeste) equivalente ao espaço entre a base da crosta (Moho, reflexão $\mathrm{PmP}$ ) e o topo do manto litosférico (pelo menos três reverberações coerentes pós-PmP). Este cenário mostra que o topo do manto litosférico é fortemente estruturado e o limite crosta-manto sísmico não corresponde necessariamente a uma "clássica" descontinuidade de primeira ordem.

No domínio central, entre os km 170 e 525, há maior oscilação de profundidade. A Moho tende a ficar gradualmente mais rasa do $\mathrm{km} 170(43,5 \mathrm{~km})$ até o km $450(37,0 \mathrm{~km})$. Entre os km 450 e 525 há uma interrupção deste padrão e a profundidade aumenta para $38 \mathrm{~km}$. O limite crosta-manto sísmico é complexo, principalmente sob o underplating máfico (km 170370), onde as fases PmP possuem mais de um alinhamento com reverberações relativamente coerentes (Figura 6.5), em cenário semelhante ao observado e modelado por Enderle et al. (1997) (Figura 6.6).

Por último, na porção sudeste do perfil, entre os $\mathrm{km} 525$ e 700, a profundidade da Moho muda de $38 \mathrm{~km}$ para $34,3 \mathrm{~km}$ ao longo de $45 \mathrm{~km}$, e posteriormente se estabiliza em $32 \mathrm{~km}$ de profundidade, no segmento final do perfil. Neste domínio os alinhamentos PmP tendem a ser bem marcados e sem reverberações significativas, antes e depois da fase PmP, e a Moho finalmente se mostra como a "clássica" descontinuidade de primeira ordem (Figura 6.7). 


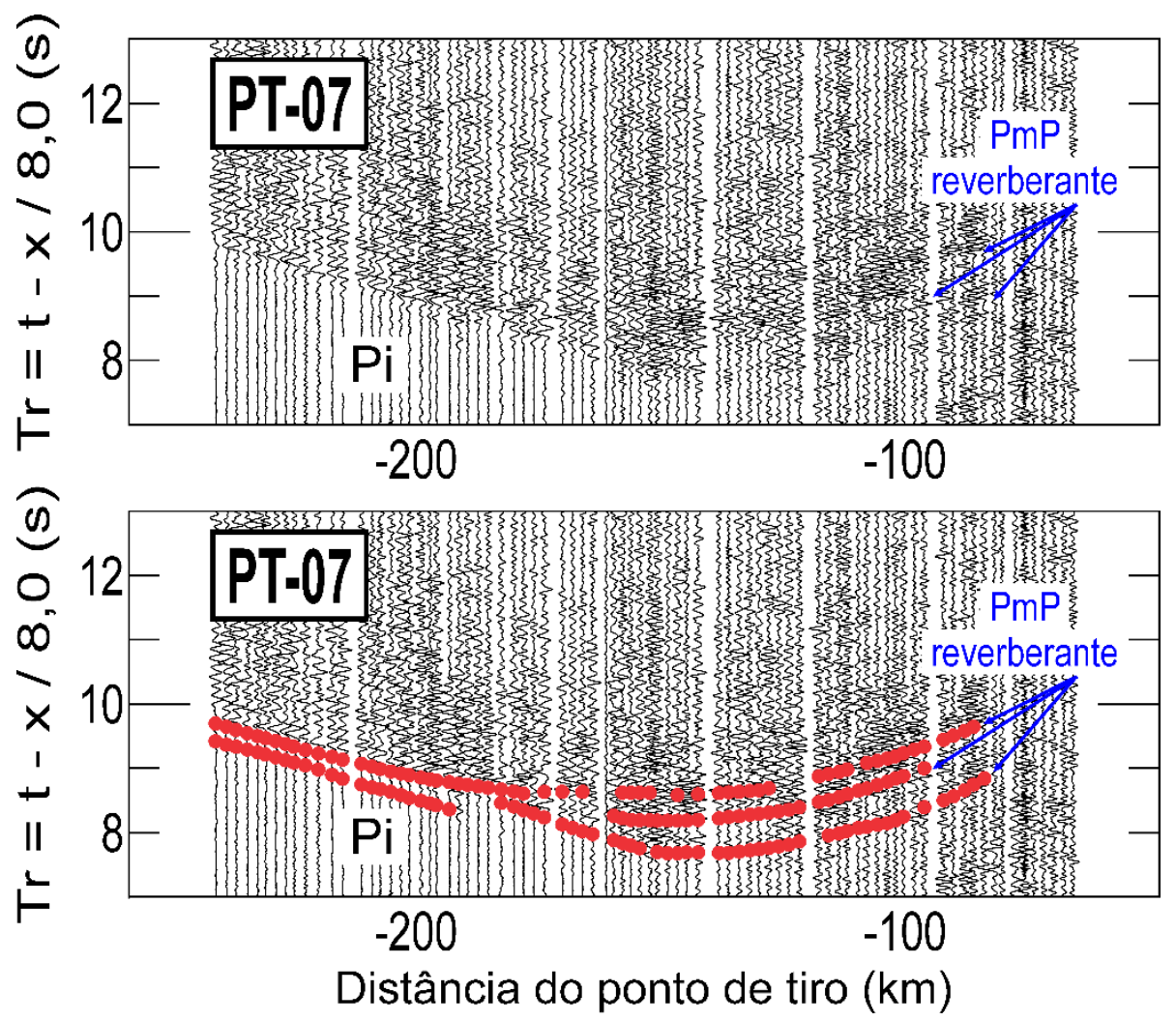

Figura 6.5 Detalhe da seção sísmica PT-07 (para noroeste) equivalente à região do limite crosta-manto sísmico (a Moho, fases PmP). Há mais de um alinhamento de fase PmP relativamente coerente, demostrando que o limitecrosta manto é complexo e estruturado, principalmente próximo à região do underplating máfico. Neste caso a Moho não é uma simples e "clássica" descontinuidade de primeira ordem.

Em trabalho recente, também pelo método WARR, Evain et al. (2015) obtiveram modelo de velocidade sísmica de ondas P para o perfil SanBa-SB01 na Bacia de Santos e margem continental sudeste. Este perfil possui superposição de aproximadamente $130 \mathrm{~km}$ com a porção sudeste final do perfil PABBRISE. Para esta região de superposição entre os modelos os autores obtiveram profundidades para a Moho por volta de $40 \mathrm{~km}$. Estas profundidades são significativamente maiores do que as obtidas no presente trabalho $(32,0-34,3 \mathrm{~km})$ e também por outros métodos geofísicos (França \& Assumpção, 2004; Araújo, 2012; Peixoto, 2015).

Os valores obtidos para a profundidade da Moho pelo método WARR (este trabalho) são iguais ou próximos aos calculados por Peixoto (2015) em método sismológico independente (função do receptor em estações de período curto) também realizado ao longo do perfil PABBRISE (Figura 6.8, Tabela 6.2). 
a

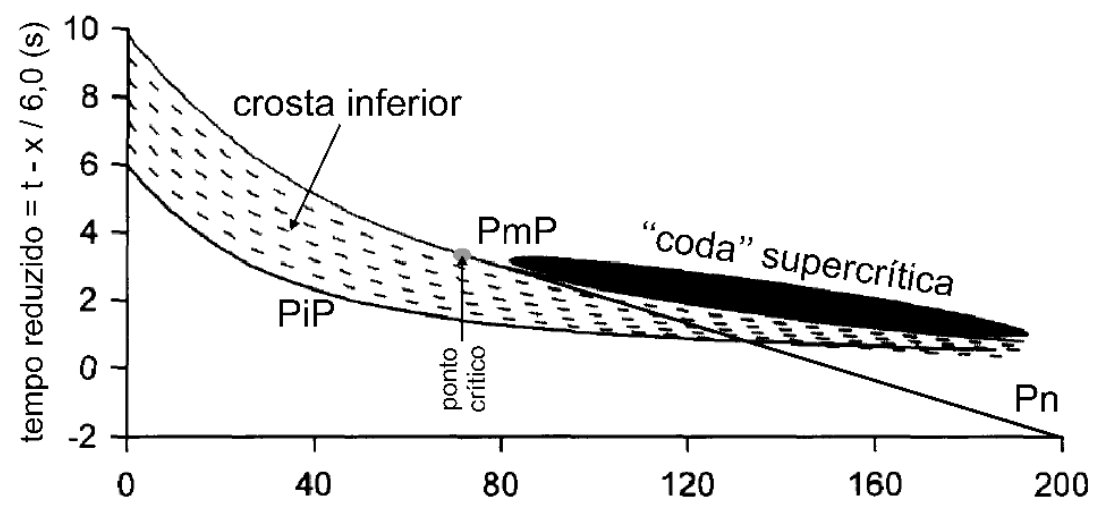

b
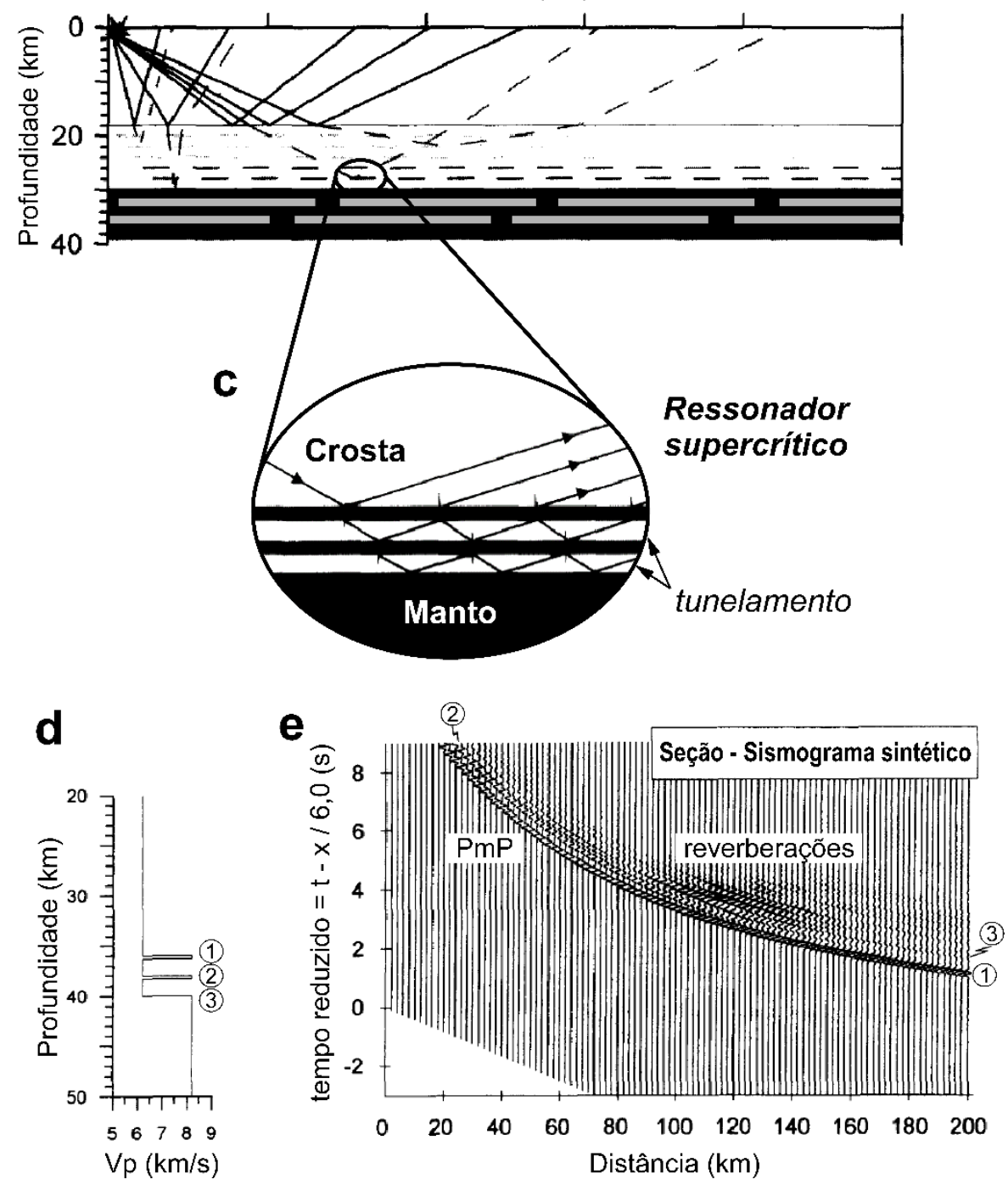

Figura 6.6 Heterogeneidade e complexidade do limite crosta-manto sísmico como observado e modelado por Enderle et al. (1997). a) Curvas tempo-distância de um diagrama de raios gerado a partir de modelo crustal simplificado (b). Neste modelo, heterogeneidades na crosta inferior e no manto são indicadas por lamelas paralelas, descontínuas e com propriedades sísmicas contrastantes ao meio em que estão inseridas. O retroespalhamento da energia sísmica observado entre as curvas das fases $\mathrm{PiP}$ e PmP (a) é causado pela estrutura interna da crosta inferior (e.g. intrusões máficas tabulares). A "coda" de reverberações supercríticas após o alinhamento PmP (a) é causada pela estrutura interna do topo do manto litosférico. c) Zoom na região do limite crosta-manto destacando o tunelamento das reflexões, formando peg-legs que compõem o padrão observado nos sismogramas. d) Modelo 1D simplificado e que emula a situação observada em (c). e) Sismograma sintético calculado a partir do modelo Vp 1-D (d). As reverberações pós-PmP corroboram a interpretação (adaptado de Enderle et al., 1997). 

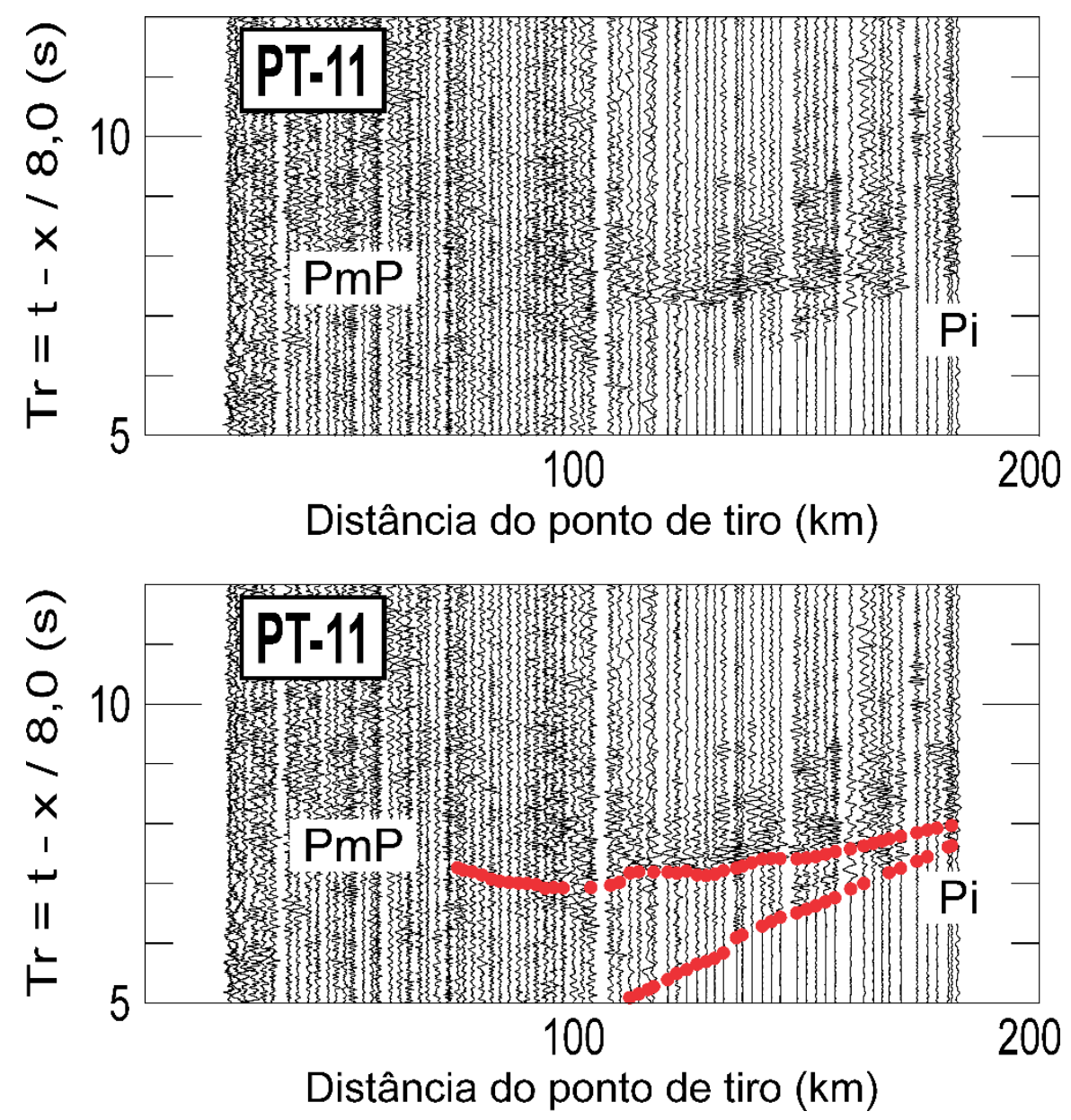

Figura 6.7 Detalhe da seção sísmica PT-11 (para sudeste) equivalente à região do limite crosta-manto sísmico (a Moho, fases PmP). A Moho se mostra como "clássica" descontinuidade de primeira ordem, não havendo reverberações significativas antes nem depois do alinhamento de fases PmP. A Moho é relativamente "lisa" (flat Moho).

Peixoto (2015) utilizou valores de Vp crustais médias obtidos pelo método WARR (6,05-6,25 km/s; presente trabalho) para o cálculo da profundidade da Moho para cada uma de suas estações correlatas ao perfil (Tabela 6.2). As profundidades obtidas pelos dois métodos são coerentes (desvio padrão $= \pm 1,33$, gráfico inferior da figura 6.8). As determinações de Peixoto (2015) corroboram os resultados obtidos no presente trabalho e reforçam a importância da interação (feedback) entre diferentes métodos, tendo sido particularmente importantes no controle das profundidades próximo às extremidades do modelo sísmico PABBRISE, onde o método WARR apresenta pouca (ou nenhuma) cobertura de raios (dados) (ver modelo, figura 6.2). As diferenças observadas para a profundidade da Moho entre os dois métodos estão condicionadas a certas limitações de ambos os métodos. O método WARR utiliza propriedades médias do meio e, portanto, tende a suavizar a geometria das interfaces. Enquanto isso, o método de função do receptor obtém profundidades relativamente pontuais sob cada estação, 
destacando variações laterais abruptas, como o "degrau" definido por Peixoto (2015) entre os $\mathrm{km} 525$ e 545 (linha preta pontilhada, figura 6.8).

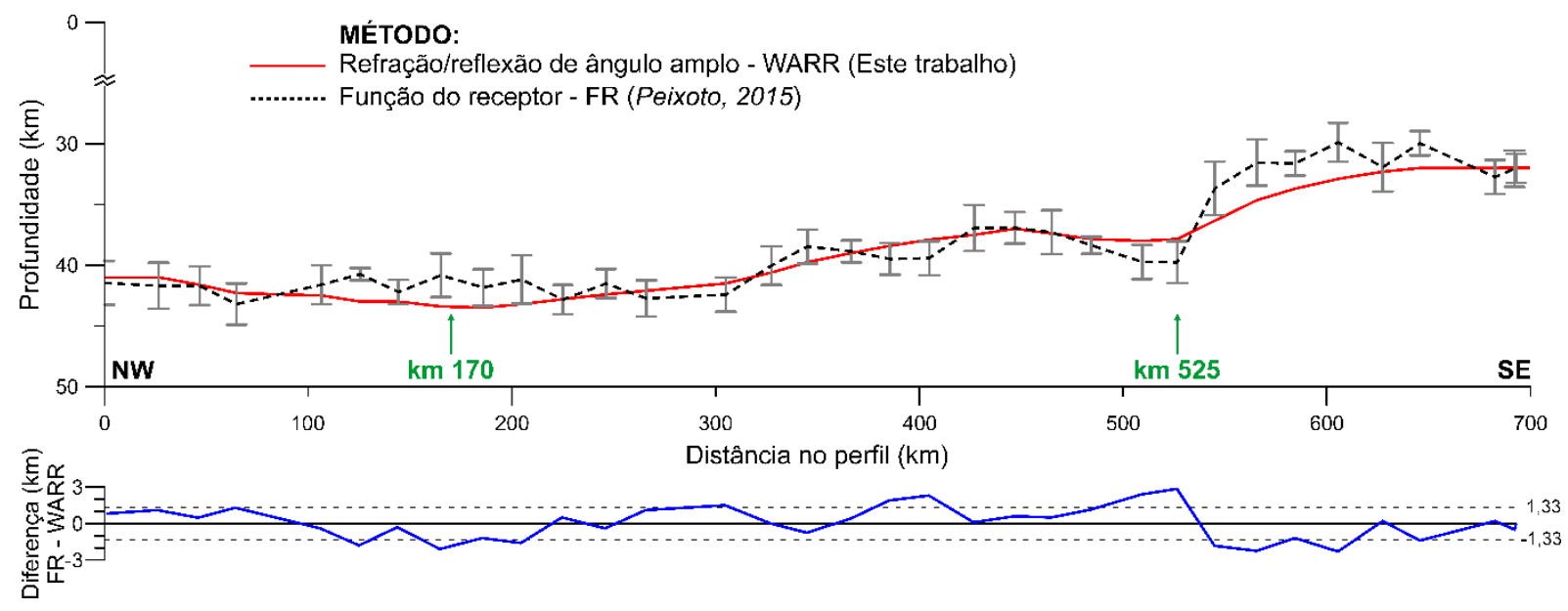

Figura 6.8 Comparação das profundidades obtidas para a descontinuidade de Moho (em km) entre o método sísmico de refração/reflexão de ângulo amplo (WARR - linha vermelha; este trabalho) e o método da função do receptor (FR - linha preta tracejada; Peixoto, 2015) (gráfico superior). A linha azul (gráfico inferior) representa a diferença FR - WARR. Desvio padrão $= \pm 1,33$. No geral, os resultados obtidos pelos métodos são coerentes entre si. É importante ressaltar que o método WARR utiliza propriedades médias do meio e, portanto, tende a suavizar o contorno das interfaces.

Tabela 6.2 Comparação entre as profundidades da Moho ao longo do perfil obtidas por Peixoto (2015) e este trabalho. Os valores de Vp média crustal fornecidos pelo método WARR foram utilizados por Peixoto (2015)

para a obtenção da profundidade da Moho por função do receptor.

\begin{tabular}{|c|c|c|c|}
\hline \multirow{2}{*}{$\begin{array}{l}\text { Domínio } \\
\text { sísmico } \\
\text { crustal }\end{array}$} & \multirow{2}{*}{$\begin{array}{c}\text { Vp média } \\
\text { para a crosta } \\
\text { (incluindo as } \\
\text { bacias) }(\mathrm{km} / \mathrm{s})\end{array}$} & \multicolumn{2}{|c|}{ Profundidade da descontinuidade de Moho (em km) } \\
\hline & & $\begin{array}{l}\text { Peixoto (2015) } \\
\text { Função do receptor }\end{array}$ & $\begin{array}{l}\text { Este trabalho } \\
\text { WARR }\end{array}$ \\
\hline km 0-170 & $6,18-6,25$ & $40,7-43,2$ & $41,0-43,5$ \\
\hline km 170-525 & $6,05-6,25$ & $36,9-42,8$ & $37,0-43,5$ \\
\hline km 525-700 & $6,10-6,19$ & $29,9-39,8$ & $32,0-38,0$ \\
\hline
\end{tabular}

\subsection{Estrutura de velocidade do manto superior}

Infelizmente não foram obtidos muitos alinhamentos de fase Pn contínuos para visualização mais completa da estrutura de velocidade do topo do manto superior. No entanto, com as leituras realizadas foi possível modelar o topo de dois domínios de manto litosférico: o "Manto Litosférico Paraná Norte" e o "Manto Litosférico Margem Sudeste". Esta nomenclatura 
visa apenas a simplificação do processo de descrição e discussão dos resultados obtidos neste trabalho.

O Manto Litosférico Paraná Norte (MLPN), como indicado pelo nome, ocorre sob parte da Bacia do Paraná. O topo de sua estrutura de velocidade é definido por $\mathrm{Vp}=8,25 \mathrm{~km} / \mathrm{s}$ entre os $\mathrm{km} 0$ e 240 do perfil sísmico. O modelo obtido sugere forte gradiente vertical positivo com o aumento da profundidade, com $\mathrm{Vp}>8,40 \mathrm{~km} / \mathrm{s}$ aos $60 \mathrm{~km}$ de profundidade. O Manto Litosférico Margem Sudeste (MLMS) é definido entre os km 350 e 700 e possui Vp =7,88$7,92 \mathrm{~km} / \mathrm{s}$ em seu topo. O modelo sugere gradiente vertical positivo suave, com $\mathrm{Vp}=8,00 \mathrm{~km} / \mathrm{s}$ aos $60 \mathrm{~km}$ de profundidade, próximo ao $\mathrm{km} 460$ do perfil. Ambos os campos de velocidade obtidos para os domínios mantélicos divergem da média global de $\mathrm{Vp}=8,07 \mathrm{~km} / \mathrm{s}$, compilada por Christensen \& Mooney (1995).

Os domínios mantélicos bastante contrastantes são separados por região de manto litosférico com estrutura de velocidade transicional ( $\mathrm{Vp}=7,92-8,25 \mathrm{~km} / \mathrm{s}$ no topo) e proeminente gradiente lateral. A porção transicional do manto aparenta ter influência maior do MLPN, observação corroborada pela forte correlação com o grande comprimento de onda do sinal de anomalia Bouguer entre os $\mathrm{km} 0$ e $~ 350$ do perfil sísmico (diagrama superior, figura $6.2)$.

As Vp obtidas estão associadas com variações composicionais e termais entre os domínios e refletem os diferentes processos geodinâmicos que os moldaram. Medidas de fluxo de calor na Bacia do Paraná indicam valores entre 40 e $50 \mathrm{~mW} / \mathrm{m}^{2}$ para a porção central da bacia e valores maiores e mais variáveis $\left(50-70 \mathrm{~mW} / \mathrm{m}^{2}\right)$ ao longo de sua margem leste, onde não há cobertura de derrames basálticos (Hurter \& Pollack, 1996). Estes autores concluem que o padrão termal observado reflete estrutura termal litosférica de grande escala, desenvolvida durante a geração e extrusão dos derrames basálticos.

Soares et al. (2006) relatam $\mathrm{Vp}=8,23 \mathrm{~km} / \mathrm{s}$ para o manto litosférico do Cráton do São Francisco. Esta Vp é semelhante à obtida para o manto litosférico sob a Bacia do Paraná (Vp = $8,25 \mathrm{~km} / \mathrm{s}$, este trabalho). Embora o regime de fluxo geotérmico para a região cratônica apresente valores heterogêneos, em geral estes são menores do que os obtidos para a região da Bacia do Paraná (Hamza \& Muñoz, 1996; Alexandrino \& Hamza, 2008). Crátons précambrianos possuem raiz litosférica fria e quimicamente empobrecida (i.e. refratária). As variações de densidade, e consequentemente, de velocidade sísmica, observadas em raízes cratônicas são controladas mais por diferenças termais do que por diferenças químicas (Kaban et al., 2003). Esta relação demonstra que diferentes fatores controlam as Vp obtidas nesses 
domínios de manto litosférico. No Cráton do São Francisco, a estrutura de velocidade Vp obtida para o manto litosférico deve-se às baixas temperaturas, enquanto a elevada $\mathrm{Vp}(8,25 \mathrm{~km} / \mathrm{s})$ do MLPN provavelmente se deve a proeminente contribuição de manto composicionalmente diferenciado (enriquecido).

Como já mencionado, ao longo do perfil sísmico, a estrutura de velocidade do MLPN ao longo do perfil sísmico, somada à do domínio de manto transicional, coincide espacialmente com região de relativamente elevada anomalia Bouguer de grande comprimento de onda e, também, com ampla depressão topográfica regional associada à Bacia do Paraná (km 0 ao 350) (Figura 6.2). Este é forte indício de que, pelo menos para essa região, o limite crosta-manto não é a superfície de compensação isostática regional. Os underplating máficos identificados pelo método WARR (km 0-370) não são volumosos e pervasivos o suficiente para serem os únicos responsáveis pela anomalia Bouguer descrita, como sugerido por Mariani et al. (2013). Esta ampla anomalia gravimétrica seria, portanto, a resposta combinada de diversas massas anômalas (possivelmente rochas máficas em fácies eclogito) em diversos níveis da litosfera, principalmente no manto litosférico, onde teria correlação com uma região relativamente condutiva e cujo topo estaria localizado a $\sim 80 \mathrm{~km}$ de profundidade (Minei, 2015). Padilha et al. (2015) sugerem que a litosfera esteja impregnada por minerais condutivos, possivelmente relacionados ao evento tectono-magmático que deu origem à bacia ou, alternativamente, por materiais residuais de origem magmática derivados a partir do Cretáceo (magmatismo Serra Geral).

\subsection{Considerações sobre a evolução da Bacia do Paraná e da margem continental sudeste brasileira}

Origem e evolução da Bacia do Paraná e da margem continental sul-sudeste brasileira estão diretamente ligadas à história tectônico-evolutiva do Gondwana Ocidental e, posteriormente, à abertura do Oceano Atlântico Sul. Entretanto, perduram muitas lacunas e questões a serem respondidas sobre essa região, principalmente no que tange à Bacia do Paraná, considerada típico exemplo de bacia cratônica (Zalán et al., 1990) e às elevações topográficas das serras do Mar e da Mantiqueira.

As bacias cratônicas são depósitos intracontinentais de subsidência prolongada e que ocorrem sobre uma variedade de substratos crustais (i.e. crátons, terrenos acrescidos, antigos 
cinturões móveis e complexos de riftes, Allen \& Armitage, 2012). Do ponto de vista geodinâmico, origem e desenvolvimento dessas bacias permanecem ainda pouco compreendidos. Inúmeros mecanismos são invocados na tentativa de explicar a origem deste tipo de bacia (Klein, 1995), e em muitos casos, bacias cratônicas existem há tempo o suficiente para terem sido afetadas e modificadas por mais de um mecanismo de subsidência e soerguimento (Allen \& Armitage, 2012).

A estrutura crustal obtida no modelo sísmico PABBRISE foi combinada com a do modelo SanBa - SB01 (Evain et al., 2015) em perfil tectônico simplificado de aproximadamente 1620 km de extensão (Figura 6.9). O cenário resultante permite tecer algumas considerações sobre o atual estado da litosfera e os possíveis eventos e mecanismos que, de algum modo, atuaram na evolução tectônica da região. A interpretação tectônica segue de maneira cronológica, desde o final do Neoproterozóico até a estruturação litosférica atual. Parte da interpretação é meramente especulativa e consiste em tentativa de contextualizar os resultados obtidos no modelo sísmico com os conhecimentos geológicos e geofísicos acumulados sobre a região ao longo dos anos por diversos pesquisadores.

Primeiramente, os eventos orogênicos ocorridos na região, do final do Neoproterozóico ao início do Paleozóico (i.e. Orogenia Brasiliana), influenciaram significativamente na definição de limites litosféricos de primeira ordem, tanto na forma de heranças litosféricas do embasamento, como na individualização de diferentes domínios de manto litosférico. Papel importante deve ser dado à subducção da litosfera oceânica da Paleoplaca São FranciscoCongo, sob a porção norte-nordeste da Bacia do Paraná e, provavelmente da litosférica oceânica de outros terrenos/blocos a oeste, Bloco Rio Apa (Woldemichael, 2003), e também a leste. Tal cenário acabou por enriquecer e individualizar um domínio de manto litosférico peculiar para esta região (Minei, 2015; Padilha et al., 2015), o Manto Litosférico Paraná Norte deste trabalho.

A principal questão é se as subducções ocorreram por sob um único núcleo cratônico (Cordani et al., 1984), "bloco" litosférico (Mantovani et al., 2005) ou "mosaico de blocos" litosféricos separados por faixas móveis brasilianas (Milani \& Ramos, 1998) (ver figura 2.3, Capítulo 2). Estudos regionais recentes envolvendo dados sismológicos (Julià et al., 2008; Rocha et al., 2011) favorecem a interpretação de Milani \& Ramos (1998). 


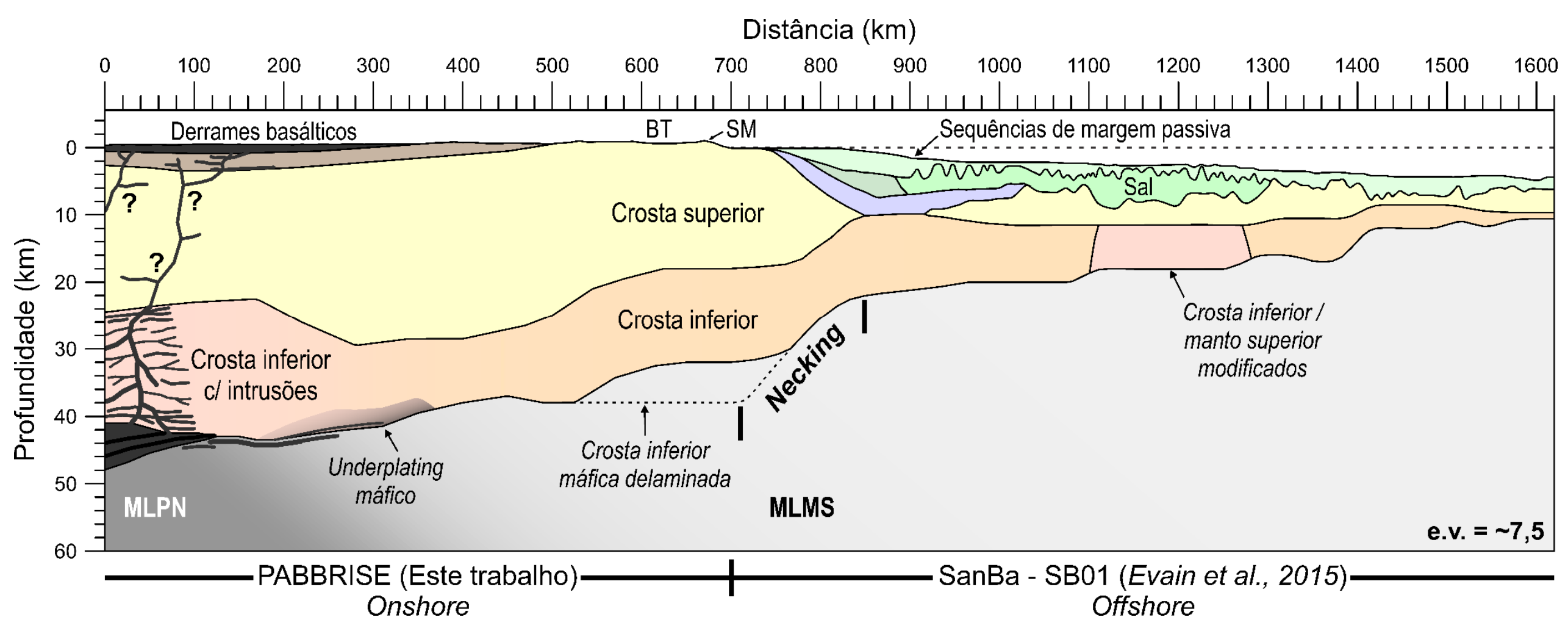

Figura 6.9 Interpretação tectônica simplificada da estrutura crustal e topo do manto superior ao longo da extensão combinada onshore-offshore (1620 km) entre os perfis sísmicos PABBRISE (este trabalho) e SB01 (Evain et al., 2015). A região do necking marca afinamento crustal abrupto. Abreviações: BT - Bacia de Taubaté; SM - Serra do Mar; MLPN Manto Litosférico Paraná Norte; MLMS - Manto Litosférico Margem Sudeste. Exagero vertical (e.v.) de 7,5:1. 
O modelo sísmico PABBRISE mostra que a crosta superior sob essa porção da Bacia do Paraná possui Vp relativamente homogênea e com gradiente lateral de velocidade suave, não acusando qualquer tipo de descontinuidade crustal de primeira ordem (e.g. sutura). A crosta inferior sob a bacia foi retrabalhada heterogeneamente (i.e. underplating máfico, a noroeste, desacoplamento e afinamento dúctil, no domínio central, e delaminação a sudeste). Resultados de razão Vp/Vs (Julià et al., 2008; Peixoto, 2015) sugerem diferentes compartimentos composicionais, mas como representam médias crustais e como a crosta inferior foi retrabalhada, não são ideais para a definição de um arcabouço para o embasamento. Além disso, o perfil sísmico PABBRISE não atravessa o domínio de "blocos" (ou cráton) como sugerido por Cordani et al. (1984) e Milani \& Ramos (1998) (ver figura 2.3, Capítulo 2), e em relação a anomalia gravimétrica utilizada para justificar a existência do Bloco Paranapanema (Quintas, 1995; Mantovani et al., 2005; Mantovani \& Brito Neves, 2009), os dados sísmicos mostram que não é compensada na crosta.

Esse cenário impossibilitou a definição de um limite crustal lateral sob a Bacia do Paraná. O traçado (em mapa) de limite para a crosta superior do "Bloco Paranapanema" permanece em aberto. A modificação/enriquecimento do manto litosférico sob a porção nortenordeste da bacia e suas consequências geodinâmicas são o foco da discussão a seguir.

O Manto Litosférico Paraná Norte é composicionalmente e, portanto, mecanicamente diferente dos mantos litosféricos sob a porção sul da Bacia do Paraná e margem continental sudeste. Esta diferença foi observada por diferentes métodos geofísicos. Estes identificam o Manto Litosférico Paraná Norte como relativamente veloz (Assumpção et al., 2004; Feng et al., 2004; Rocha et al., 2011; Chaves, 2014), condutivo (Minei, 2015; Padilha et al., 2015) e denso (Chaves, 2014). As diferenças litosféricas de primeira ordem provavelmente influenciaram significativamente a evolução da Bacia do Paraná, controlando parte de seus atuais limites, e regiões adjacentes, principalmente em relação aos esforços distensivos durante a abertura do Oceano Atlântico Sul no Cretáceo. Este evento colocou à prova toda a litosfera da região.

Do final da Orogenia Brasiliana ao início da sedimentação da superssequência basal Rio Ivaí da Bacia do Paraná, há um intervalo do tempo geológico pouco compreendido: o Cambriano. No entanto, colapso termal regional (Zalán et al., 1990) seria uma hipótese pouco provável para explicar a implantação da Bacia do Paraná durante o Meso-Ordoviciano. A ocorrência do Basalto Três Lagoas ( 443 Ma, Milani, 2004) junto à superssequência basal sugere tectônica sin-sedimentar associada a um mecanismo de rifteamento e incipiente 
estiramento litosférico ( 440 Ma, Quintas et al., 1999), que provavelmente aproveitaram transtracionalmente as estruturas brasilianas NE-SW, e foram impulsionados pelas diacrônicas fases compressivas da Orogenia Oclóyica, ocorridas na borda sul-ocidental do Gondwana (Milani \& Ramos, 1998). Neste contexto, seria improvável a existência de uma litosfera com estrutura termal de baixa temperatura sob a Bacia do Paraná àquela época.

Após esse estágio de subsidência inicial, possivelmente a intensidade da influência dos Gondwanides passou a ser mais distal e reduzida e, agora sim, colapso e contração termal litosférica significativos provavelmente tenham ocorrido. O Manto Litosférico Paraná Norte, anteriormente enriquecido e individualizado por subducção e fusão parcial da litosfera oceânica Sãofranciscana durante a Orogenia Brasiliana, passaria a apresentar um componente de densificação litosférica ativado por gradual redução regional de temperatura (i.e. colapso termal). Em determinada profundidade e sob condições de elevada razão P/T o manto litosférico enriquecido provavelmente alcançou a fácies eclogito. O processo metamórfico pode ter sido acelerado pela migração de fluidos através de profundas zonas de cisalhamento (Austrheim, 1987) remobilizadas pela influência distal dos Gondwanides. A eclogitização de manto litosférico enriquecido promoveria incremento gradual e significativo de densidade, acabando por favorecer instabilidade gravitacional (Ringwood \& Green, 1966).

Densificação litosférica combinada à influência, desta vez distal, promovida pelos Gondwanides (i.e. Orogenia Sanrafaélica, Milani \& Ramos, 1998), seriam responsáveis pelo segundo evento de estiramento litosférico localizado ( $296 \mathrm{Ma}$, Quintas et al., 1999) associado à subsidência por ampla flexura regional da litosfera. Durante este intervalo não houve magmatismo e a taxa de subsidência intracratônica cresceu significativamente (ver figura 2.2, Capítulo 2). Associada a ela, deu-se a deposição das mais proeminentes sequências sedimentares da Bacia do Paraná (Milani \& Ramos, 1998).

Ao final desse estágio o Manto Litosférico Paraná Norte estava fortemente acoplado ao substrato crustal sob a porção norte da Bacia do Paraná, e a crosta inferior próximo ao Rio Paraná (km 0-170 do modelo) provavelmente já se encontrava reologicamente mais resistente devido ao resfriamento do evento magmático Paleozóico. Desse modo, no advento da ruptura continental que culminou na abertura do Oceano Atlântico Sul, a região sobre o Manto Litosférico Paraná Norte comportou-se como "bloco" único e resistente aos esforços tracionais impostos. O magmatismo Serra Geral ( 134,7 Ma, Thiede \& Vasconcelos, 2010) provavelmente aproveitou a estrutura litosférica gerada até aquele momento (e.g. manto litosférico enriquecido, zonas de fraqueza pretéritas, crosta inferior e manto litosférico 
modificados e relativamente frios) para sua rápida, e possivelmente fissural, extrusão (Gerya \& Burg, 2007), principalmente por meio de alguma estrutura condicionada ao longo do Rio Paraná. O fator reforça ainda mais a hipótese da diferença entre dois reservatórios mantélicos sob a Bacia do Paraná. O limite litosfera-astenosfera sob a porção norte da Bacia do Paraná teria sido enriquecido ainda durante o Neoproterozóico (Rocha-Júnior et al., 2012, 2013; Padilha et al., 2015). Este cenário poderia explicar a diferença geoquímica observada entre os basaltos da porção norte da Bacia do Paraná, ricos em $\mathrm{TiO}_{2}$, e os da porção sul, pobres em $\mathrm{TiO}_{2}$ (Bellieni et al., 1984).

Durante o evento de rifteamento e principal estágio de abertura do Oceano Atlântico Sul ( 134-114 Ma, Zalán \& Oliveira, 2005), a crosta continental atualmente submersa e sob a Bacia de Santos foi hiperestendida (Evain et al., 2015) (Figura 6.9). A crosta continental hoje emersa e parte da Faixa Ribeira central no Estado de São Paulo aparentemente foi pouco ou nada afetada pelo hiperestiramento. Tal cenário resultou em crosta continental relativamente espessa ( $\geq 40 \mathrm{~km}$ ) que se afina abruptamente (região do necking, figura 6.9) para valores menores do que $15 \mathrm{~km}$ (Evain et al., 2015). Este cenário com grande variação de espessura lateral provavelmente favoreceu a formação de pequenas e localizadas células de convecção astenosférica de borda (edge-driven convection, King \& Anderson, 1998) que enfraqueceram e promoveram delaminação lateral de parte do manto litosférico e da crosta inferior sob a Faixa Ribeira central. Isto explicaria a crosta relativamente fina $(32,0-34,3 \mathrm{~km}) \mathrm{e}$ as baixas velocidades sísmicas encontradas para a base da crosta $(\mathrm{Vp}=6,65 \mathrm{~km} / \mathrm{s})$ e para o topo do manto $(\mathrm{Vp}=7,88-7,90 \mathrm{~km} / \mathrm{s})$ sob a região da Faixa Ribeira central. A delaminação de parte da litosfera (incluindo a crosta inferior) foi responsável pela anomalia térmica regional (subida da astenosfera). Esta anomalia promoveu o magmatismo alcalino e o soerguimento regional do Cretáceo Superior ( 90-66 Ma, Zalán \& Oliveira, 2005), e posterior erosão e quebramento da crosta superior, o que resultou na implantação do Sistema de Riftes Cenozóicos do Sudeste do Brasil ( 59-20 Ma, Zalán \& Oliveira, 2005). Aparentemente, a região da Faixa Ribeira central ainda possui o topo do manto litosférico relativamente aquecido $(\mathrm{Vp}=7,88-7,92 \mathrm{~km} / \mathrm{s})$, o que sugere que a energia térmica ainda não foi totalmente dissipada/reequilibrada. Neste caso a Moho é a interface de compensação isostática regional. 


\section{CAPÍTULO 7 - CONCLUSÕES}

A partir da análise das seções sísmicas do perfil PABBRISE, bem como do modelo de velocidade sísmica de ondas $\mathrm{P}$ da crosta e manto superior obtido, conclui-se que:

1) Ao longo do perfil sísmico as profundidades para a descontinuidade de Mohorovičić estão entre 32,0 e 43,5 km, com tendência de afinamento crustal no sentido da margem continental.

2) A estrutura de velocidade dos derrames basálticos da Bacia do Paraná não é uniforme, e sua variação reflete a complexidade e heterogeneidade, tanto primárias quanto secundárias, desses derrames.

3) Não foi possível definir limite lateral específico para o arcabouço crustal sob a Bacia do Paraná. O manto litosférico "cratônico" e a crosta inferior foram danificados/descaracterizados pelos processos tectono-magmáticos que afetaram a região no Ordoviciano (Basalto Três Lagoas) e Cretáceo (magmatismo Serra Geral). O traçado (em mapa) de limite para a crosta superior do "Bloco Paranapanema" permanece em aberto.

4) Não há indícios sísmicos (espessura crustal e Vp) da existência da litosfera cratônica do Cráton do São Francisco sob a porção da margem continental sudeste (Faixa Ribeira central) na região imageada pelo perfil sísmico.

5) As elevações das serras do Mar e da Mantiqueira não possuem raiz crustal. A crosta inferior, possivelmente de composição máfica, e o topo do manto litosférico sob a margem continental (Faixa Ribeira central, sudeste do perfil) foram delaminados e, com isso, houve soerguimento flexural regional e magmatismo alcalino associado. Nesta região a Moho é a interface de compensação isostática regional.

6) Há pelo menos dois domínios de manto litosférico bastante distintos ao longo do perfil sísmico: o Manto Litosférico Paraná Norte $(\mathrm{Vp}=8,25 \mathrm{~km} / \mathrm{s}$ no topo) e o Manto Litosférico Margem Sudeste ( $\mathrm{Vp}=7,88-7,92 \mathrm{~km} / \mathrm{s}$ no topo). Esses mantos são responsáveis, em parte, pelo comportamento mecânico e geodinâmico de cada região sob sua influência. 
7) Underplating máfico, no sentido amplo de Thybo \& Artemieva (2013), ocorre do km 0 ao $\mathrm{km} \sim 370$ do perfil sísmico e se manifesta com diferentes geometrias. Pelo menos parte desse magmatismo máfico deve ser anterior ao magmatismo Serra Geral, e sua existência teria facilitado e condicionado a extrusão do mais recente.

8) Os underplating máficos identificados pelo método WARR (km 0-370) não são volumosos e pervasivos o suficiente para serem os únicos responsáveis pela anomalia Bouguer de grande comprimento de onda observada na mesma região do perfil. Neste caso a Moho não é a interface de compensação isostática regional e, provavelmente, a maior parte dessa anomalia gravimétrica é proveniente de contribuição do manto litosférico enriquecido sob a porção norte-nordeste da Bacia do Paraná (MLPN).

9) O limite crosta-manto sísmico ao longo do perfil só é uma descontinuidade "clássica" de primeira ordem na região em que a crosta inferior foi delaminada (sudeste do perfil). Ao longo do restante do perfil a Moho possui trama complexa e heterogênea, muito provavelmente criada pelos processos tectono-magmáticos ocorridos no Ordoviciano e Cretáceo.

10) A estrutura composicional e termal da crosta inferior e do manto litosférico durante eventos deformacionais influenciam fortemente no comportamento reológico dos mesmos, controlando a compartimentação e evolução geotectônica de uma região, especialmente em eventos distensivos, quando realmente são colocados à prova. A atual borda nordeste da Bacia do Paraná é exemplo desse tipo de controle dinâmico.

11) A história de subsidência da Bacia do Paraná provavelmente foi dada pela combinação de diferentes mecanismos de subsidência que atuaram em diferentes momentos de sua evolução. Destaca-se, para a porção norte-nordeste da bacia, a importância do persistente acoplamento entre a crosta e o manto litosférico enriquecido e o processo de densificação litosférica associado. 


\section{REFERÊNCIAS}

ALEXANDRINO, C.H. \& HAMZA, V.M. 2008. Estimates of heat flow and heat production and a thermal model of the São Francisco craton. Int. J. Earth. Sci. (Geol. Rundsch.). Springer-Verlag. 18 p.

ALLEN, P.A. \& ARMITAGE, J.J. 2012. Cratonic basins. In: BUSBY, C.J. \& AZOR. A. (Eds.): Tectonics of sedimentary basins: Recent Advances, United Kingdom: Wiley-Blackwell. p. 602-620.

ALMEIDA, F.F.M. 1958. O Planalto Paulistano. In: Azevedo, A. A cidade de São Paulo. Associação dos Geógrafos Brasileiros, São Paulo, v. 1, p. 113-167.

ALMEIDA, F.F.M.; BRITO NEVES, B.B.; CARNEIRO, C.D.R. 2000. The origin and evolution of the South American Platform. Earth-Science Reviews, 50, p. 77-111.

ALMEIDA, F.F.M.; HASUI, Y.; BRITO NEVES, B.B.; FUCK, R.A. 1981. Brazilian structural provinces: An introduction, Earth Sci. Rev., 17, 1-29.

ALMEIDA, F.F.M. \& CARNEIRO, C.D.R. 1998. Origem e evolução da Serra do Mar. Revista Brasileira de Geociências, São Paulo, v. 28, n. 2, p. 135-150.

ALMEIDA, J.C.H.; TUPINAMBÁ, M.; HEILBRON, M.; TROUW, R.A.J. 1998. Geometric and kinematic analysis at the Central Tectonic Boundary of the Ribeira Belt, southeastern Brazil. In: SBG, Congr. Bras. Geol., vol. 40. Belo Horizonte, Anais, 32.

AMANTE, C. \& EAKINS, B.W. 2009. ETOPO1 1-Arc-Minute Global Relief Model: Procedures, Data Sources and Analysis. NOAA Technical Memorandum NESDIS NGDC-24. National Geophysical Data Center, NOAA. doi:10.7289/V5C8276M (Acessado em: 11 de outubro de 2015).

ARAÚJO, S.A.C. 2012. Métodos potenciais aplicados ao estudo do arcabouço crustal da porção meridional da Faixa Ribeira, margem continental da Bacia de Santos. Dissertação (Mestrado) - Instituto de Geociências, Universidade de Brasília. 137 p.

ASMUS, H.E. \& GUAZELLI, M. 1981. Descrição sumária das estruturas da margem continental brasileira e das áreas oceânicas e continentais adjacentes, hipóteses sobre o tectonismo causador e implicações para os prognósticos de recursos minerais. In: PETROBRÁS. Estruturas e tectonismo da margem continental brasileira, e suas implicações nos processos sedimentares e na avaliação do potencial de recursos minerais; relatório final. Rio de Janeiro, CENPES/DINTEP. p. 187-269. (Projeto REMAC 9).

ASSUMPÇÃO, M.; JAMES, D.; SNOKE, A. 2002. Crustal thicknesses in SE Brazilian shield with receiver function: implications for isostatic compensation. Journal of Geophysical Research, United States of America, v. 107, n. B1, p. 2-1-2-14.

ASSUMPÇÃO, M.; SCHIMMEL, M.; ESCALANTE, C.; BARBOSA, J.R.; ROCHA, M.; BARROS, L.V. 2004. Intraplate seismicity in SE Brazil: stress concentration in lithospheric thin spots. Geophys. J. Int.159, 390-399.

AUSTRHEIM, H. 1987. Eclogitization of lower crustal granulites by fluid migration through shear zones. Earth and Planetary Science Letters, 81. p. 221-232.

AZEVEDO, P.A.; ROCHA, M.P.; SOARES, J.E.P.; FUCK, R.A. 2015. Thin lithosphere between the Amazonian and Sao Francisco cratons, in central Brazil, revealed by seismic P-wave tomography. Geophysical Journal International, v. 201, p. 61-69.

BASSINI, A.M. 1986. Levantamentos sismográficos na região sudeste do Brasil. Dissertação de Mestrado, Instituto de Astronomia, Geofísica e Ciências Atmosféricas/USP, São Paulo, Brasil, 162 pp. 
BELLIENI, G.; COMIN-CHIARAMONTI, P.; MARQUES, L.S.; MELFI, A.J.; NARDY, A.J.R.; PICCIRILO, E. M.; ROISENBERG, A. 1984. High- and low-TiO ${ }_{2}$ flood basalts from the Paraná plateau (Brazil): petrology and geochemical aspects bearing on their mantle origin. Neues Jahrbuch für Mineralogie 150, 273-306.

BIZZI, L.A.; SCHOBBENHAUS, C.; VIDOTTI, R.M.; GONÇALVES, J.H (Orgs.). 2003. Geologia, tectônica e recursos minerais do Brasil: texto, mapas \& SIG. Brasília: CPRM - Serviço Geológico do Brasil. 692 p.

BONVALOT, S.; BALMINO, G.; BRIAIS, A.; KUHN, M.; PEYREFITTE, A.; VALES, N.; BIANCALE, R.; GABALDA, G.; REINQUIN, F.; SARRAILH, M. 2012. World Gravity Map. Commission for the Geological Map of the World. Eds. BGI-CGMW-CNES-IRD, Paris.

BRITO NEVES, B.B.; FUCK, R.A.; CORDANI, U.G.; THOMAZ FILHO, A. 1984. Influence of basement structures on the evolution of the major sedimentary basins of Brazil. Journal of Geodynamics, 1: 495510.

CAMPOS NETO, M.C. 2000. Orogenic systems from southwestern Gondwana, an approach to Brasiliano-Pan African Cycle and orogenic collage in southeastern Brazil. In: CORDANI, U.G.; MILANI, E.J.; THOMAZ FILHO, A.; CAMPOS, D.A. (Eds.). Tectonic Evolution of South America. 31st International Geological Congress, Rio de Janeiro, Brazil, pp. 335-365.

CAMPOS NETO, M.C. \& BASEI, M.A.S. 1983. Evolução estrutural Brasiliana do Nordeste de São Paulo: dobramentos superpostos e esboço estratigráfico e tectônico. 4th Simpósio de Geologia Regional do Sudeste - SBG Núcleo S. Paulo, ATAS, pp. 61-72.

CAMPOS NETO, M.C. \& CABY, R. 2000. Terrane-accretion and upward extrusion of high-pressure granulites in the Neoproterozoic nappes of southeast Brazil: petrological and structural constraints. Tectonics, 19: 669-687.

CAMPOS NETO, M.C. \& FIGUEIREDO, M.C.H. 1995. The Rio Doce Orogeny, southeastern Brazil. J. S. Am. Earth Sci., 8, 143-162.

CARBOnELl, R.; LEVANDER, A.; KIND, R. 2013. The Mohorovičić discontinuity beneath the continental crust: An overview of seismic constraints. Tectonophysics, 609, 353-376.

CARVALHO, A.M.A.; VIDAL, A.C.; CHANG, H.K. 2011. Delimitação do embasamento da bacia de Taubaté. Revista do Instituto de Geociências - USP - São Paulo 11, 19-32.

ČERVENÝ, V. 2001. Seismic Ray Theory. Cambridge Univ. Press, Cambridge. 724 pp.

ČERVENÝ, V.; MOLOTKOV, I.A.; PŠENČÍK, I. 1977. Ray Method in Seismology. Charles Univ. Press, Praha. 214 pp.

CHAVES, C.A.M. 2014. Investigando o Manto sob a Província Magmática Paraná a partir de Inversão de Anomalias do Geoide e de Tempos de Atraso da Onda P. Tese (Doutorado em Geofísica). Instituto de Astronomia, Geofísica e Ciências Atmosféricas, Universidade de São Paulo. 176 p.

CHRISTENSEN, N.I. 1996. Poisson's ratio and crustal seismology. Journal of Geophysical Research, Vol. 101, No. B2, 3139-3156.

CHRISTENSEN, N.I. \& MOONEY, W.D. 1995. Seismic velocity structure and composition of the continental crust: A global view. Journal of Geophysical Research, Vol. 100, n. B7, p. 9761-9788.

COBBOLD, P.R.; MEISLING, K.E.; MOUNT, V.S. 2001. Reactivation of an obliquely rifted margin, Campos and Santos Basins, southeastern Brazil. American Association of Petroleum Geologists Bulletin 85, 19251944.

COGNÉ, N.; GALLAGHER, K.; COBBOLD, P.R. 2011. Post-rift reactivation of the onshore margin of southeast Brazil: Evidence from apatite (U-Th)/He and fission-track data. Earth and Planetary Science Letters, 309. p. $118-130$. 
COGNÉ N.; COBBOLD, P.R.; RICCOMINI, C.; GALLAGHER, K. 2013. Tectonic setting of the Taubaté Basin (Southeastern Brazil): Insights from regional seismic profiles and outcrop data. Journal of South American Earth Sciences, vol. 42. pp. 194-204.

COHEN, K.M.; FINNEY, S.C.; GIBBARD, P.L.; FAN, J.-X. 2013; updated. The ICS International Chronostratigraphic Chart. Episodes 36: 199-204.

COOK, F.A.; WHITE, D.J.; JONES, A.G.; EATON, D.W.S.; HALL, J.; CLOWES, R.M. 2002. How the crust meets the mantle: Lithoprobe perspectives on the Mohorovičić discontinuity and crust-mantle transition. Canadian Journal of Earth Sciences, 47: 315-351.

CORDANI, U.G.; BRITO NEVES, B.B.; FUCK, R.A.; THOMAZ FILHO, A.; CUNHA, F.M.B. 1984. Estudo Preliminar de integração do Pré-Cambriano com os eventos tectônicos das Bacias Sedimentares Brasileiras. Revista Ciência Técnica-Petróleo. Sessão de Exploração de Petróleo. Petrobrás/CENPES/Sintep, Publ. 15, 70 p.

DARDENNE, M.A. 2000. The Brasilia Fold Belt. In: CORDANI, U. G.; MILANI, E. J.; THOMAZ FILHO, A.; CAMPOS, D. A. (Org.). Tectonic Evolution of South America. 1st Ed. Rio de Janeiro: Brazil, p. 231263.

EIRADO, L.G.; HEILBRON, M.; ALMEIDA, J.C.H. 2006. Os terrenos tectônicos da Faixa Ribeira na Serra da Bocaina e na Baía da Ilha Grande, sudeste do Brasil. Revista Brasileira de Geociências 36, 426-436.

ENDERLE, U.; TITTGEMEYER, M.; ITZIN, M.; PRODEHL, C.; FUCHS, K. 1997. Scales of structure in the lithosphere - images of processes. In: FUCHS, K.; ALTHERR, R.; MÜLLER, B.; PRODEHL, C. (Eds.). Stress and stress release in the lithosphere - structure and dynamic processes in the rifts of western Europe: Tectonophysics, v. 275, p. 165-198.

ERNESTO, M.; MARQUES, L.S.; PICCIRILlO, E.M.; MOLINA, E.C.; USSAMI, N.; COMINCHIARAMONTI, P.; BELLIENI, G., 2002. Paraná Magmatic Province-Tristan da Cunha plume system: fixed versus mobile plume, petrogenetic considerations and alternative heat sources. Journal of Volcanology and Geothermal Research 118, 15-36.

EVAIN, M.; AFILHADO, A.; RIGOTI, C.; LOUREIRO, A.; ALVES, D.; KLINGELHOEFER, F.; SCHNURLE, P.; FELD, A.; FUCK, R.A.; SOARES, J.E.P.; LIMA, M.V.A.G.; CORELA, C.; MATIAS, L.; BENABDELlOUAHED, M.; BALTZER, A.; RABINEAU, M.; VIANA, A.; MOULIN, M. \& ASLANIAN, D. 2015. Deep structure of the Santos Basin-São Paulo Plateau System, SE Brazil. J. Geophys. Res.: Solid Earth, 120. 31 p. doi:10.1002/2014JB011561.

FENG, M.; ASSUMPÇÃO, M.; VAN DER LEE, S. 2004. Group-velocity tomography and lithospheric S-velocity structure of the South American continent. Physics of the Earth and Planetary Interiors, 147, 315-331.

FUCK, R.A.; PIMENTEL, M.M.; SILVA, L.J.H.D. 1994. Compartimentação tectônica da porção oriental da Província Tocantins (Extended Abstract). Congresso Brasileiro de Geologia, 38, Camboriú, Brasil, SBG, vol. 1, pp. 215-216.

FUCK, R.A.; PIMENTEL, M.M.; SOARES, J.E.P.; DANTAS, E.L. 2005. Compartimentação da Faixa Brasília. In: IX Simpósio de Geologia do Centro-Oeste. Goiânia. p. 26-27.

FÚLFARO, V.J.; SAAD, A.R.; SANTOS, M.V.; VIANNA, R.B. 1982. Compartimentação e evolução tectônica da Bacia do Paraná. Revista Brasileira de Geociências, São Paulo, v. 12, n. 4, p. 233-256.

FRANÇA, G.S. \& ASSUMPÇÃO, M. 2004 .Crustal structure of the Ribeira fold belt, SE Brazil, derived from receiver functions. Journal of South American Earth Sciences, v. 16, n.8, p. 743-758.

FRANCO-MAGALHÃES, A.O.B.; CUGLIERI, M.A.A.; HACKSPACHER, P.C.; SAAD, A.R. 2014. Long-term landscape evolution and post-rift reactivation in the southeastern Brazilian passive continental margin: Taubaté basin. Int. J. Earth Sci. (Geol. Rundsch.), 103: 441-453. 
GERYA, T. \& BURG, J.P. 2007. Intrusion of ultramafic magmatic bodies into the continental crust: Numerical simulation. Physics of the Earth and Planetary Interiors, 160. p. 124-142.

GLADCZENKO, T.P.; HINZ, K.; ELDHOLM, O.; MEYER, H.; NEBEN, S.; SKOGSEID, J. 1997. South Atlantic volcanic margins. Geological Society of London Journal, v. 154, p. 465-470.

GONTIJO-PASCUTTI, A.H.F.; HASUI, Y.; SANTOS, M.; SOARES JÚNIOR, A.V.; SOUZA, I.A. 2012. As serras do Mar e da Mantiqueira. In: HASUI, Y.; CARNEIRO, C.D.R.; ALMEIDA, F.F.M.; BARTORELLI, A. (Eds.). Geologia do Brasil. São Paulo: Beca. 900 p.

GREEN, R. 1974. The seismic refraction method - A review. Geoexploration, 12, p. 259-284.

HACKSPACHER, P.C.; SAAD, A.R.; RIBEIRO, M.C.S.; GODOY, D.F.; HADLER NETO, J.C. 2008. Tectonic reactivation of the South Atlantic margin, Southeastern Brazil, during the Paleogene time: apatite fission track analysis and U-Th/He systematics. In: GARVER, J.I. \& MONTARIO, M.J. (Eds.). Proceedings from the 11th International Conference on Thermochronometry, Anchorage, Alaska. 3 p.

HAMZA, V.M. \& MUÑOZ, M. 1996. Heat flow map of South America. Geothermics, 25(6): 599-621.

HEILBRON, M. \& MACHADO, N. 2003. Timing of terrane accretion in the Neoproterozoic-Eopaleozoic Ribeira orogen (SE Brazil). Precambrian Research 125, 87-112.

HEILBRON, M.; PEDROSA-SOARES, A.C.; CAMPOS NETO, M.C.; SILVA, L.C.; TROUW, R.A.J.; JANASI, V.A. 2004. Província Mantiqueira. In: MANTESSO NETO, V.; BARTORELLI, A.; CARNEIRO, C.D.R.; BRITO NEVES, B.B. (Eds.). Geologia do Continente Sul-Americano: Evolução da Obra de Fernando Flávio Marques de Almeida. Ed. Beca, São Paulo, pp. 203-235.

HEILBRON, M.; VALERIANO, C.M.; TASSINARI, C.C.G.; ALMEIDA, J.C.H.; TUPINAMBÁ, M.; SIGA JR., O.; TROUW, R.A.J. 2008. Correlation of Neoproterozoic terranes between the Ribeira Belt, SE Brazil and its African counterpart: comparative tectonic evolution and open questions. In: PANKHURST, R.J.; TROUW, R.A. J.; BRITO NEVES, B.B. \& DE WIT, M. (Eds.). West Gondwana Pre-Cenozoic Correlations across the South Atlantic Region, Journal Geological Society London, Special Publication, vol. 294, pp. 211-232.

HOWELL, D.G. 1989. Tectonic of suspect terranes: Mountain building and continental growth. Chapman Hall (Eds.), London, 232 p.

HURTER, S.J. \& POLLACK, H.N. 1996. Terrestrial heat flow in the Paraná Basin, southern Brazil. Journal of Geophysical Research, 101, 8659-8671.

JULIÀ, J.; ASSUMPÇÃO, M.; ROCHA, M.P. 2008. Deep crustal structure of the Paraná Basin from receiver functions and Rayleigh-wave dispersion: Evidence for a fragmented cratonic root. Journal of Geophysical Research, v. 113, p. B08318.

KABAN, M.K.; SCHWINTZER, P.; ARTEMIEVA, I.M.; MOONEY, W.D. 2003. Density of the continental roots: compositional and thermal contributions. Earth and Planetary Science Letters, 209. p. 53-69.

KING, S.D. \& ANDERSON, D.L. 1998. Edge-driven convection. Earth and Planetary Science Letters, 160:289296.

KLEIN, G.D. 1995. Intracratonic basins. In: BUSBY, C.J. \& INGERSOLL, R.V. (Eds.): Tectonics of Sedimentary Basins. Blackwell, Oxford, p. 459-478.

LEONARDOS, O.H. \& FYFE W.S. 1974. Ancient metamorphic-migmatite belts of the Brazilian Atlantic coast: the African connection. Revista Brasileira de Geociências, 4:247-251.

LIMA, M.V.A G. 2011. Emprego do método de refração sísmica profunda para a determinação da estrutura crustal da Zona Transversal da Província Borborema, Nordeste do Brasil. Tese de Doutorado. Instituto de Astronomia, Geofísica e Ciências Atmosféricas, Universidade de São Paulo: São Paulo. 91 p. 
LIMA, M.V.A.G.; BERROCAL, J.; SOARES, J.E.P.; FUCK, R.A. 2015. Deep seismic refraction experiment in northeast Brazil: New constraints for Borborema province evolution. Journal of South American Earth Sciences, 58, p. 335-349.

LOWRY, A.R. \& PÉREZ-GUSSINYÉ, M. 2011. The role of crustal quartz in controlling Cordilleran deformation. Nature, Vol. 471, 353-357.

QUINTAS, M.C.L. 1995. O embasamento da Bacia do Paraná: reconstrução geofísica de seu arcabouço. Tese de Doutorado, Instituto de Astronomia, Geofísica e Ciências Atmosféricas, Universidade de São Paulo, S. Paulo, 218 p.

QUINTAS, M.C.L.; MANTOVANI, M.S.M.; ZALÁN, P.V. 1997. Contribution to the study of the mechanical evolution of the Paraná Basin. B. Geoci. Petrobras, Rio de Janeiro, 11 (1/2): 48-73.

QUINTAS, M.C.L.; MANTOVANI, M.S.M.; ZALÁN, P.V. 1999. Contribuição ao estudo da evolução mecânica da Bacia do Paraná. Revista Brasileira de Geociências, 29(2): 217-226.

MACEDO, J.M. 1991. Evolução tectônica da Bacia de Santos e áreas continentais adjacentes. In: GABAGLIA, G.P.R. \& MILANI, E.J. (Eds.). Origem e evolução de bacias sedimentares. Rio de Janeiro. PETROBRÁS. p. 361-374.

MANTOVANI, M.S.M. \& BRITO NEVES, B.B. 2009. The Paranapanema Lithospheric block: its nature and role in the accretion of Gondwana. In: GAUCHER, C.; SIAL, A.N.; HALVERSON, G.P.; FRIMMEL, H.E. (Org.). Neoproterozoic-Cambrian Tectonics, global Change and Evolution - a focus on southwestern Gondwana. Amsterdam: Elsevier, v. 1, p. 257-272.

MANTOVANI, M.S.M.; QUINTAS, M.C.L.; SHUKOWSKY, W.; BRITO NEVES, B.B. 2005. Delimitation of the Paranapanema Proterozoic Block: a geophysical contribution. Episodes, 28: 18-22.

MARIANI, P.; BRAITENBERG, C.; USSAMI, N. 2013. Explaining the thick crust in Paraná basin, Brazil, with satellite GOCE gravity observations. Journal of South American Earth Sciences, Vol. 45, p. 209.-223.

MARQUES, A. 1990. Evolução tectono-sedimentar e perspectivas exploratórias da Bacia de Taubaté, São Paulo, Brasil. Boletim de Geociências da Petrobrás 4, n. 1, p. 221-240.

MARQUES, A.; ZANOTTO, O.A.; FRANÇA, A.B; ASTOLFI, M.A.M.; DE PAULA, O.B. 1993. Compartimentação tectônica da Bacia do Paraná. PETROBRAS - Núcleo de Exploração da Bacia do Paraná, Curitiba, 87 p. (Relatório interno).

MAUS, S. 2009. EMAG2: Earth Magnetic Anomaly Grid (2-arc-minute resolution). National Geophysical Data Center, NOAA. Model. doi:10.7289/V5MW2F2P.

MEISSNER, R. 1973. The Moho as a transition zone. Geophysical Surveys, Vol. 1, Issue 2. Kluwer Academic Publishers, pp. 195-216.

MILANI, E.J. 1997. Evolução Tectono-estratigráfica da Bacia do Paraná e seu relacionamento com a Geodinâmica Fanerozóica do Gondwana Ocidental. Tese de Doutorado, Universidade Federal do Rio Grande do Sul, Porto Alegre, RS, 255 p.

MILANI, E.J. 2004. Comentários sobre a origem e evolução tectônica da Bacia do Paraná. In: MANTESSO NETO, V.; BARTORELlI, A.; CARNEIRO, C.D.R.; BRITO NEVES, B.B. (Eds.). Geologia do Continente Sul-Americano: Evolução da Obra de Fernando Flávio Marques de Almeida. Ed. Beca, São Paulo, pp. 265-279.

MILANI, E.J.; MELO, J.H.G.; SOUZA, P.A.; FERNANDES, L.A.; FRANÇA, A.B. 2007. Bacia do Paraná, Bol. de Geociências da Petrobrás, 15(2), 265-287.

MILANI, E.J. \& RAMOS, V.A. 1998. Orogenias paleozoicas no domínio sul-ocidental do Gondwana e o ciclos de subsidência da Bacia do Paraná. Revista Brasileira de Geociências, 28(4), p. 527-544. 
MINEI, C.O. 2015. Imageamento Crustal e Litosférico no Nordeste da Bacia do Paraná por Sondagens Magnetotelúricas. Dissertação (Mestrado em Geofísica). Instituto de Astronomia, Geofísica e Ciências Atmosféricas, Universidade de São Paulo. 61 p.

MIZUSAKI, A.M.P. 1989. Análise petrográfica e datação radiométrica do poço 2-Tl-1-MS (testemunhos 39 e 40). PETROBRAS-CENPES, Rio de Janeiro. 8 p. (Relatório interno).

MOHOROVIČIĆ, A. 1910. Potres od 8.X 1909. (Das Beben vom 8.X. 1909.), Jahrbuch des meteorologischen Observatoriums in Zagreb (Agram) für das Jahr 1909, 1-56 (English translation, 1992. Earthquake of 1909 October 8). Geofizika 9, 3-55.

MOULIN, M.; ASLANIAN, D.; UNTERNHER, P., 2010. A new starting point for the South and Equatorial Atlantic Ocean, Earth-Sci. Rev., 98, 1-37.

MUSACCHIO, G.; MOONEY, W.D.; LUETGERT, J.H.; CHRISTENSEN, N.I. 1997. Composition of the crust in the Grenville and Appalachian Provinces of North America inferred from $\mathrm{Vp} / \mathrm{Vs}$ ratios. Journal of Geophysical Research, 102, 15225-15241.

NIELSEN, C. \& THYBO, H. 2009. Lower crustal intrusions beneath the southern Baikal Rift Zone: evidence from full-waveform modelling of wide-angle seismic data. Tectonophysics 470, 298-318.

OLIVEIRA, L.O.A. 1987. Aspectos da evolução termomecânica da Bacia do Paraná no Brasil. Dissertação de Mestrado. Universidade Federal de Ouro Preto, Escola de Minas, Departamento de Geologia, 179 p.

PACIULLO, F.V.P.; RIBEIRO, A.; ANDREIS, R.R.; TROUW, R.A.J. 2000. The Andrelândia Basin, a neoproterozoic intraplate continental margin, southern Brasília belt, Brazil. Revista Brasileira de Geociências 30, 200-202.

PADILHA, A.L.; VITORELLO, Í.; ANTUNES, C.E.; PÁDUA, M.B. 2015. Imaging three-dimensional crustal conductivity structures reflecting continental flood basalt effects hidden beneath thick intracratonic sedimentary basin. Journal of Geophysical Research, v. 120, n. 7, p. 4702-4719. doi: 10.1002/2014JB011657.

PEATE, D.W.; HAWKESWORTH, C.J.; MANTOVANI, M.S.M. 1992. Chemical stratigraphy of the Paraná lavas, South America: classification of magma types and their spatial distribution. Bulletin of Volcanology 55, 119-139.

PEIXOTO, C.L.O. 2015. Caracterização sismológica da crosta sob o perfil PABBRISE: uma aproximação por função do receptor e razão espectral H/V. Dissertação (Mestrado). Instituto de Geociências, Universidade de Brasília, Brasília.

PERROTTA, M.M.; SALVADOR, E.D.; LOPES, R.C.; D’AGOSTINO, L.Z.; PERUFFO, N.; GOMES, S.D.; SACHS, L.L.B.; MEIRA, V.T.; GARCIA, M.G.M.; LACERDA FILHO, J.V. 2005. Mapa Geológico do Estado de São Paulo, escala 1:750.00. Programa Geologia do Brasil - PGB, Serviço Geológico do Brasil, São Paulo.

PETERNEL, R.; TROUW, R.A.J., SCHMITT, R. 2005. Interferência entre duas faixas móveis neoproterozóicas: o caso das faixas Brasília e Ribeira, no sudeste do Brasil. Revista Brasileira de Geociências 35, 297-310.

PIMENTEL, M.M.; DARDENNE, M.A.; FUCK, R.A.; VIANA, M.G.; JUNGES, S.L.; FISCHEL, D.P.; SEER, H.J.; DANTAS, E.L. 2001. Nd isotopes and the provenance of the detrital sediments of the Neoproterozoic Brasília Belt, central Brazil. Journal of South American Earth Sciences, 14, 571-585.

PIMENTEL, M.M.; FUCK, R.A.; ALVARENGA, C.J.S. 1996. Post-Brasiliano (Pan-African) high-K granitic magmatism in central Brazil: The role of late Precambrian-early Paleozoic extension, Precambrian Res., 80, 217-238. 
PIMENTEL, M.M.; FUCK, R.A.; JOST, H.; FERREIRA FILHO, C.F.; ARAÚJO, S. 2000. The basement of the Brasília Fold Belt and the Goiás Magmatic Arc. In: CORDANI, U.G.; MILANI, E.J.; THOMAZ FILHO, A.; CAMPOS, D.A. (Org.). The Tectonic Evolution of South America. Rio de Janeiro: 31. IGC, p. 195229.

PIUZANA, D.; PIMENTEL, M.M.; FUCK, R.A.; ARMSTRONG, R. 2003. SHRIMP U-Pb and Sm-Nd data from the Araxá Group and associated magmatic rocks: constraints for the age of sedimentation and geodynamic context of the southern Brasília Belt, central Brazil. Precambrian Research, 125, 139-160.

PLANKE, S. \& CAMBRAY, H. 1998. Seismic properties of flood basalts from Hole 917A downhole data, Southeast Greenland Volcanic Margin. In: SAUNDERS, A.D.; LARSEN, H.C.; \& WISE, S.W., JR. (Eds.). Proceedings of the Ocean Drilling Program, Scientific Results, Vol. 152: College Station, TX (Ocean Drilling Program). p. 453-462.

PRODEHL, C.; KENNETT, B.; ARTEMIEVA, I.; THYBO, H. 2013. 100 years of seismic research on the Moho. Tectonophysics, vol. 609, pp. 9-44.

PRODEHL, C. \& MOONEY, W.D. 2012. Exploring the Earth's crust - history and results of controlled-source seismology. Geological Society of America Memoir, 208. pp. 764. http:// dx.doi.org/10.1130/2012.2208.

RAWLINSON, N.; HAUSER, J.; SAMBRIDGE, M. 2008. Seismic ray tracing and wavefront tracking in laterally heterogeneous media. In: DMOWSKA, R. (Editor). Advances in Geophysics, Volume 49, Elsevier. p 203-273.

RENNE, P.R.; DECKART, K.; ERNESTO, M.; FÉRAUD, G.; PICCIRILLO, E.M. 1996, Age of the Ponta Grossa dike swarm (Brazil), and implications to Paraná flood volcanism: Earth and Planetary Science Letters, v. 144, p. 199-211.

RICCOMINI, C. 1989. O Rift Continental do Sudeste do Brasil. Tese de Doutorado, Instituto de Geociências, Universidade de São Paulo, p. 256.

RICCOMINI, C.; SANT’ANNA, L.G.; FERRARI, A.L. 2004. Evolução geológica do rift continental do Sudeste do Brasil. In: MANTESSO-NETO, V.; BARTORELLI, A.; CARNEIRO, C.D.R.; BRITO NEVES, B.B. (Eds.). Geologia do continente Sul-Americano: evolução da obra de Fernando Flávio Marques de Almeida. São Paulo: Beca. p. 383-405.

RINGWOOD, A.E. \& GREEN, D. H. 1966. An experimental investigation of the Gabbro-Eclogite transformation and some geophysical implications. Tectonophysics, Vol. 3, Issue 5, p. 383-427.

ROCHA, M.P.; SCHIMMEL, M.; ASSUMPÇÃO, M. 2011. Upper-mantle seismic structure beneath SE and Central Brazil from P- and S-wave regional traveltime tomography. Geophysical Journal International, v. 184, p. 268-286.

ROCHA-JÚNIOR, E.R.V.; MARQUES, L.S.; BABINSKY, M.; NARDY, A.J.R.; FIGUEIREDO, A.M.G.; MACHADO, F.B. 2013. Sr-Nd-Pb isotopic constraints on the nature of the mantle sources involved in the genesis of the high-Ti tholeiites from northern Paraná Continental Flood Basalts (Brazil). Journal of South American Earth Sciences 46, 9-25.

ROCHA-JÚNIOR, E.R.V.; PUCHTEL, I.S.; MARQUES, L.S.; WALKER, R.J.; MACHADO, F.B.; NARDY, A.J.R.; BABINSKI, M.; FIGUEIREDO, A.M.G. 2012. Re-Os isotope and highly siderophile element systematics of the Paraná Continental Flood Basalts (Brazil). Earth and Planetary Science Letters 337$338,164-173$.

RUMPFHUBER, E. 2008. An Integrated Analysis of Controlled and Passive Source Seismic Data. PhD thesis. Faculty of Graduate School, University of Texas: El Paso. 105 p.

RUPPERT, S.; FLIEDNER, M.M.; ZANDT, G. 1998. Thin crust and active upper mantle beneath the Southern Sierra Nevada in the Western United States. Tectonophysics, 286, 237-252. 
SANDRIN, A.; NIELSEN, L.; THYBO, H. 2009. Layered crust-mantle transition zone below a large crustal intrusion in the Norwegian-Danish Basin. Tectonophysics 472, p. 194-212.

SCHMITT, R.S.; TROUW, R.A.J.; VAN SCHMUS, W.R.; PIMENTEL, M.M. 2004. Late amalgamation in the central part of Western Gondwana: new geochronological data and the characterization of a Cambrian collision orogeny in the Ribeira Belt (SE Brazil). Precambrian Research 133, 29-61.

SHEARER, P.M. 2009. Introduction to Seismology. 2nd Edition. Cambridge University Press, Cambridge. 409 p.

SOARES, J.E.P. 2005. Estudos de refração sísmica profunda, função do receptor e gravimetria na Província Tocantins, Brasil central. Instituto de Geociências, Universidade de Brasília. Tese de doutorado, n. 73. Brasília. p. 128.

SOARES, J.E.P.; BERROCAL, J.A.; FUCK, R.A.; MOONEY, W.D.; VENTURA, D.B.R. 2006. Seismic characteristics of central Brazil crust and upper mantle: A deep seismic refraction study. Journal of Geophysical Research, v. 111, p. 302-333.

SOARES, P.C. 1991. Tectônica sinsedimentar cíclica na Bacia do Paraná: controles. Tese para provimento de vaga de Professor Titular, Universidade Federal do Paraná, Curitiba, 131 p.

STAROSTENKO, V.; JANIK, T; KOLOMIYETS, K.; CZUBA, W.; ŚRODA, P.; GRAD, M.; KOVÁCS, I.; STEPHENSON, R.; LYSYNCHUK, D.; THYBO, H.; ARTEMIEVA, I.M.; OMELCHENKO, V.; GINTOV, O.; KUTAS, R.; GRYN, D.; GUTERCH, A.; HEGEDÜS, E.; KOMMINAHO, K.; LEGOSTAEVA, O.; TIIRA, T.; TOLKUNOV, A. 2013. Seismic velocity model of the crust and upper mantle along profile PANCAKE across the Carpathians between the Pannonian Basin and the East European Craton. Tectonophysics, 608, p. 1049-1072.

STEWART, K.; TURNER, S.; KELLEY, S.; HAWKESWORTH, C.; KIRSTEIN, L.; MANTOVANI, M. 1996. $3-\mathrm{D},{ }^{40} \mathrm{Ar}-{ }^{39} \mathrm{Ar}$ geochronology in the Paraná continental flood basalt province: Earth and Planetary Science Letters, v. 143, p. 95-109.

TAVARES, E.J. 2014. Determinação da razão de Poisson da crosta e manto litosférico sob a linha de refração sísmica profunda NW-SE da Província Borborema. Dissertação (Mestrado). Instituto de Geociências, Universidade de Brasília, Brasília. 87 f.

THIEDE, D.S. \& VASCONCELOS, P.M. 2010. Paraná flood basalts: rapid extrusion hypothesis confirmed by new ${ }^{40} \mathrm{Ar} /{ }^{39} \mathrm{Ar}$ results. Geology, 38 (8), 747-750.

THYBO, H. \& ARTEMIEVA, I.M. 2013. Moho and magmatic underplating in continental lithosphere. Tectonophysics, 609, 605-619.

THYBO, H. \& NIELSEN, C.A. 2012. Seismic velocity structure of crustal intrusions in the Danish Basin. Tectonophysics, 572, 64-75.

TRINDADE, C.R. 2014. Espessura crustal e Razão de Poisson do Brasil Central: uma aproximação por função do receptor. Dissertação (Mestrado). Instituto de Geociências, Universidade de Brasília, Brasília. 90 f.

TROUW, R.A.J.; HEILBRON, M.; RIBEIRO, A.; PACIULLO, F.; VALERIANO, C.M.; ALMEIDA, J.C.H.; TUPINAMBÁ, M.; ANDREIS, R.R. 2000. The central segment of the Ribeira Belt. In: CORDANI, U.G.; MILANI, E.J.; THOMAZ FILHO, A.; CAMPOS, D.A. (Eds.). Tectonic Evolution of South America, pp. 355-365.

TROUW, R.A.J.; PETERNEL, R.; RIBEIRO, A.; HEILBRON, M.; VINAGRE, R.; DUFFLES, P.; TROUW, C. C.; FONTAINHA, M.; KUSSAMA, H. 2013. A new interpretation for the interference zone between the southern Brasília Belt and the Central Ribeira Belt, SE Brazil. J. South Am. Earth Sci. 48, 43-57 p.

TUPINAMBÁ, M.; TEIXEIRA, W.; HEILBRON, M. 2000. Neoproterozoic Western Gondwana assembly and subduction related plutonism: the role of the Rio Negro Complex in the Ribeira Belt, southeastern Brazil. Revista Brasileira de Geociências 30, 7-11. 
TURNER, S.; REGELOUS, M.; KELLEY, S.; HAWKESWORTH, C.; MANTOVANI, M. 1994. Magmatism and continental break-up in the South Atlantic: High precision 40Ar-39Ar geochronology: Earth and Planetary Science Letters, v. 121, p. 333-348.

TÖPFNER, C. 1996. Brasiliano-Granitoide in den Bundesstaaten São Paulo und Minas Gerais- eine vergleichende Studie. Münchner Geologische Hefte, v. A17, p. 1-258.

VAIL, P.R.; MITCHUM, R.M.; THOMPSON, S. 1977. Seismic stratigraphy and global changes of sea level, part 3: relative changes of sea level from coastal onlap. In: PAYTON, C.E. (Ed.). Seismic stratigraphy: applications to hydrocarbon exploration. AAPG Memoir, 26. Tulsa: American Association of Petroleum Geologists. p. 63-81.

VALERIANO, C.M.; PIMENTEL, M.M.; HEILBRON, M.; TROUW, R.A.J.; ALMEIDA, J.C.H. 2008. Tectonic evolution of the Brasília Belt, Central Brazil, and early assembly of Gondwana. In: PANKHURST, R.J.; TROUW, R.A.J.; BRITO NEVES, B.B.; DE WIT, M.J. (Eds.). West Gondwana: Pre-Cenozoic Correlations across the South Atlantic Region, Geological Society of London, Special Publications, vol. 294, pp. 197-210.

VALERIANO, C.M; TUPINAMBÁ, M.; SIMONETTI, A.; HEILBRON, M.; ALMEIDA, J.C.H.; EIRADO, L. G. 2011. U-Pb LA-MC-ICPMS geochronology of Cambro-Ordovician post-collisional granites of the Ribeira belt, southeast Brazil: Terminal Brasiliano magmatism in central Gondwana supercontinent. Journal of South American Earth Sciences, Volume 32, Issue 4, p. 416-428.

VLACH, S.R.F. 2001. Microprobe monazite constraints for an early (ca. 790 Ma) Brasiliano orogeny: the Embú Terrane, Southeastern Brazil. In: Sernageomin, III Simposio Sudamericano en Geología Isotópica, Pucón, pp. 265-268. Extended Abstracts, (CD-ROM).

WOLDEMICHAEL, S.F. 2003. Estruturas geoelétricas crustais da Bacia do Pantanal e Faixa Paraguai: implicações tectônicas. Tese de Doutorado, Instituto de Astronomia, Geofísica e Ciências Atmosféricas, Universidade de São Paulo, 189 p.

ZALÁN, P.V. 2012. Origem e evolução das bacias cenozóicas do Sudeste. In: HASUI, Y.; CARNEIRO, C.D.R.; ALMEIDA, F.F.M.; BARTORELLI, A. (Eds.). Geologia do Brasil. São Paulo: Beca. 900 p.

ZALÁN, P.V. \& OLIVEIRA, J.A.B. 2005. Origem e evolução estrutural do sistema de rifte Cenozóicos do Sudeste do Brasil. Boletim de Geociências da Petrobras, 13, n.2, p. 269-300.

ZALÁN, P.V.; WOLFF, S.; ASTOLFI, M.A.M.; VIEIRA, I.S.; CONCEIÇÃO, J.C.J.; APPI, V.T.; SANTOS NETO, E.V.; CERQUEIRA, J.R.; MARQUES, A. 1990. The Paraná Basin, Brazil. In: LEIGHTON, M.W.; KOLATA, D.R.; OLTZ, D.F.; EIDEL, J.J. (Eds.). Interior cratonic basins. AAPG Memoir, 51. Tulsa: American Association of Petroleum Geologists, p. 681-708.

ZALÁN, P.V.; WOLFF, S.; CONCEIÇÃO, J.C.J.; MARQUES, A.; ASTOLFI, M.A.M.; VIEIRA, I.S.; APPI, V.T.; ZANOTTO, O.A. 1991. Bacia do Paraná. In: GABAGLIA, G.P.R. \& MILANI, E.J. (Coords.) Origem e Evolução de Bacias Sedimentares. PETROBRÁS. Rio de Janeiro: Ed. Gávea. p. 135-164.

ZELT, C.A. 1999. Modelling strategies and model assessment for wide-angle seismic traveltime data. Geophysical Journal International, 139: 183-204. doi: 10.1046/j.1365-246X.1999.00934.x.

ZELT, C.A. \& ELLIS, R.M. 1988. Practical and efficient ray tracing in two-dimensional media for rapid traveltime and amplitude forward modelling, Canadian Journal of Exploration Geophysics, 24, 16-31.

ZELT, C.A. \& SMITH, R.B. 1992. Seismic travel-time inversion for 2-D crustal velocity structure. Geophysical International Journal, 108, 16-34. 